Andrews University

Digital Commons @ Andrews University

\title{
Measuring The Perceived Effectiveness Of Five Selected Professional Courses Taken By Alumni Theology Majors And How They Are Related To Selective Demographics: A Mixed Methods Study
}

Barry J. Tryon

Andrews University, tryonb@andrews.edu

Follow this and additional works at: https://digitalcommons.andrews.edu/dissertations

Part of the Educational Assessment, Evaluation, and Research Commons, Higher Education Commons, and the Practical Theology Commons

\section{Recommended Citation}

Tryon, Barry J., "Measuring The Perceived Effectiveness Of Five Selected Professional Courses Taken By Alumni Theology Majors And How They Are Related To Selective Demographics: A Mixed Methods Study" (2017). Dissertations. 1644.

https://digitalcommons.andrews.edu/dissertations/1644

https://dx.doi.org/10.32597/dissertations/1644

This Dissertation is brought to you for free and open access by the Graduate Research at Digital Commons @ Andrews University. It has been accepted for inclusion in Dissertations by an authorized administrator of Digital Commons@ Andrews University. For more information, please contact repository@andrews.edu. 


\begin{abstract}
MEASURING THE PERCEIVED EFFECTIVENESS OF FIVE SELECTED PROFESSIONAL COURSES TAKEN BY ALUMNI THEOLOGY MAJORS AND HOW THEY ARE RELATED TO SELECTIVE DEMOGRAPHICS: A MIXED METHODS STUDY
\end{abstract}

by

Barry J. Tryon

Chair: Erich W. Baumgartner, Ph.D. 


\title{
ABSTRACT OF GRADUATE STUDENT RESEARCH
}

\author{
Dissertation
}

\author{
Andrews University \\ School of Education
}

\section{Title: MEASURING THE PERCEIVED EFFECTIVENESS OF FIVE SELECTED PROFESSIONAL COURSES TAKEN BY ALUMNI THEOLOGY MAJORS AND HOW THEY ARE RELATED TO SELECTIVE DEMOGRAPHICS: A MIXED METHODS STUDY}

Name of researcher: Barry Tryon

Name and degree of faculty chair: Erich W. Baumgartner, Ph.D.

Date completed: July 2017

\section{Problem}

The study was prompted by the need for the evaluation of current theological educational programs for preparing students to meet the many challenges of pastoral ministry in a rapidly changing world. However, to date there has been little published research addressing the effectiveness of undergraduate theological education. Furthermore, changes implemented in the theological education program at Southern Adventist University (Southern) have not been evaluated for their effectiveness for ministerial job preparedness. 


\section{Method}

This descriptive study measured the perceived effectiveness of five professional courses taught in the undergraduate theological educational program at Southern for ministerial job preparedness. A parallel mixed methods design, same sample, involved collecting a multiple-question survey with both Likert-style and open-ended questions from a convenience sample of Southern theology alumni. In addition, data from exit interviews conducted by the Dean of the School of Religion were reviewed for predictors of perceived effectiveness for ministerial job preparedness. Descriptive and inferential statistical analysis, posteriori word coding, and thematic analysis were used to analyze the data.

\section{Results}

Eighty-one percent of theology alumni surveyed indicated that the education they received at Southern equipped them for ministry. The alumni responses identified several positive aspects of the current theological educational program at Southern, including hands-on, practical components, and courses taught by professors experienced in pastoral ministry. Suggestions for improvement included condensing the Personal Evangelism course to one semester, and the addition of lectures or courses on conflict resolution and basic counseling skills.

\section{Conclusion}

The findings suggest that Southern is effectively preparing its theology majors for pastoral ministry through the five professional courses studied in this research. It is 
recommended that regular alumni surveys be conducted as part of curricula development and evaluation. 
Andrews University

School of Education

\title{
MEASURING THE PERCEIVED EFFECTIVENESS OF FIVE SELECTED PROFESSIONAL COURSES TAKEN BY ALUMNI THEOLOGY MAJORS AND HOW THEY ARE RELATED TO SELECTIVE DEMOGRAPHICS: A MIXED METHODS STUDY
}

\author{
A Dissertation \\ Presented in Partial Fulfillment \\ of the Requirements for the Degree \\ Doctor of Philosophy
}

by

Barry J. Tryon

July 2017 
CCopyright by Barry J. Tryon 2017 All Rights Reserved 


\title{
MEASURING THE PERCEIVED EFFECTIVENESS OF FIVE SELECTED PROFESSIONAL COURSES TAKEN BY ALUMNI THEOLOGY MAJORS AND HOW THEY ARE RELATED TO SELECTIVE DEMOGRAPHICS: A MIXED METHODS STUDY
}

\author{
A dissertation \\ presented in partial fulfillment \\ of the requirements for the degree \\ Doctor of Philosophy
}

by

Barry J. Tryon

APPROVAL BY THE COMMITTEE:

Chair: Erich W. Baumgartner

Member: Stanley Patterson

Member: Isadore Newman

External Examiner: Boubakar Sanou
Dean, School of Education

Robson Marinho 
To Lilly,

my life companion,

whose love, encouragement and support helped me to believe

this could be successfully completed. 


\section{TABLE OF CONTENTS}

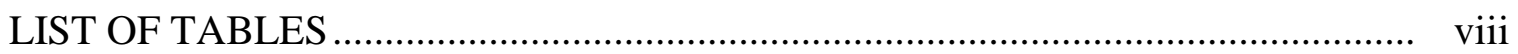

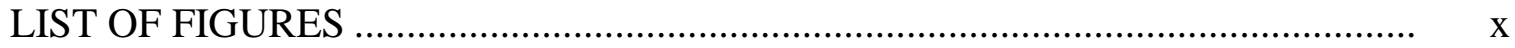

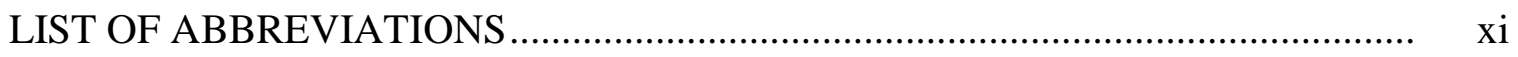

ACKNOWLEDGEMENTS ............................................................................. xii

Chapter

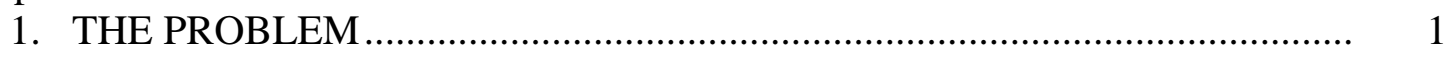

Background to the Problem ....................................................................

Job Preparedness ............................................................................ 1

Alumni Perception of Job Preparedness ........................................ 2

Employer Perception of Job Preparedness..................................... 2

Need for Evaluation of Job Preparedness ............................................... 3

Statement of the Problem......................................................................... 4

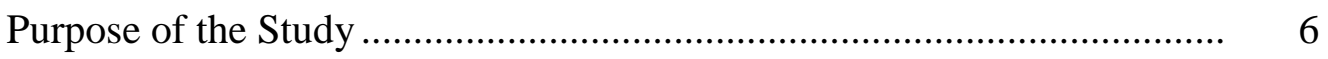

Assumptions.................................................................................... 7

General Research Questions ................................................................. $\quad 7$

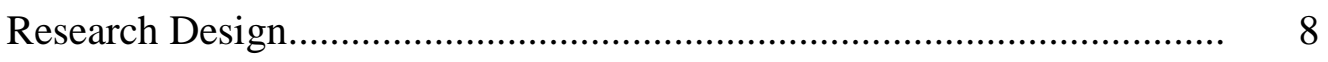

Conceptual Framework .......................................................................... 9

Significance of the Study ………….................................................... 10

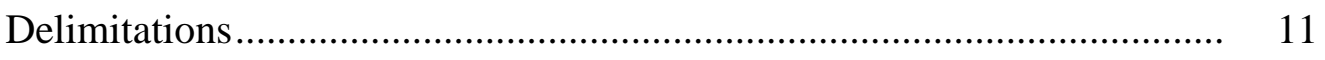

Definition and Operational Terms …………………........................... 12

Organization of This Document........................................................... 15

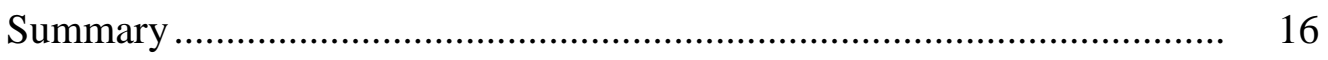

2. REVIEW OF THE LITERATURE ………………….............................. 17

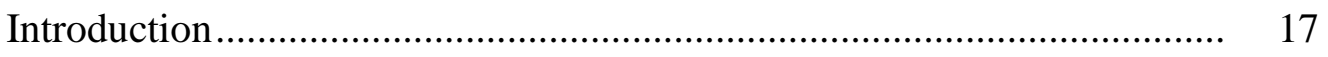

History of Theological Education ............................................................ 18

Historical Views of Theological Education......................................... 18

Themes Noted in History ……........................................................ 21 
The Role of College Education for Job Preparedness .............................. 22

Effectiveness of College Education .................................................... 23

Reasons for Ineffectiveness .......................................................... 24

Challenges of Job Readiness for Ministry ………………....................... $\quad 26$

Internship Programs and Job Readiness ................................................ 29

History of the Internship Model........................................................ 29

Benefits of Internships Programs ...................................................... 30

Internships in Theological Education ................................................. 31

Benefits of Internships in Theological Education.......................... 31

Length of Internship Program ................................................... 32

Alumni Evaluation of Job Preparedness ................................................. 32

Benefits of Alumni Evaluation .......................................................... 33

Frequency of Alumni Evaluation........................................................ 34

Challenges of Alumni Evaluation ....................................................... 34

Conceptual Framework ………………............................................. 35

The CDC's Framework for Program Evaluation .................................. 36

Application to This Research.......................................................... 38

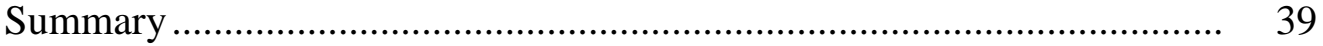

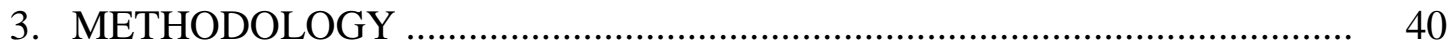

Research Design............................................................................ 40

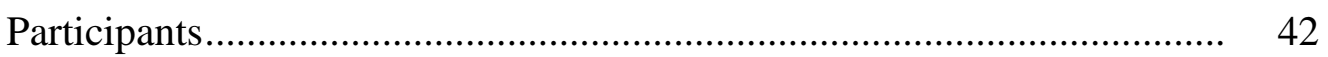

Sample Size ....................................................................... 42

Sampling Procedures ………………………………................ 42

Ethical Considerations ........................................................................ 43

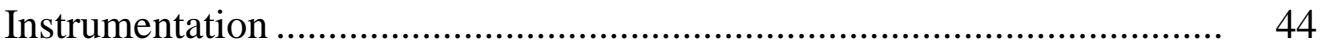

Content Validity and Table of Specifications ...................................... 45

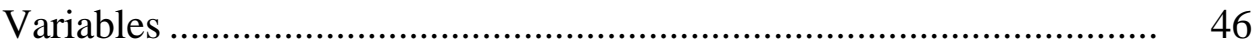

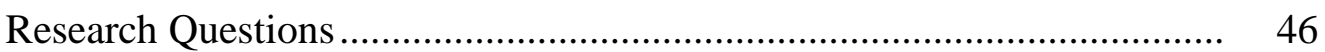

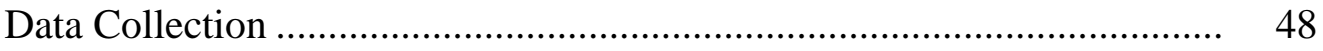

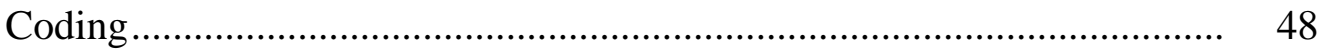

Statistical Analysis .................................................................... 49

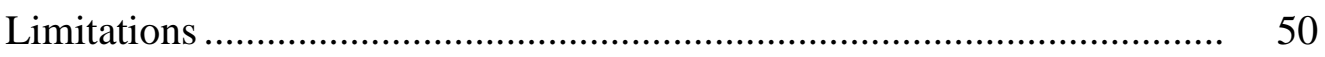

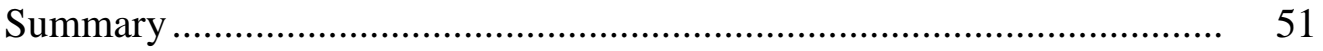

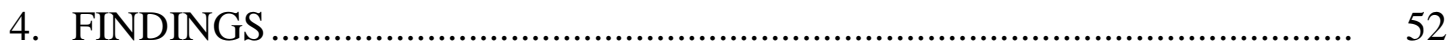

Table of Specifications .................................................................... 52

Data Preparation and Management ..................................................... 56

Description of Sample..................................................................... 57 
Rating and Ranking of Professional Courses........................................... 58

Correlation for Rating of Professional Courses ................................... 61

Regression Analysis for Rating of Professional Courses .................... 65

Chi-Square Analysis for Rating of Professional Courses .................... 67

Correlation for Ranking of Professional Courses ............................... 68

Regression Analysis for Ranking of Professional Courses................... $\quad 70$

Chi-Square Analysis for Ranking of Professional Courses .................. 71

Perception of Preparedness for Pastoral Competencies.............................. $\quad 72$

Qualitative Results ............................................................................ 75

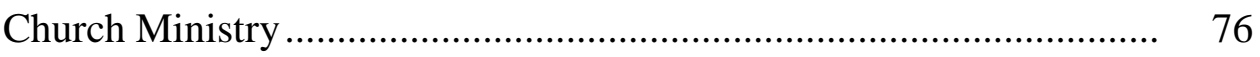

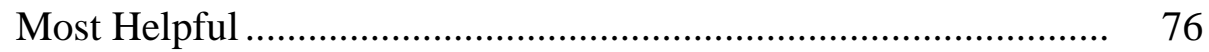

Least Helpful................................................................... 78

Suggestions for Improvement ..................................................... 78

Evangelistic Preaching and Public Evangelism ................................... 80

Most Helpful ................................................................... 80

Least Helpful............................................................... 82

Suggestions for Improvement ................................................. 83

The Ministerial Externship Program ................................................... 84

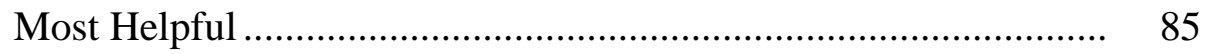

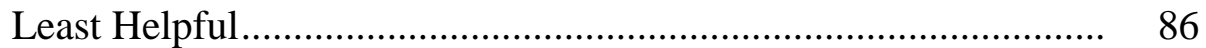

Suggestions for Improvement .................................................. 87

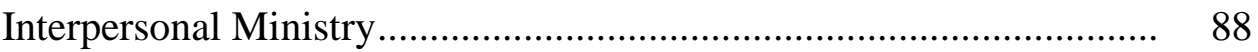

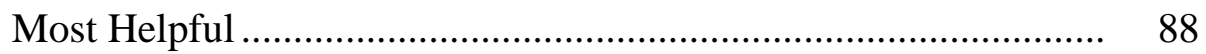

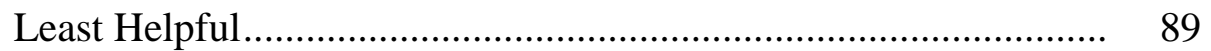

Suggestions for Improvement .................................................. 90

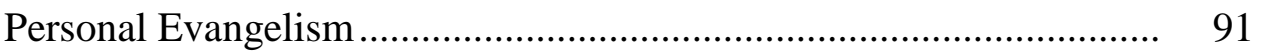

Most Helpful ........................................................................ 91

Least Helpful................................................................. 92

Suggestions for Improvement .................................................... 93

Reasons for Rating the Professional Courses ...................................... 94

Externship Program …….................................................. 94

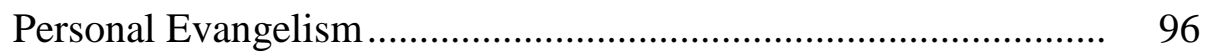

Evangelistic Preaching and Public Evangelism ............................. 96

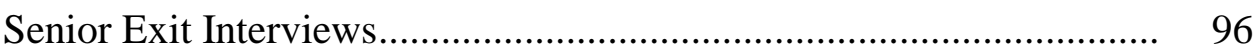

Most Helpful ..................................................................... 97

Suggestions for Improvement .................................................... 99

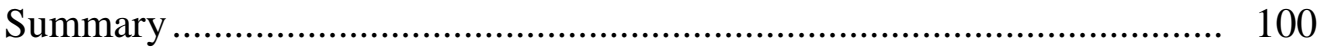

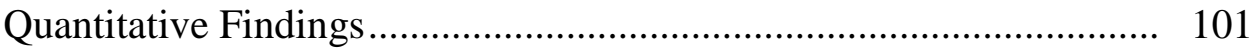

Qualitative Findings.................................................................... 102 
5. CONCLUSIONS, DISCUSSION, AND RECOMMENDATIONS

Methodology ...................................................................................... 105

Characteristics of Sample ................................................................... 105

Discussion of Findings ...................................................................... 106

Limitations ................................................................................. 113

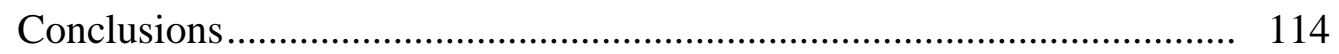

Recommendations .......................................................................... 115

Recommendations for the School of Religion Faculty ..................... 115

Recommendations for Curriculum Development ............................ 118

Recommendations for Adventist Conferences and Unions ............... 120

Recommendations for Further Research........................................ 121

Final Thoughts ........................................................................... 122

Appendix

A. IRB APPROVAL AND LETTERS .................................................... 123

B. CONSENT FORM AND SURVEY INSTRUMENT ................................ 126

C. TABLE OF SPECIFICATIONS .......................................................... 135

D. CODED SURVEY INSTRUMENT ................................................. 141

E. ADDITIONAL TABLES NOT PLACED IN PAPER ................................ 148

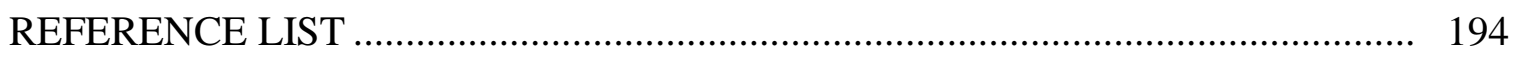

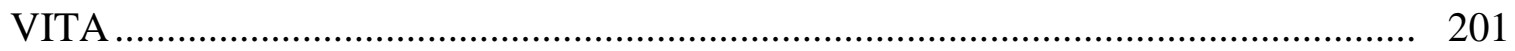




\section{LIST OF TABLES}

1. Table of Specifications - Church Ministry ………………………………...... 53

2. Table of Specifications-Evangelistic Preaching and Public Evangelism....... 54

3. Table of Specifications - Interpersonal Ministry............................................... 54

4. Table of Specifications_-Personal Evangelism.............................................. 55

5. Table of Specifications_-Percent of Topic Sufficiency …………………....... 56

6. Gender, Ethnicity, and Marital Status ......................................................... 58

7. Graduation Year, Seminary Attendance, Time of Seminary Attendance ......... 59

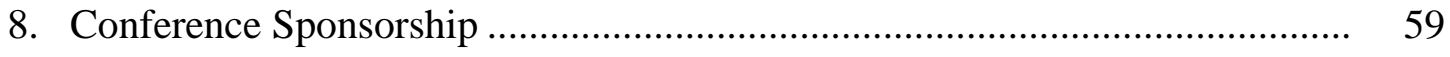

9. Elementary and High School Education ......................................................... 60

10. Currently Pastoring, Degree at SAU Again, Perception of SAU Undergraduate Training ...................................................................... 60

11. Rating of Professional Courses ........................................................................ $\quad 62$

12. Ranking of Professional Courses .................................................................... 63

13. Point Bi-Serial Correlation for Rating of Professional Courses ....................... 64

14. Summary of Linear Regression Analysis for Variables Predicting Rating of Personal Evangelism.......................................................................... 66

15. Summary of Linear Regression Analysis for Variables Predicting Rating of Evangelistic Preaching and Public Evangelism...................................... 67

16. Year of Graduation and Rating of Externship Program................................... 69

17. Graduating 2000-2005 and Rating of Externship Program............................. 70 
18. Graduating 2011-2014 and Rating of Externship Program.............................. 71

19. Graduating 2006-2010 and Rating of Externship Program............................ 72

20. Point Bi-Serial Correlation for Ranking of Professional Courses .................... 73

21. Summary of Regression Analysis for Variables Predicting Ranking of Personal Evangelism ......................................................................... 75

22. Church Ministry: Most Helpful .................................................................. 77

23. Church Ministry: Least Helpful ..................................................................... 79

24. Church Ministry: Suggestions.................................................................... 80

25. Evangelistic Preaching and Public Evangelism: Most Helpful ......................... 81

26. Evangelistic Preaching and Public Evangelism: Least Helpful ........................ 83

27. Evangelistic Preaching and Public Evangelism: Suggestions .......................... 84

28. Ministerial Externship Program: Most Helpful ............................................. 85

29. Ministerial Externship Program: Least Helpful ................................................ 86

30. Ministerial Externship Program: Suggestions ................................................ 88

31. Interpersonal Ministry: Most Helpful ....................................................... $\quad 89$

32. Interpersonal Ministry: Least Helpful........................................................ 90

33. Interpersonal Ministry: Suggestions …………………................................ 91

34. Personal Evangelism: Most Helpful ............................................................ 92

35. Personal Evangelism: Least Helpful ............................................................ 93

36. Personal Evangelism: Suggestions ……………………………………..... 94

37. Reasons for Rating the Professional Courses …………………………......... 95

38. Senior Exit Interviews: Most Helpful .......................................................... 98

39. Senior Exit Interviews: Suggestions to Improve Program............................... 100 


\section{LIST OF FIGURES}

1. CDC Framework for Program Evaluation ......................................... 37

2. Graphic Presentation of Research Design............................................. 41 


\section{LIST OF ABBREVIATIONS}

$\begin{array}{ll}\text { CDC } & \text { Center for Disease Control and Prevention } \\ \text { NAD } & \text { North American Division } \\ \text { QL } & \text { Qualitative } \\ \text { QN } & \text { Quantitative } \\ \text { SPSS } & \text { Statistical Package for Social Sciences } \\ \text { SOR } & \text { School of Religion }\end{array}$

Southern Southern Adventist University 


\section{ACKNOWLEDGEMENTS}

I want to express appreciation to those who have encouraged me on this marathon journey. These include my cohorts through the years, Brenda Peiffer-Boyd, and Jhenifa Parker. Special thanks also to my dissertation committee Drs. Erich Baumgartner, Stan Patterson and Isadore Newman whose patience, wisdom and knowledge have moved this project along. I also want to thank my family for their love, encouragement and support through this process: my wife, Lilly, our sons Daniel and David, and my brother Ric Tryon. Your belief in me means the world. 


\section{CHAPTER 1}

\section{THE PROBLEM}

\section{Background to the Problem}

"The goal of theological education is to produce effective ministers" (Wong, 2009, p. 250). Theological seminaries are charged to "train, educate and prepare ministers for service in churches" (Ellington, 2004, p. 43). Others join the chorus that the purpose of undergraduate theological education and especially theological seminaries exist for the primary purpose of educating students for church-related ministry (McKinney, 2003).

While few would disagree with the purported general purpose of theological education at institutions of higher education, there are questions that beg to be answered. How does an institution know that it is accomplishing the goal of preparing students for ministry? How is that goal defined? Who establishes the parameters that determine if the goal is successfully reached? When can that be determined? How is ministry defined in today's ever-changing society? Are theological schools adequately preparing students for the skills necessary for successful pastoring?

\section{Job Preparedness}

The issue of job preparedness does not apply solely to theological academia. This theme is prevalent in the literature today. It is a pressing question asked by parents who may be paying the tuition costs, by students who are trusting that their choice of college 
or university for a degree is going to provide the education necessary for employment, by employers who will be looking to hire graduating seniors, and by the federal and state funding agencies who demand accountability from the institutions they support financially (Burnsed, 2010).

\section{Alumni Perception of Job Preparedness}

The literature sends back a conflicting analysis of how institutions of higher education are doing at job preparedness as viewed from the perspective of both students and prospective employers. Martin, Milne-Home, Barrett, Spalding, and Jones (2000) found that students felt very satisfied with their college education and how well they were prepared. Another study found that more than $85 \%$ of recent graduates felt prepared by colleges in the skills and knowledge needed for their vocations (Corrigan, 2011). This confidence in job readiness may be inflated, however, as Bentley University (2014) noted that college graduates often overestimate their preparedness for jobs, believing themselves more ready for the workforce than those who hire them. Other studies find students to be less positive about how well their college education prepared them for the workforce. Many graduates give a low score to their universities for job preparedness (Bentley University, 2014). Furthermore, Stone, Van Horn, and Zukin (2012) found that as many as one-half of graduating students felt they were less prepared for their jobs than the previous generation.

\section{Employer Perception of Job Preparedness}

While the research on perception of job preparedness by alumni is mixed, studies on employer perception of job preparedness take a less optimistic view. The research indicates that employers are not satisfied with the level of job preparedness of the college 
graduates hired. Many feel that the graduates are only partially prepared, or in some cases, not prepared at all. The U.S. Department of Education (2006) cites complaints from employers that graduates are not prepared and lack skills for career development. Likewise, a 2013 study found that employers feel that colleges are not preparing graduates for the workforce and that business leaders give undergraduate education a poor score on preparing graduates for the workforce (Gallop, 2014). Another study found that some employers find that their new hires have proficiency in "hard" skills that deal directly with their area of discipline, but are lacking the "soft" skills such as teamwork and people skills (Bentley University, 2014). Some employers feel that undergraduate education has prepared new hires for basic entry level jobs, but express concern that it does not adequately prepare students for higher-level positions (Henscheid, 2008).

\section{Need for Evaluation of Job Preparedness}

One possible reason for conflicting information on how well colleges and universities do at preparing their graduates for the workforce may be in the difficulty of defining what "prepared" even means. Bentley University (2014) found little clarity on the subject and noted that explanations of "job readiness" varied between students, alumni and employers. How can an organization measure what it cannot define?

Despite the mixed evaluation of job preparedness by students, alumni and potential employers, it is agreed that a college degree is still considered important for obtaining a job (Bentley University, 2014; Gallop, 2014). In Current Issues in Economic and Finance, Abel and Deitz (2014) concluded that despite rising costs of education and declining pay for college graduates, a college degree is still a good investment for those 
with either a bachelor's or associate's degree compared to those with only a high school diploma.

While a college degree is still an important factor in job preparedness for graduating seniors, there is a need for more data on program evaluation to help determine the strengths and weaknesses of curricula and its effectiveness in preparing students for the workforce. Such information may be helpful to institutions of higher education, students who attend, and potential employers who will be looking to hire students upon graduation.

\section{Statement of the Problem}

As noted in the preceding section, there is a general need for evaluation of the effectiveness of academic programs in preparing graduates for the workforce. There is also a need to examine job preparedness in the education of students preparing to become pastors. Are theology students receiving the necessary education at either the undergraduate or seminary level that will prepare them for pastoral ministry in a local church? Are the courses they take giving them the professional skills crucial for leading today's churches and society? Manfred Kohl (2006), who has extensively researched theological education by seminaries in the Philippines, writes that there is a need for continued research to help provide data to answer these and other questions.

This lack of information on curricula effectiveness for ministry preparedness limits informed decision-making on the content included in professional ministerial courses. Thus, content may continue to be taught despite being no longer effective or relevant to the changing needs of ministry. In addition, evaluation of programs and curricula is an essential element of sound governance of educational policies. 
Over a decade ago, the School of Religion (SOR) at Southern Adventist University (Southern) implemented several changes to the practical portion of the educational process for its theology students to improve the quality of the product and better prepare graduating theology majors for pastoral ministry. Those changes included a stronger focus on preaching (adding an additional semester of coursework), extending the externship program to two years in a local congregation, and requiring every graduating senior theology major to personally conduct an evangelistic series before graduation. The reason for these changes was to give graduating theology majors more practical education that included both theory (classroom material) and praxis (hands-on experience) in areas of ministry they would need upon entering ministry.

On the surface, the program adjustments for theology majors seem to be effective. Alumni from time to time share with SOR faculty how helpful their undergraduate education at Southern was for pastoral ministry. But there has been no data collected to evaluate the effectiveness of the education as graduates move from the classroom to the local church. While anecdotal evidence seems to indicate that the practical courses are indeed preparing theology majors for pastoral ministry, is this accurate? What aspects of the curricula have been useful in the field? What has been most helpful? What could be strengthened? What needs to be added to the content of the courses? What do former students wish they had been exposed to before leaving Southern? Is the curriculum relevant for the changing role of pastoral ministry in an ever-changing society? What adjustments need to be made?

Additionally, there is a need to know whether Southern's program is effectively preparing theology majors who do not attend seminary after their college degree. While 
the North American Division (NAD) of the General Conference of Seventh-day Adventists (2015-2016, L 05 06) educational policy for entrance into ordained ministry requires seminary education as a part of ministerial training, this policy is not consistently carried out by local conferences. Some Southern graduates never advance beyond a college degree, but immediately transition into a church setting to work as a pastor. To date, the changes in curricula at Southern have not been evaluated to determine if the current program is effectively preparing graduating theology majors for ministry in local churches. The question to be asked, then, is how effective are the professional courses in preparing students for full-time ministry?

Finally, there is the problem of an aging Adventist pastorate. At a recent conference for theological educators at Andrews University, data was presented that showed nearly half of the current Adventist pastors in the NAD will be eligible for retirement in the next ten years (NAD Ministerial Department, 2014). It is important that Southern's theological education program, in conjunction with Andrews University Theological Seminary, enable the local conferences to fill those vacancies with adequately prepared students.

\section{Purpose of the Study}

The purpose of this research study was to measure the perceived effectiveness of five professional courses (Church Ministry I \& II, Interpersonal Ministry, Personal Evangelism I \& II, Evangelistic Preaching and Public Evangelism, and the Ministerial Externship Program) taught in the undergraduate theological educational program at Southern for ministerial job preparedness. Objectives for the study included: 
1. Create a survey instrument with good estimates of reliability and validity to assess the perceived effectiveness of five professional ministerial courses taken by theology majors at Southern for ministerial job preparedness.

2. Investigate the relationships between gender, ethnicity, year of graduation, seminary attendance, and five professional ministerial courses taken by theology majors at Southern when it comes to perceived effectiveness for ministerial job preparedness.

3. Determine if senior exit interviews are predictors of perceived effectiveness for ministerial job preparedness.

\section{Assumptions}

This research assumed that the effectiveness of an undergraduate theological education for preparing students for ministry can be evaluated. It was also assumed that the alumni survey data regarding the effectiveness of the five professional courses will be reflective of how prepared they were for pastoral ministry. Due to the use of a convenience nonprobability sampling method, another assumption is that the sample of theology graduates between 2000 and 2014 will represent the population to which the study will infer (Newman \& McNeil, 1998). Additionally, it is assumed that the respondents will answer the questions truthfully and consistently.

\section{General Research Questions}

The following research questions were used to form the basis of this study to measure the perceived effectiveness of five professional ministerial courses taken by theology majors at Southern for ministerial job preparedness. 
1. Are gender, ethnicity, year of graduation, and seminary attendance individually predictive for how they relate to the five professional ministerial courses studied?

2. Out of the five professional ministerial courses studied, will there be significantly different ratings in terms of the perceived effectiveness by the graduate in the following variables when controlled for the other variables in the prediction equation: gender, ethnicity, year of graduation, and seminary attendance?

3. Out of the five professional ministerial courses studied, will there be significantly different rankings in terms of the perceived effectiveness by the graduate in the following variables when controlled for the other variables in the prediction equation: gender, ethnicity, year of graduation, and seminary attendance?

4. For each of the five professional ministerial courses studied, which concepts will be most/least helpful for ministerial job preparedness?

5. For each of the five professional ministerial courses studied, which topics will graduates suggest adding/eliminating, and why?

6. Does the senior exit interview predict future perceived effectiveness of professional ministerial courses for ministerial job preparedness?

\section{Research Design}

This research utilized a mixed methods study design to evaluate the perceived effectiveness of five professional ministerial courses by graduates from the theology program at Southern. Tashakkori and Newman (2010) assert that this method enables examination of the research problem from multiple perspectives and types of data (quantitative and qualitative). A non-probability sample (Creswell, 2012; Doherty, 1994) 
of Southern theology graduates from May 2000 to December 2014 was conducted. Several studies have shown the value of alumni surveys for curriculum evaluation (Landrum, Hettich, \& Wilner, 2010; Vail, 2008; Wong, 2009). A mixed questionnaire was utilized, consisting of Likert-scale (Creswell, 2012) and open-ended questions regarding alumni perceptions of five professional courses taken at Southern. Descriptive and inferential statistical analyses (Howell, 2010) were utilized to examine the data collected. In addition, exit interviews of graduating seniors from December 2008 to December 2014 were reviewed for themes related to their perception of the five professional courses (Gubrium \& Holstein, 2001). This data was compared with the alumni questionnaire results to determine if exit interviews are good predictors for ministerial job preparedness. See Chapter 3 for more information about the research design.

\section{Conceptual Framework}

The conceptual framework underlying this research study is adapted from the Centers for Disease Control and Prevention's (CDC) six-step Program Evaluation Framework (CDC, 1999). This framework integrates evaluation theory, social science theory, and program theory, and provides a good example of an approach to evaluation that Donaldson has called program theory-driven evaluation science (Donaldson \& Lipsey, 2006).

The Program Evaluation Framework summarizes and organizes effective program evaluation into six steps. These steps include:

1. Engage stakeholders.

2. Describe the program. 
3. Focus the evaluation design.

4. Gather credible evidence.

5. Justify conclusions.

6. Use and share evaluation findings.

Although designed for use in evaluating public health programs (including training and education services), this model provides a systematic way to approach and answer the research questions in this study.

\section{Significance of the Study}

Findings from this study will contribute to the literature on the effectiveness of theological education. Although dissertations have been written on the effectiveness of theological seminaries in pastoral preparedness (Hebert, 2010; Shell, 1984), there is little on the outcomes of undergraduate (pre-seminary) curricula. One notable exception is Fisher's work in the evaluation of theology students who participated in internship programs prior to going to seminary (Fisher, 2010). This is significant because some theology graduates complete an internship prior to attending seminary, and others enter pastoral ministry without ever going to seminary.

It is anticipated that knowledge gained from this research will assist the faculty of the SOR at Southern in measuring the effectiveness of some of the professional courses currently being taught, and will provide data with which to make informed decisions about curricula changes where necessary. It is also anticipated that the findings of this study may be useful to theology programs at other Adventist colleges and universities in North America, since they share the same goal of preparing students for employment by conferences within the United States and Canada. 
Furthermore, the research may have implications in the development of continuing education materials for those already in pastoral ministry. The need for continuing education after graduation is widely noted in the literature (Barna, 1993; Koepke, 2011; Lewis, 2000; Mead, 2005; Patterson, 1980). The findings may also help employers and others providing support to pastors with topics for continuing education, ministerial publications, training seminars, and pastors' meetings.

\section{Delimitations}

This research was conducted within the following parameters:

1. The focus of this study was delimited to the research questions and variables outlined in this proposal, including gender, ethnicity, year of graduation, seminary attendance, and five selected professional ministerial courses taught at Southern.

2. The sample of this study was students who graduated with a degree in theology from Southern between May 2000 and December 2014. These years were chosen because of the changes that were made in the curricula by the SOR at Southern in 2000.

3. The only courses evaluated in this study were the professional courses component of the program, and not courses in homiletics, theology, or biblical languages. These include (a) Church Ministries (RELP450, RELP452), (b) Personal Evangelism (RELP361, RELP362), (c) Interpersonal Ministry (RELP270), (d) Evangelistic Preaching and Public Evangelism (RELP405, RELP466), and (e) the Ministerial Externship Program.

4. The measure of perceived effectiveness for ministerial job preparedness was studied, not actual observable behavior. 
5. There was no randomization of survey participants. Rather, every graduate from the years studied had the opportunity to self-select if they wished to participate in the survey.

6. The engaged stakeholders in this study were limited to the current professors who teach the five professional courses and completed a Table of Specifications for the content taught in their courses, and to alumni who have graduated from Southern with a theology degree.

\section{Definition and Operational Terms}

The following definitions clarify key terms used in this study:

Theological Education: This term is used interchangeably with pastoral education, pastoral training, and practical theology. Pastoral education programs seek to equip future pastors with both theological knowledge and with the professional skills (preaching, church administration, counseling, etc.) to minister effectively. This research focuses on the professional skills of theological education.

Adventist: An abbreviation for Seventh-day Adventist, a denomination whose headquarters is in Washington, DC. This Protestant denomination has a vibrant $\mathrm{K}-12$ educational system and numerous colleges and universities offering degrees in a variety of disciplines, including theology and ministry.

Southern Adventist University: "Southern Adventist University is a co-education institution established by the Seventh-day Adventist Church, offering doctoral, master, baccalaureate, and associate degrees, and one-year certificates" (http://www1.southern.edu/about/history-and-mission/). It is located in Collegedale, Tennessee. The SOR at Southern is a part of a larger educational system for the 
education of pastors that includes the Master of Divinity degree from Andrews University Theological Seminary in Berrien Springs, Michigan.

Interpersonal Ministry: The course RELP270 Interpersonal Ministry is designed for the "development of listening skills and interpersonal communication in pastoral visitation" (Southern, 2013, p. 390). It is usually taken during the freshman or sophomore year.

Personal Evangelism: This two-semester course is taken in the junior year of the theology major. RELP361 Personal Evangelism teaches the "principles and practices of one-on-one evangelism" (Southern, 2013, p. 390). Skills covered in the first semester include giving effective Bible studies, friendship evangelism, youth ministry, and involvement with local church outreach programs. The second course, RELP362 Personal Evangelism, builds on the first, adding urban evangelism, small group outreach, and answering biblical objections. Laboratory work for both semesters is required in a local church.

Evangelistic Preaching and Public Evangelism: These two courses focus on the preparation and presentation of public evangelistic meetings. In RELP405 Evangelistic Preaching, students first learn how to prepare and deliver distinctively Adventist messages with an "emphasis on soul-winning decisions and use of multi-media" (Southern, 2013, p. 391). This classroom education is followed by RELP466 Public Evangelism, a field experience in a local church where the students learn "how to plan and hold an evangelistic series, as well as visit with evangelistic interests." This field experience is held in connection with the Field School of Evangelism at Southern. 
Students take the Evangelistic Preaching course in the second semester of their junior year, followed by the Public Evangelism course in the summer.

Church Ministries: This is a two-semester course for senior theology majors. RELP450 Church Ministries is taught in the first semester and provides an introduction to church ministry and a "biblical theology of church ministry, clergy, and laity." It also includes concepts of "church administration and the practice of some specific ministries in the local church setting" (Southern, 2013, p. 391). The second semester course, RELP452 Church Ministries, focuses on the "personal and professional life of the pastor" and covers topics such as spiritual leadership, life management, worship ministry, priestly functions (baptisms, weddings, and funerals), denominational policy, church growth, and the empowerment of the Holy Spirit for ministry. Laboratory work for both semesters is required in a local church.

Ministerial Externship Program: While not an academic course for theology majors, the Ministerial Externship Program is a requirement for completion of a theology degree and must be completed before the SOR will recommend a student for church employment. It is designed to "enhance professional development by acquainting the student with the multi-faceted responsibilities of ministry" (Southern, 2013, p. 251). It provides a four-semester internship under the experienced mentorship of local pastors and church leaders for membership care, evangelism, church leadership, worship, and preaching.

The Ministerial Externship Program is not the same as the internship program cited in the NAD working policy (NAD, 2015-2016). The purpose of the internship 
program in the NAD policy is for local hiring conferences to provide new pastors with field experience as they enter pastoral ministry.

Perceived Effectiveness: In the absence of objective measures for the effectiveness of the educational courses in preparing graduates for ministry, this research is relying on the perceived helpfulness by the alumni theology students as they reflect on the five professional courses taken at Southern. The five professional courses will be rated for helpfulness in pastoral preparation and also ranked to determine the most effective or helpful courses in preparing them for ministry (see items 14-25 in Appendix A).

Program Evaluation Framework is the conceptual framework used in this study. This six-step model was developed by the CDC for use in evaluating public health programs (including training and education services). This is described in detail in Chapter 2.

\section{Organization of This Document}

Chapter 1 presents the background to the problem, statement of the problem, purpose of the study, research questions, research design, theoretical framework, significance of the study, delimitations, and definitions of terms. Chapter 2 contains a review of the literature and research related to the problem under investigation. Additionally, Chapter 2 explores the CDC's Framework for Program Evaluation and its application to curriculum evaluation and this research study. Chapter 3 presents the methodology and procedures that was used to gather and analyze data for the study. In Chapter 4, an overview of the quantitative and qualitative findings is provided. Chapter 5 discusses the study findings and presents its conclusions and recommendations. 


\section{Summary}

Job preparedness is becoming a more important topic as the cost of higher education increases. While a college degree is still a key factor in job preparedness for graduating seniors, there is a general need for evaluation of the effectiveness of academic programs in preparing graduates for the workforce. However, there is little research in the literature on the outcomes of undergraduate (pre-seminary) curricula. The purpose of this research study was to evaluate the perceived effectiveness of five professional ministerial courses taken by theology majors at Southern for ministerial job preparedness. The research was guided by the CDC's Framework for Program Evaluation. The next chapter provides a more extensive review of the literature for the issues introduced in Chapter 1. 


\section{CHAPTER 2}

\section{REVIEW OF THE LITERATURE}

\section{Introduction}

Questions and concerns about the education of pastors for ministry have existed for decades. In 1926, Frederick Agar, past secretary of the Northern Baptist Convention and prolific author on church life, wrote in his book, The Local Church: Its Present and Future, the following assessment of theological education for the training of pastors: "For several generations, there has been a profound conviction that the theological seminaries are not producing men adequately trained to do the real work of ministry" (Agar, 1926, p. 39). Thirty years later a similar assessment of theological education is given in an article by Professor Kenneth Rogers when he stated that the "persistent demand is for a more effective pastoral ministry" (Rogers, 1956, p. 161). Toward the end of the $20^{\text {th }}$ century, the same concerns can still be found in research and publications (Barna, 1993; LaRue, 1995; McKinney, 2003).

This chapter gives a brief overview of the history of theological education, from biblical days until the present time. Secondly, a review of the literature on the effectiveness of college education for job preparedness in general is discussed, followed by research that specifically address ministry preparedness. Internship programs are also examined in light of job preparedness. Next, alumni evaluation of education is considered as an important resource for the evaluation of an educational program's 
effectiveness for work preparedness. Finally, a more in-depth view of experiential learning theory is provided, along with its application to this research project.

\section{History of Theological Education}

In 1971, Rowdon observed that information on the history of theological education was a "neglected field" (Rowdon, 1971, p 75). That cannot be said today. Though some early works existed (Niebuhr, Williams, \& Gustafson, 1957) when Rowdon made his observation, much has been written since about the history of theological education. David Kelsey's Between Athens and Berlin (1993) is perhaps one of the most recognizable sources, but others such as Shell (1984), Lewis (2000), Ellington (2004), Kohl (2006), Hollinsworth (2008), and Vail (2008) have added much to our understanding of how ministers have been educated from biblical times until today. Cannell (2006) and Hebert (2010) provide more detailed information and perspective tracing the history of theological education and the training of pastors.

\section{Historical Views of Theological Education}

While it is not the purpose of this literature review to fully examine the history of theological education, a brief overview can help give context to where we are today in the education of clergy. Hebert's historical views of theological education (which are similar to Cannell's) give us an overview from biblical times to today, sharing some interesting shifts in emphasis (Hebert, 2010). Biblical examples of theological education, which encompass both the Old and New Testaments, are best summarized by the term discipleship. Looking at the preparation of the Levites, novice priests, young prophets, Jesus' training of the 12 disciples, and the Apostle Paul's training of Timothy and others, Hebert sees theological education as "incarnational" in nature. The goal of education in 
biblical times was to transform learners "into the image and likeness of Christ" (p. 2829).

This biblical view of theological education continued for a millennium, albeit heavily influenced by the philosophies of Plato and Christianized Hellenism. The emphasis of theological education was upon the preparation of the individual for ministry. There were four "keys" for this preparation: (a) personal preparation for ministry (personal life, spirituality, moral formation); (b) an acknowledgement and call to the role of ministry by the church; (c) demonstration by the candidate of being a theologian; and finally, (d) an understanding and knowledge of the practical skills of ministry (Hebert, 2010). This preparation was completed in the church and in the context of an older, more experienced mentor.

Hebert (2010) contends that a second historical view of theological education can be seen emerging around the time of the Great Schism of 1054. During this period, there was a move away from the biblical and early church model of theological education. Rather than preparing a candidate's heart for ministry, the focus shifted to filling the mind. Universities were created with full-time, professional teachers (versus teachers with pastoral experience) and curricula of knowledge to pass on to students. The teaching style consisted of lecture and debate. There was a separation of theology from philosophy, resulting in philosophy and revelation considered to be equal.

The Protestant movement of the $16^{\text {th }}$ and $17^{\text {th }}$ centuries brought further changes to theological education (Hebert, 2010). Reformers like Martin Luther believed that history, grammar, and ancient languages were all that were needed by clergy for spreading the gospel. There was a reduction in the curricula of the liberal arts courses and a strong 
focus on courses that had mostly theological content. However, it is important to note that the focus of this education was on a cognitive level rather than the practical training noted in the earlier biblical era.

The next historical view mentioned by Hebert (2010) began in the early 1800s, during which theological education added the emphasis on the scientific method. This focus on research and not the Bible for ultimate truth led to critical inquiry and a methoddriven model for discovery. Reason became the ultimate authority.

Hebert (2010) has noted that theological education shifted back to the apprenticeship model for the training of pastors in the new world, due to the absence of universities in Colonial America. As the country grew and developed, however, schools were again established and moved toward a more academic model of seminaries.

Another historical view of theological education identified by Hebert (2010) in the latter part of the $19^{\text {th }}$ century was a hybrid approach used to integrate scientific research methods and the craft of ministry. Pastoring was considered a vocation or profession. As a result, education focused on professional skills for managing people and communities, rather than knowledge of the scriptures. Today's undergraduate and graduate schools for theological education are considered professional schools, combining academic education and professional skills.

Hebert views contemporary theological education as a hybrid of some of the previous historical views, combining professional education with scientific method. $\mathrm{He}$ concluded, "the minister today looks nothing like the pastor of the ancient church of the first millennium" (Hebert, 2010, p. 45). 


\section{Themes Noted in History}

There are two themes that appear in the literature on the history of theological education. The first is that change has occurred often. As noted in Hebert's historical views of theological education, changes in society and in the church have resulted in the addition and adaptation of philosophies and educational approaches for the education of pastors for ministry. Many examples are cited in the literature, such as:

(a) apprenticeship with an experienced pastor (Hebert, 2010; Patterson, 1980); (b) founding of new schools and universities (Hebert, 2010; Patterson, 1980; Shell, 1984); (c) development of specific professional education programs like clinical pastoral education (Hollingsworth, 2008); (d) changes in faculty qualifications - a shift from teachers with pastoral experience to educated specialists (Ellington, 2004); (e) field education (Hollingsworth, 2008); and (f) supervised ministry (Hollingsworth, 2008).

A second theme is that much of the educational history shows a constant struggle to balance the academic/intellectual education and the practical/skill component that is just as necessary. This is noted in Hebert's (2010) historical views of theological education, as well as by many others (Cannell, 2006; Patterson, 1980; Vail, 2008). Patterson (1980) makes an interesting observation on what he sees as a progression of theological education in history. First, there was the need for formal education of the clergy. This was followed by the founding of schools in the $18^{\text {th }}$ and $19^{\text {th }}$ centuries for the education of clergy. Next, there was a shift in those schools to move toward the emphasis on scholarship. Finally, the shift towards scholarship led to a neglect of the practical/professional aspects of pastoral ministry. While Patterson sees this as one progression over time, it can also be a reoccurring cycle in theological education that has 
repeated several times in history. One prime example can be found in the history of clergy education in America (Hebert, 2010). In early American history, due to the lack of theological schools in America, theological education during that era reverted to the biblical model of discipleship or apprenticeship.

It seems that theological education is once again at a crossroads regarding a need to respond to changes in society and the tension between scholarship and practical education. Cannell (2006) has observed that some churches are looking for new models for the education of pastors other than through the seminary. This emphasizes the need to evaluate the effectiveness of current theological education.

\section{The Role of College Education for Job Preparedness}

While the focus of this research is on how well theology students are prepared for ministry, the topic of the workforce readiness of college graduates in every discipline is a relevant topic today. This is due, in part, to the rising costs of obtaining a college degree and questions about the current and future of the economy. Yet, despite these concerns, research indicates that a college degree is still a good investment and will, for many majors, produce a positive rate of return on investment (Abel \& Deitz, 2014).

Furthermore, a college degree is still considered an essential component of job preparedness. In a recent Gallop (2014) poll, Americans were asked about the importance of a college degree in today's work environment. An overwhelming 94\% believed that it is important to have a degree or certificate beyond a high school diploma. Not only did they believe post-high school education to be important now, but $84 \%$ of respondents thought that a college degree would be even more important for the workplace in the future. The study also found that $75 \%$ of Americans felt that a 
bachelor's degree could lead to a good job. In research done by Bentley University (2014), participants responded similarly. In addition to believing that a college degree was important today for a job, $74 \%$ of college students and $62 \%$ of the business decision leaders surveyed believed that a college education was a predictor of success in the workplace for the graduate.

\section{Effectiveness of College Education}

Although considered a worthwhile investment and important for job preparedness, current literature reveals mixed responses regarding the effectiveness of a college education for workforce readiness. An initial perusal of the literature seems to show a trend of satisfaction by alumni toward the degree they received from college. One research study found a large satisfaction in alumni with the level of job preparedness attained by their education (Martin et al., 2000). In another study by Stone et al. (2012), graduates believed that the education they received did a good job of preparing them to be successful in their jobs. Corrigan (2011) reported that well over 70\% of alumni indicated they were satisfied with the knowledge and skills they received and would attend the same institution if they had to do it all over again. Potential employers also rated satisfaction with how colleges prepared students for the workforce (Henscheid, 2008).

On the other hand, many research studies show an opposing view of the job readiness provided by a college degree. A study done by the American Council of Education found that while more than $85 \%$ of alumni felt their undergraduate degree had prepared them for their current job, a smaller percentage (62\%) felt that colleges in general were preparing students for today's workforce (Corrigan, 2011). A Gallop 
(2014) poll puts that number even lower. Their survey suggests that only $43 \%$ of Americans say today's graduates are well prepared for the workplace. In a large study by a worldwide management consulting firm, researchers found that $30 \%$ of college students felt that college did not prepare them for employment (McKinsey \& Company, 2013). That number is consistent with the findings of the American Council of Education (Corrigan, 2011), in which $38 \%$ of alumni surveyed felt colleges in general were not preparing students for the demands of today's workforce. Even after reporting that the education they received did prepare them to be successful in their jobs, Stone et al. (2012) found that one-half of the graduates in their study felt they were less prepared for the workforce than was the previous generation. The final grade for colleges and their ability to prepare their graduates for the workplace was average at best. Bentley University (2014) concluded that, across the board, business decision makers, recruiters, business leaders, and graduates gave the educational system a grade C or lower (49\%$61 \%$ ) on job preparedness.

\section{Reasons for Ineffectiveness}

There are many reasons for fair to poor reviews of undergraduate education for preparing students for the workforce. The research seems to indicate that one reason is due to the varied skillsets needed for different jobs. Business leaders surveyed by Gallop (2014) found that only $11 \%$ say they hired graduate students with the skill sets needed by their business. Another reason is that businesses are looking for more than academic education, or "hard" skills, in their employees. Bentley University (2014) defined hard skills as the tangible technical, professional, or prescribed skills needed for doing a job. Although these hard skills are the outcome-based focus of higher education, employers 
are finding that the "soft" skills are missing in those they hire out of college (Bentley University, 2014). These soft skills vary from study to study, but include proficiencies such as:

- Prioritizing, planning, and decision-making (Martin et al., 2000; McKinsey \& Company, 2013; The Chronicle of Higher Education and American Public Media's Marketplace [Chronicle], 2012)

- Organizational skills (Landrum et al., 2010; Martin et al., 2000; McKinsey \& Company, 2013)

- Leading a group to a common goal, and the ability to work with others (Martin et al., 2000; McKinsey \& Company, 2013)

- Adaptability (Bentley University, 2014; Chronicle, 2012)

- Good attitude (Bentley University, 2014)

- Respect (Bentley University, 2014)

- Maturity (Bentley University, 2014)

- Communication skills, both written and oral (Chronicle, 2012; Lotz, 1977; Martin et al., 2000)

- Conflict management (Landrum et al., 2010)

- $\quad$ Listening skills (Landrum et al., 2010)

- Problem solving (Chronicle, 2012; Martin et al., 2000)

- Integrity (Martin et al., 2000)

This list naturally leads to another reason why it is difficult for a college degree to prepare students to meet all the needs every employer may have: job readiness is too broad and hard to define (Martin et al., 2000). In a major study by Bentley University (2014), researchers found that the definition of job preparation means different things for college students than it does for those making employment decisions in the business world. 
While there is a general agreement on the importance of a college education in general, there is controversy over its effectiveness in job preparedness. Clearly, there is a need for evaluation of academic programs to meet the many challenges to effectively preparing students for the workplace.

\section{Challenges of Job Readiness for Ministry}

The challenges faced in effectively preparing students for the workplace are also noted in theological education. Questions of clergy job readiness have been around a while. Weeks (n.d.) cites a 1957 study by Niebuhr et al. who stated over 50 years ago that seminaries were woefully inadequate in preparing church leaders.

As noted in non-theological education, one of the biggest challenges of evaluating job readiness of graduates is lack of consensus on what qualifies as preparedness (Bentley University, 2014). The same holds true for theological education. The definition for what it means for a graduate to be ready for the ministry has not been established or, at best, is extremely vague. Wong (2009) also points out the difficulty of balancing between theory (knowing what to do) and practice (knowing how to do it).

Another challenge already noted is the difficulty in meeting the needs of all types of employers (Martin et al., 2000). Even within a single discipline such as theology, there are multiple roles and responsibilities for which graduates will need competency to meet expectations of potential employers. These competencies will vary greatly from employer to employer and from setting to setting (Hess, 2008; Wong, 2009). For example, the skill set needed by a hospital chaplain is different from that of a youth pastor on the staff of a large church or a pastor who serves three small churches alone. Gyuroka (2016) found that pastors struggled to define and explain the leadership dimensions of ministry. 
Even if an employer has a list of competencies in a ministry job description, that list would need to be dynamic in order to take into account the local context of ministry and the varying personalities of the pastors (Wong, 2009). Competencies that are needed or expected today continue to change over a lifetime for most professions, including those for pastors (Hess, 2008). What is needed today can easily change or be different in the future. This led Shell (1984) to conclude that education on both the college and seminary levels are not adequate for lifetime preparedness for the changing world in which we live.

Not only is it difficult to define and list competencies for ministry, another challenge to overcome in evaluating job readiness in theological education is that of assessing competencies in graduates. Lewis (2000) shares three areas of concern in the evaluation of theology students and the competencies they need for effective ministry: (a) developing and validating an instrument for evaluating competencies; (b) the expectation of professors who are teaching the courses; and (c) the training and proficiency of those who will be completing and interpreting the evaluations.

Another challenge of job readiness for ministry deals with the academic portion of education. There is tension between the academic, professional, and spiritual education needed in the preparation of pastors. The university or college must focus on the academic education while not neglecting the professional skills needed for successful ministry. These professional skills could include things such as counseling, management and administration, public speaking, preaching, and teaching (Saperstein, 2006). Others list skills such as time management (McDowell, 1977). Kemp (2010) correctly observes, "it has often proved difficult for academic institutions to maintain proper emphasis on 
ministry training and spiritual formation, while also achieving academic excellence" (p. $133)$.

Another aspect of the tension between academic, professional, and spiritual education is the needs and wants of the stakeholders - the denominations and their local entities who will be hiring students as pastors after graduation. In the education of theology students, Kohl (2006) is not certain that educational institutions appreciate what churches really need in pastors. He encourages dialogue between those providing the education and the stakeholders who have an interest in the effectiveness of the education. Others cite the need for seminaries and churches to better connect in order to determine the education needed for pastoral ministry today (Ellington, 2004). Even when an externship program is included in theological education, there is concern that the student's brief work experience with a local parish is not at all comparable to the reality of pastoring a church or district independently (Foster, Dahill, Golemon, \& Tolentino, 2006).

Another challenge to academic programing for theological education lies in the accrediting process for higher education. Ellington (2004) observes that denominations have lost control of the content that seminaries can teach their students due to the accreditation entities. While denominational leaders may desire specific knowledge or skills in their pastors, colleges and seminaries are obligated to meet the requirements demanded by the agencies that give them accreditation.

A final challenge that ties in especially with the current study is how much education should be given to theology students in their undergraduate experience. Lewis (2000) correctly notes that seminary education builds on the foundation provided by 
undergraduate theology degrees. One concern for both the seminary and undergraduate programs, however, is that some students enter fulltime ministry without ever going on for graduate education. A survey of over 1000 Protestant pastors by Lifeway Research (2010) found that although pastors put a high value on seminary education, nearly onethird did not have a graduate degree. Undergraduate educational programs need to prepare students with foundational knowledge and skills for entering pastoral ministry upon graduation, as well as prepare them for the academic rigors of seminary education.

With all the challenges noted in effectively preparing students for the workplace, it is easy to wonder if job readiness for theology students at any level is even achievable. Research done by Lewis (2000) led him to the conclusion that "objective standardization of assessment of readiness is not possible" (p. 155).

\section{Internship Programs and Job Readiness}

While the question of workforce preparedness and job readiness continues, one component of education seems to be considered helpful by both students, alumni, and potential employers: internship programs for students while they are in college.

\section{History of the Internship Model}

Education has its historical roots in an apprenticeship or internship model (Foster et al., 2006). Up until the industrial revolution of the 1800s, master craftsmen taught various skills and trades to apprentices who would often live in the teacher's home as part of the family and business. From this vantage point, apprentices would not only be able to observe how the skill or craft was done, but also be educated in the societal and lifestyles expectations of those who made a living by the specific trade they were learning (Tryon, 2001). As education moved away from an on-the-job apprenticeship, learning 
began to shift toward theory and academics. As a result, there was less emphasis and time for practice.

The literature shows a shift back toward the use of an apprenticeship for education in the form of internships. There are many terms for the internship program. In his dissertation on a college internship program for theological training, Fisher (2010) gives several of the popular terms used in education: leadership development, apprenticeship, on-the-job-training, field education, and mentoring relationship. The internship program for theology majors at Southern is called the Ministerial Externship Program.

\section{Benefits of Internship Programs}

Much is written in current literature about the importance of the internship program in academic education and its relationship to workforce readiness for graduates (Lewis, 2000; Stone et al., 2012). The internship program is a valuable component in all disciplines of education. Students, alumni, and employers agree on the need for both academic and practical education in preparing graduates for the workplace (Bentley University, 2014; Foster et. al, 2006, Hess, 2008; McKinsey \& Company, 2013).

There are many noted benefits for integrating an internship program in the academic process. The first is student perception of job preparedness. Research indicates that students with real work experience prior to graduation rated themselves as feeling better prepared for the workforce (McKinsey \& Company, 2013). Another benefit is that employers indicate that experience in an internship program is a key factor in their decision to hire students upon graduation (Chronicle, 2012; Stone et al., 2012). This aligns with a Gallop (2014) poll revealing that managers making employment 
decisions look for applicants who have received an education comprising both knowledge and practical skills. An academic program that includes an internship provides this important combination. An additional benefit of integrating an internship program in college education may be in compensation. There is some indication that students who had participated in an internship program earned salaries as much as $15 \%$ higher than those who had not participated in an internship program (Stone et al., 2012).

\section{Internships in Theological Education}

The literature on education for theology students also shows the importance of and the need for an internship as a component of the educational process (Childs, 2011; Hess, 2008; Kemp, 2010; Kohl, 2006). As with non-theological education, the history of pastoral education has its roots in an apprenticeship model in which a young pastor in training would live with an experienced pastor to learn the function of ministry (Patterson, 1980).

\section{Benefits of Internships in Theological Education}

There are benefits to the use of an internship in the education of clergy. Like that of other disciplines, the combination of academic education and practical application in the learning process contributes to a more balanced approach to education. While academics are important in the educational process, it needs to be tied with professional or vocational training of the students. Theory and practice need to be connected (Wong, 2009) and the internship program is one way of doing this.

Another benefit specific to the education of clergy is the area of calling to ministry. A study by Fisher (2010) surveyed theology graduates who completed an 
internship at a local Baptist Church prior to going to seminary for graduate work. One of the findings was that the internship program helped students to better understand and embrace their calling to ministry. While many of the students continued to seminary for additional education, others decided they were not called to professional ministry and moved toward other careers. It appears that the internship helps to solidify or modify a person's perception of their call to pastoral ministry.

There is also the benefit of mentorship by the local pastor who is involved and experienced with ministry (Meadville, 2011). The internship has the potential for placing a student in a professional and personal relationship with someone who is already doing the work for which they are training. From this mentoring relationship, a student is not only able to learn from a trained professional how real ministry is done, but can also learn denominational culture and traditions from those who are mentoring them.

\section{Length of Internship Program}

Although the length of an internship varies from institution to institution, some are seeing the benefit of longer internship programs. Lewis' (2000) research found that internships of nine months to two years increased the readiness for pastoral ministry over short internships. The Meadville Lombard Theological School (2011) has lengthened their field-based experience for theology students by having it begin in the first semester of the education program and continuing until graduation.

\section{Alumni Evaluation of Job Preparedness}

As stated previously, evaluation of curricula is important for colleges and universities to determine the effectiveness of their education programs for job preparedness. One important resource for the evaluation of an educational program's 
effectiveness for work preparedness is the alumni who have graduated from the university. The term "post-purchase evaluation" is used to describe this method of seeking data for academic institutions (Martin et al., 2000; Morgan \& Shim, 1990). The literature is filled with the significance of this source of information for educational institutions (Landrum et al., 2010; Vail, 2008; Wong, 2009).

\section{Benefits of Alumni Evaluation}

Alumni feedback benefits the university in many ways. First, alumni can provide valuable feedback for developing and evaluating curricula (Lewis, 2000; Martin et al., 2000; Morgan \& Shim, 1990; Trinkleim \& Wells, 1989). In fact, Trinkleim and Wells (1989) felt that alumni are in a "unique position" to give feedback to the universities from which they graduated (p. 24). While already being utilized in medical schools (Curran, Xu, Dewald, Johnson, \& Reynolds, 2012), seminaries are beginning to use alumni feedback for their course development. Childs (2011) did research using alumni feedback on a training program for church planters. Though the program had been taught for 15 years, there was little evaluation to show its effectiveness. His use of alumni evaluation helped the university see the program from the eyes of those who had taken it (Childs, 2011). In another dissertation, Christine (2010) quotes a study by Bhatia on alumni perception of the doctorate of ministry program at Dallas Theological Seminary. Alumni responses enabled the seminary to improve the program.

Another benefit of alumni evaluation of courses is that it can reveal strengths and weaknesses in a program (Higgins, 2008). This evaluation is useful for program development, as it allows the institution to capitalize on its strengths while also addressing its weaknesses. Although some institutions may find this a bit threatening, 
Kohl (2006) found that even though alumni recognize deficiencies in their educational program, they are still quite satisfied with the educational training they received. The ability to give feedback to their alma mater may also have some marketing implications as alumni point potential students to their university because of the positive feelings about their own educational experience (Morgan \& Shim, 1990).

\section{Frequency of Alumni Evaluation}

The literature also speaks to the frequency of alumni evaluation, with the consensus that alumni input is something that should be regularly solicited. Vail (2008) believes that alumni evaluation should not be a once-and-done process (Vail, 2008). Although medical schools solicit alumni evaluations every ten years, Curran (2012) felt that a decade was too long between evaluations because of the rapid changes in medicine. His suggestion was for alumni evaluation every five years. In the field of theology, Vail (2008) suggests that the alumni evaluation should be done even sooner-every three to five years, and that the data collected need to be compared to see if there are any perception changes in the alumni evaluations. More frequent evaluations may be useful for longitudinal evaluation of programs and curricula, and help curriculum developers adapt their courses and lectures to a quickly changing culture.

\section{Challenges of Alumni Evaluation}

Although considered helpful, alumni evaluation for curricula development is not without its challenges and limitations. Escobar (2008) lists several potential areas of concern: (a) the time constraints of faculty; (b) proper format of the survey; (c) not having current mailing addresses; (d) changing attitudes of education over time; and (e) 
budget and confidentiality issues. While it is recognized that alumni evaluation is retrospective in nature (Martin et al., 2000), it has still been found to be a valid evaluation tool (Marsh, 1987).

\section{Conceptual Framework}

Program evaluation and curriculum evaluation are not new concepts. Glatthorn, Boschee, Whitehead, and Boschee (2012) provide a history of curriculum evaluation dating back to the late 1800s in the United States and as far back as $2200 \mathrm{BC}$ in China. Clearly, with such a lengthy history, it comes as no surprise that a variety of curriculum evaluation theories and models have been developed over the years (Glatthorn et al., 2012).

Kirkpatrick (2006) developed the well-known Four-Level Training Evaluation Model to objectively analyze the effectiveness and impact of training programs. In the first level of evaluation, Level 1: Reaction, the reaction of the trainees to the instructor, topic, material, presentation, and venue are measured. Level 2: Learning, measures the knowledge gained by the trainees as a result of participating in the training. An evaluator measures how well trainees have applied the knowledge gained in Level 3: Behavior. Finally, Level 4: Results determines the outcomes that the stakeholders gained as a result of the training.

While many evaluators have advocated the importance of theory in evaluation, Donaldson and Lipsey (2006, p. 1) assert that "the nature and role of theory in evaluation is often a contentious matter" and note that some feel little or no need for theory while others believe that theory is a major aspect of effective evaluation practice. Donaldson and Lipsey suggest an alternative by combining evaluation theory, social science theory, 
and program theory in a distinctive approach they call program theory-driven evaluation science.

Program theory-driven evaluation science is "the systematic use of substantive knowledge about the phenomena under investigation and scientific methods to determine the merit, worth, and significance of evaluands such as social, educational, health, community, and organizational programs" (Donaldson \& Lipsey, 2006, p. 17). Donaldson and Lipsey cite the CDC's "Framework for Program Evaluation" as a good example of this approach.

The CDC's Framework for Program Evaluation

The CDC's Framework for Program Evaluation was developed in the 1990s to assess the effectiveness of public health programs (CDC, 1999). Not only does the model synthesize existing practices for evaluation, such as Kirkpatrick's model, it also provides a standard for further improvement of these activities. This practical framework for evaluation consists of six steps (see Figure 1). The first step, Engage Stakeholders, identifies and engages those involved in the program, those served or affected by the program, and the primary users of the evaluation. This step is important because "when stakeholders are not engaged, an evaluation might not address important elements of a program's objectives, operations, and outcomes" (CDC, 1999, p. 5).

Step 2 is Describe the Program. The purpose of this step is to scrutinize the various aspects of the program being evaluated. Program descriptions include the mission, objectives, goals, and strategies of the program. This description enables the stakeholders to understand the way the program was intended to function, and how it has been implemented. 


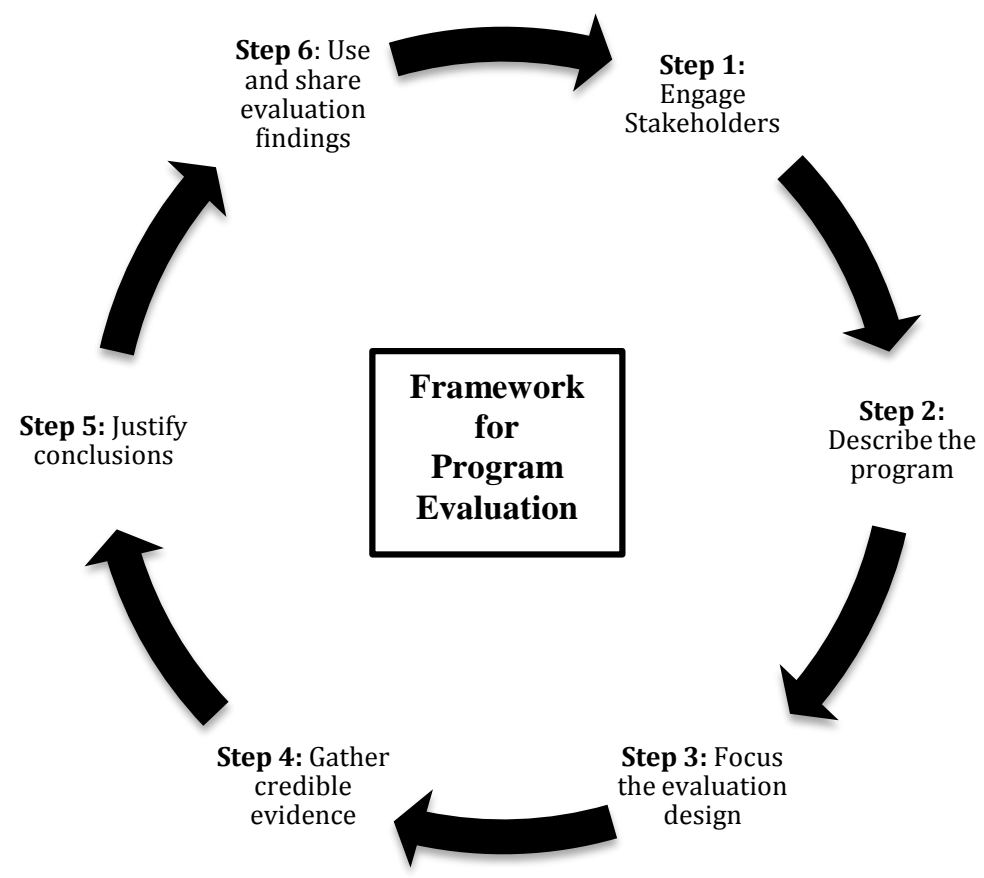

Figure 1. CDC Framework for Program Evaluation. Adapted from "Framework for Program Evaluation in Public Health" by U. S. Department of Health \& Human Services (1999). Morbidity and Mortality Weekly Report, 48(RR-11). Retrieved from http://www.cdc.gov/mmwr/PDF/RR/RR4811.pdf.

Step 3 is Focus the Evaluation Design. This step narrows the focus of the evaluation and identifies an efficient and effective design that will address the specific areas of concern to the stakeholders. Example activities include writing relevant evaluation questions to measure trainee reaction, knowledge, and application of new learning, as well as identifying practical methods for sampling, data collection, data analysis, and interpretation.

Step 4, Gather Credible Evidence, seeks to compile trustworthy and relevant data to paint an accurate picture of the program and answer the evaluation questions. A variety of methods can be used to collect data, including experimental, observational, qualitative, quantitative, and a mixed methods approach. This step is significant because 
valid data strengthens evaluation judgments and subsequent recommendations for the future of the program.

Step 5, Justify Conclusions, seeks to substantiate final recommendations based on the evidence. Example activities include comparison with standards, data analysis and synthesis, interpretation, judgment, and recommendations.

Step 6, Use and Share Evaluation Findings, is the final step of the model. In this step, evaluators seek to disseminate the findings from the evaluation to the stakeholders. Moreover, intentional follow-up is planned to facilitate decision-making and application.

A unique feature of this practical, non-prescriptive tool developed by the CDC is that it involves stakeholders and not just evaluation experts. In addition, it was created to be purposefully general. The framework "provides a guide for designing and conducting specific evaluation projects across many different program areas" (CDC, 1999, p. 34-35). The CDC also designed the framework to be used as a template that can be customized as appropriate for the program under evaluation.

\section{Application to This Research}

Beginning in 2000 the SOR at Southern made some major changes to the professional portion of its curricula for the education of theology majors. The faculty believed that the changes were necessary to better prepare students for the role of ministry — whether or not they planned to attend seminary. These changes included a requirement for theology students to preach an evangelistic series in a local church and an externship program in which students could relate with seasoned pastors in a mentoring relationship that would expose them to various aspects of ministry. However, there has been no formal evaluation of these changes. 
The characteristics of the CDC's Framework for Program Evaluation make it a good fit as a conceptual framework for this research study. Its clear and logical steps and the ability to customize the tools to meet the specific needs of Southern's SOR provided the flexibility necessary for adapting the framework to curricula evaluation. In addition, the involvement of many stakeholders (professors, alumni, and current students) offers a richer perspective than that of the researcher alone.

\section{Summary}

There have been many changes in the process of preparing pastors for ministry from biblical times to the present. It may be that theological education is once again at a crossroad. There is a need for the evaluation of current theological educational programs to meet the many challenges in effectively preparing students for ministry today.

Empirical data can be useful in making decisions for best curriculum design and changes. The literature reveals that college education and internship programs are a critical part of job preparedness, and that alumni feedback is vital in evaluating a program's effectiveness.

The literature search, however, resulted in very little current research that directly addresses the effectiveness of theological education. Furthermore, research on the effectiveness of undergraduate theological education for pastoral ministry is essentially nonexistent. This research project fills at least one gap revealed in the literature by measuring the perceived effectiveness of five professional ministerial courses taken by theology majors at Southern for ministerial job preparedness. 


\section{CHAPTER 3}

\section{METHODOLOGY}

The purpose of this research study was to evaluate the perceived effectiveness of five professional ministerial courses taken by theology majors at Southern for ministerial job preparedness. This chapter describes the methodology for the study. The approach and rationale for the selection of the design are presented within the context of the research problem and the theoretical framework. The participants, sampling procedure, ethical considerations, instrumentation, variables, data collection, statistical analysis, and limitations are discussed.

\section{Research Design}

The research design that was used for this descriptive study was a parallel mixed methods design, same sample (Tashakkori \& Newman, 2010). The decision for a descriptive study was based on the finding that evaluation of undergraduate theological education had not been studied previously. The mixed methods design allows the integration, comparison, and contrast of quantitative and qualitative data in answering the research questions for this study and formulating a meta inference (Tashakkori \& Newman, 2010). Tashakkori and Teddlie (2008, p. 101) describe a meta inference as "an overall conclusion, explanation or understanding developed through an integration of the inferences obtained from the qualitative and quantitative strands of a mixed method study." The parallel mixed methods design using the same sample involves collecting a 
multiple-question survey with both Likert-style and open-ended questions from the same sample of alumni (Tashakkori \& Newman, 2010). The two types of data in the survey make up the two strands of the study. In addition, the mixed methods design allows a comparison of the senior exit interviews to establish whether they are predictors of perceived effectiveness for ministerial job preparedness. Figure 2 provides a graphic presentation of the research design for this study.

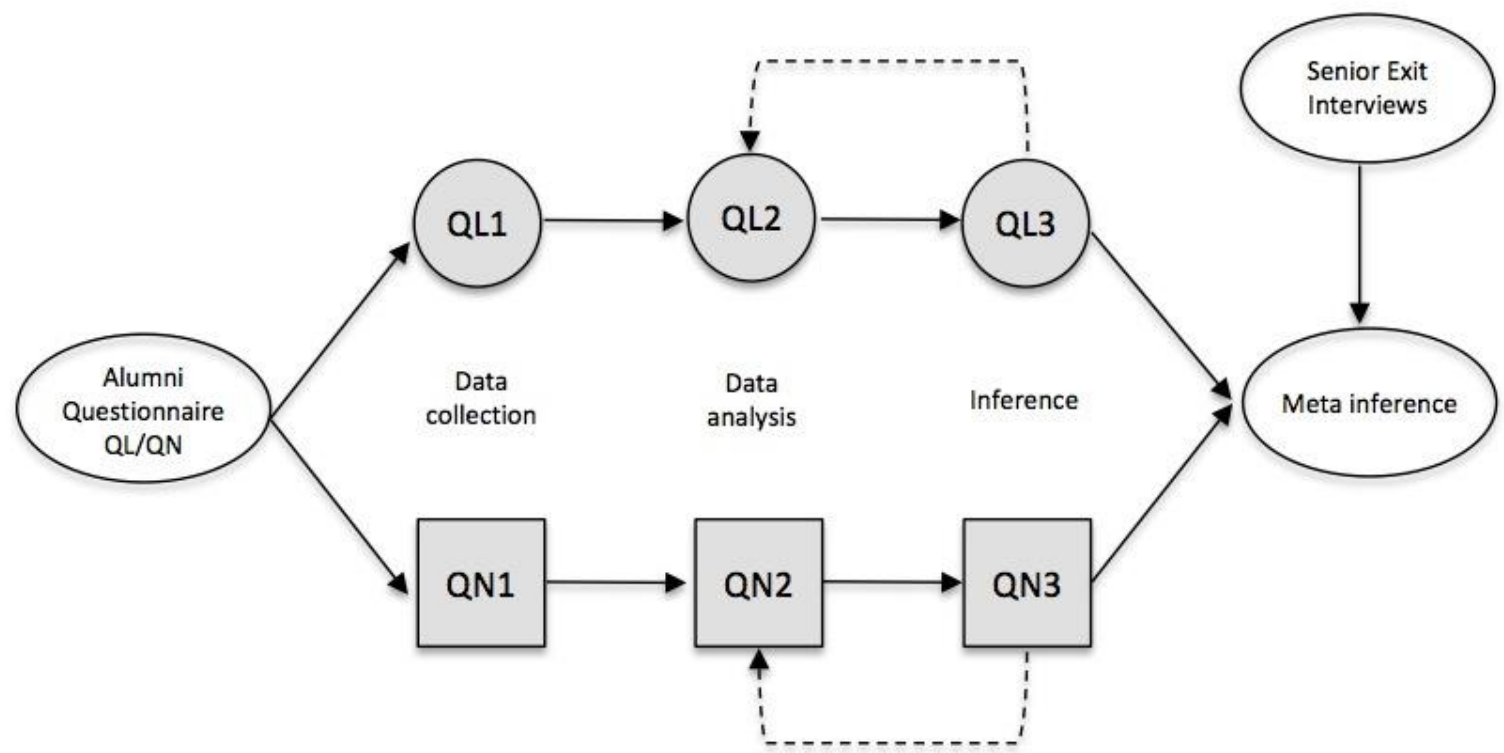

Figure 2. Graphic presentation of research design. Adapted from Tashakkori, A., \& Newman, I. (2010). Mixed methods. In B. McGraw, E. Baker, \& P. Peterson (Eds). International encyclopedia of education ( $3^{\text {rd }} \mathrm{ed}$.). Oxford, England: Elsevier, Ltd.

As one can see from Figure 2, eligible alumni received a questionnaire containing both qualitative (QL) and quantitative (QN) questions. The data was collected (QL1 and QN1). Then the data was analyzed (QL2 \& QN2). As a result of the analysis, inferences (QL3 and QN3) were drawn. The dotted line points out that some of the inferences 
gleaned may bring the researchers back to the data for re-analysis. Lastly, the inferences from both qualitative and quantitative data were integrated into a final meta inference for this study. This meta inference was then compared with the data from the senior exit interviews.

\section{Participants}

A sample of Southern theology graduates was used for this research study. Participants met the following inclusion criteria: (a) alumni of Southern; (b) with a Bachelor of Arts in Theology from Southern; and (c) who graduated between May 2000 and December 2014.

The sources for identifying potential subjects included the alumni database and email list of the SOR at Southern, the alumni association database at Southern, and the records office of Southern (for degree information).

\section{Sample Size}

In order to increase the possibility of finding significance, the sample size was determined by statistical power analysis (McNeil, Newman, \& Kelly, 1996). Using the A-priori Sample Size Calculator for Multiple Regression, a power analysis was conducted using Cohen's $f^{2}$ for a medium size effect of .15, an alpha of .05 , a desired statistical power level of .80 , and five predictors. This yielded a minimum required sample size of 91 (Soper, n.d.).

\section{Sampling Procedures}

A non-probability convenience sample (Creswell, 2012; Doherty, 1994) was used in this study. Although not as strong as a random sample, advantages for this method of 
sampling include lower cost and ease of implementation (Newman \& McNeil, 1998). Alumni who met the eligibility criteria were emailed from the Dean of the SOR at Southern explaining the research study and inviting their participation in this study (see Appendix A). Two email reminders one week apart followed the invitation. A link in the letters directed them to the consent form and survey on Survey Monkey ${ }^{\circledR}$, an online survey software tool. Participation was voluntary. Participants did not receive any incentive or direct benefit from completing the survey.

The generally desired survey response rate in social science research is $80 \%$ (Kerlinger \& Lee, 1999; Newman \& McNeil, 1998). Creswell (2012) maintains that 50\% is acceptable, although the findings are not necessarily good for generalization. Both of these target response rates may be challenging to obtain, however, when the respondent population is alumni. Recent research shows that alumni response rates have been dropping due to factors such as inaccurate contact information, suspicion of money solicitation, and decreased loyalty after graduation (Atrostic, Bates, Burt, \& Silberstein, 2001). Based upon similar results of other alumni surveys (Landrum et al., 2010), a more reasonable response rate of $25 \%$ was predicted for this research study, though these numbers will limit the generalization of findings.

\section{Ethical Considerations}

Applications for research approval were submitted to the Institutional Review Board Committees at Andrews University and Southern (see Appendix A). Prior to completing the online survey, participants were presented with a link providing information about: (a) the purpose of the study; (b) what participation in the study involved; (c) benefits from participation in the study; and (d) confidentiality and 
anonymity issues (see Appendix B). Checkboxes for agree and disagree served as participant consent, and allow them to proceed to the survey questions. There were no foreseeable risks involved in participating in the study.

Confidentiality was carefully protected throughout the study. Participant responses to survey questions were sent to a link at SurveyMonkey.com where data was stored in a password protected electronic format. Survey Monkey ${ }^{\circledR}$ did not collect identifying information such as participant name, email address, or IP address. Therefore, responses remained anonymous. Data was stored electronically on a password-protected computer and backed up to a password-protected folder on the Southern server. Only the researcher had access to the passwords.

All data collected from the exit interviews and surveys were used solely for research purposes. Data analysis was presented in aggregate form only. Individual participants were not identified in publications or presentations.

\section{Instrumentation}

The instrument used in this research was a survey (Creswell, 2012; McMillan \& Schumacher, 2010) consisting of Likert-scale and open-ended questions regarding alumni perceptions of five professional courses in the theology curriculum (see Appendix B). The use of a survey rather than focus groups overcame a significant obstacle in data collection. Since alumni are scattered in other parts of the country and world, their participation in focus groups would be difficult, if not impossible. The use of a survey enabled greater participation by former graduates in this research study. In addition, the survey enabled the researcher to ask questions uniquely related to the educational experience at Southern. 
The survey was divided into four sections. Section 1 contained 12 questions related to demographic information. Section 2 consisted of Likert-scale questions regarding the perceived effectiveness and value of the five courses in the professional curriculum. Respondents were asked to rate the courses on a 4-point scale and rank the courses on a 5-point scale. Rating was done to show which courses were helpful in pastoral preparedness. Ranking was done to help determine which of the courses were perceived as most helpful in preparation for ministry. Open-ended questions provided an opportunity for respondents to explain the reasoning for their scores. In Section 3, 15 additional open-ended questions asked students to share what was most/least helpful about each course and suggestions they might have for these courses. The final section consisted of 12 Likert-scale questions focusing on how well alumni felt that their training at Southern equipped them for specific competencies in pastoral ministry.

Content Validity and Table of Specifications

A Table of Specifications (TOS) was developed using the objectives of the course syllabi (see Appendix C). The purpose of the TOS was to "align a set of items, tasks, or evidence with a set of concepts that are to be assessed" (Newman, Lim, \& Pineda, 2013, p. 244). The TOS was also useful for aligning course content with evaluation tools (Fives \& DiDonato-Barnes, 2013).

In this study, a TOS was developed from the course syllabi of the professional courses to increase the likelihood that the relevant topics outlined in the course syllabi were used in the survey instrument. The TOS was interjudged by the current faculty teaching the five courses and by a small convenience sample of students in their senior year who have taken or are taking those courses. The faculty and students were asked if 
the topics are sufficient to prepare for ministry and, if not, to suggest specific topics that could be added. Their responses were used to help triangulate between course syllabi, teaching faculty, and current students to determine if the topics mentioned in the syllabi are being taught in those courses. The results of the TOS were used to create the items in the third section of the survey tool sent to theology alumni.

\section{Variables}

The independent variables in this study included the following: gender, ethnicity, year of graduation from Southern, and seminary attendance.

Dependent variables included the graduate's perceived rating and ranking of value for five professional ministerial courses taught at Southern: Interpersonal Ministry (RELP270), Personal Evangelism (RELP361 \& RELP362), Evangelistic Preaching and Public Evangelism (RELP405 \& RELP466), Church Ministries (RELP450 \& RELP452), and the Ministerial Externship Program (no course number). See Appendix D for how each variable was coded.

\section{Research Questions}

As previously discussed in Chapter 1, there were six general research questions to guide the research. These research questions were further broken down into more specific subquestions to better address the research topic.

1. Are gender, ethnicity, year of graduation, and seminary attendance individually predictive for how they relate to the five professional ministerial courses studied?

Subquestion 1a. Do gender, ethnicity, year of graduation, and seminary attendance individually predict how well each of the five selected courses are rated? 
Subquestion 1b. Do gender, ethnicity, year of graduation, and seminary attendance individually predict how well each of the five selected courses are ranked?

2. Out of the five professional ministerial courses studied, will there be significantly different ratings in terms of the perceived effectiveness by the graduate in the following variables when controlled for the other variables in the prediction equation: gender, ethnicity, year of graduation, and seminary attendance?

Subquestion 2a. Does gender account for unique variance rating when controlled for ethnicity, year of graduation, and seminary attendance?

Subquestion 2 b. Does ethnicity account for unique variance rating when controlled for gender, year of graduation, and seminary attendance?

Subquestion 2c. Does year of graduation account for unique variance rating when controlled for gender, ethnicity, and seminary attendance?

Subquestion 2d. Does seminary attendance account for unique variance rating when controlled for gender, ethnicity, and year of graduation?

3. Out of the five professional ministerial courses studied, will there be significantly different rankings in terms of the perceived effectiveness by the graduate in the following variables when controlled for the other variables in the prediction equation: gender, ethnicity, year of graduation, and seminary attendance?

Subquestion 3a. Does gender account for unique variance ranking when controlled for ethnicity, year of graduation, and seminary attendance?

Subquestion 3b. Does ethnicity account for unique variance ranking when controlled for gender, year of graduation, and seminary attendance? 
Subquestion 3c. Does year of graduation account for unique variance ranking when controlled for gender, ethnicity, and seminary attendance?

Subquestion 3d. Does seminary attendance account for unique variance ranking when controlled for gender, ethnicity, and year of graduation?

4. For each of the five professional ministerial courses studied, which concepts will be most/least helpful for ministerial job preparedness?

5. For each of the five professional ministerial courses studied, which topics will graduates suggest adding/eliminating, and why?

6. Does the senior exit interview predict future perceived effectiveness of professional ministerial courses for ministerial job preparedness?

\section{Data Collection}

Survey data was collected by use of an online survey by eligible participants through Survey Monkey ${ }^{\circledR}$ during a four-week period in the spring of 2015. In addition, data from exit interviews conducted by the Dean of the SOR from December 2008 through December 2014 were also reviewed. These interviews included the following questions: What are your immediate plans upon graduation? What was most beneficial during your time at Southern? and, How could your experience at Southern have been improved?

\section{Coding}

Posteriori word coding was used to identify patterns of words, phrases, and concepts from the responses to the open-ended questions on the survey instrument. Thematic analysis was then used to further analyze the data by identifying common themes that existed throughout the coded data (Holsti, 1969; Neuendorf, 2002). 


\section{Statistical Analysis}

The Survey Monkey ${ }^{\circledR}$ responses were imported into Microsoft Excel. The dataset was then imported into the IBM ${ }^{\mathrm{TM}}$ Statistical Package for Social Sciences (SPSS) version 22. Data was inspected for outliers and missing data. Outliers, if any, were removed to enhance accuracy of data analysis (Osborne \& Overbay, 2014). In order to not eliminate any cases, missing data was replaced with the linear trend for that point. This method of data transformation uses the theory of regression to calculate coefficients based upon existing values and replaces the missing values with their predicted values (IBM Knowledge Center, 2011). Descriptive data analysis was performed initially to give an overall picture of the dataset. This analysis included mean, standard deviation, and frequency tables. Statistical assumptions were tested, and if violated, non-parametric tests such as Chi Square, were used for inferential analysis.

Spearman rank-order correlation and Pearson's product-moment correlation was used to assess the relationship between variables (Howell, 2010). Two-tailed tests of significance were used to test the relationships of the variables, since the direction of a correlation is uncertain. Multiple regression analysis was used to examine the predictability of the variables (Cohen \& Cohen, 2003; Newman, Benz, Weis, \& McNeil, 1997). Multiple linear regression was chosen because it is more flexible than traditional analysis of variance. With multiple linear regression, one can write the models that reflect the specific research question being asked. Newman, Newman, Brown, and McNeeley (2006) point out that with multiple linear regression one can test relationships between categorical variables, between categorical and continuous variables, or between continuous variables. 
An alpha level of .05 was used to determine whether to accept or reject each hypothesis. The .05 level of significance was used since it is the opinion of the investigator that the consequences of rejecting a research hypothesis are not so serious as to warrant a more stringent confidence level. A power analysis was conducted with a .05 level of significance, a medium size effect of .15, and a sample size of approximately 200 to determine the statistical power of this study.

\section{Limitations}

As with all research, methodological limitations exist and bear mentioning. Following are several limitations that apply to this study:

1. Sample Size: The size of the sample was anticipated to be less than 100 , due to the small number of eligible participants (approximately 200). This may not be representative of alumni theology majors in other Adventist colleges or other university theological education programs. Additionally, an inadequate sample size may limit the ability to detect statistically significant relationships between variables, resulting in a Type II error.

2. Convenience Sample: A convenience sample (Creswell, 2012; McMillan \& Schumacher, 2010) was used in this study, which limits the generalizability of the study findings. In addition, alumni who chose to participate may have differences in demographic data and/or perceptions of the value and effectiveness of the professional courses taken while a student.

3. Self-reported Data: The self-reported data obtained from the alumni surveys could negatively affect the validity of the data by introducing a potential for bias due to selective memory, attribution, and exaggeration. 
4. Incomplete and/or Missing Data: Though missing data can often reduce the representativeness of a sample or distort the conclusions drawn from a study, the few unanswered survey questions in this study did not cause limitations other than decreasing the $n$ for that question.

\section{Summary}

A parallel mixed methods design, same sample, was used for this descriptive study. Independent variables included gender, ethnicity, year of graduation from Southern, and seminary attendance. Dependent variables included the alumni's perceived rating and ranking of value for five professional ministerial courses taught at Southern. A non-probability convenience sample of Southern theology alumni who graduated between May 2000 and December 2014 were asked to complete an online survey consisting of Likert-scale and open-ended questions regarding alumni perceptions of five professional courses in the theology curriculum. In addition, data from exit interviews conducted by the Dean of the SOR from December 2008 through December 2014 were reviewed. Descriptive and inferential statistical analysis, posteriori word coding, and thematic analysis were used to analyze the data. The next chapter outlines the findings from this analysis. 


\section{CHAPTER 4}

\section{FINDINGS}

The purpose of this study was to examine the perceived effectiveness of the undergraduate theological education received by alumni from the SOR at Southern for how well it prepared them for pastoral ministry. It also examined whether demographic variables such as gender, ethnicity, year of graduation, and seminary attendance affected how alumni rated and ranked the five professional courses in their educational program. In addition to quantitative data, open-ended questions were used to better understand why alumni rated and ranked the courses the way they did. This chapter presents an overview of both the quantitative and qualitative findings from alumni responses.

\section{Table of Specifications}

A TOS was used in the development of the survey instrument and to estimate content validity (Newman et al., 2013). The TOS was prepared by examining the syllabi objectives for four of the five professional courses. (There is no syllabus for the Ministerial Externship Program). After reviewing each syllabus, a list of competencies was established and confirmed by each of the professors currently teaching those courses. A survey was then given to current theology majors who had completed the courses and were graduating either in May or December of 2015. Survey answers were tabulated and

can be found in Appendix C. Because there is no syllabus for the Ministerial Externship 
Program, students listed the skills they had learned in their assigned church location with their extern pastor.

Newman et al. (2013) suggested $80 \%$ as a cut off point for content validity agreement in a TOS. Some components in each course fell below $80 \%$ cut-off point (see items marked by $*$ in Tables $1-4)$. While some of these items were not dismissed from the survey to see if they were perceived differently after graduation, one should consider their viability for interpretation for the topic content area. These items should have less weight in interpretation. Based on the student feedback, and some additional items suggested by the current Church Ministries faculty, a final list of pastoral competencies was developed for the survey.

Table 1

Table of Specifications - Church Ministry

\begin{tabular}{lcc}
\hline Topic & \# of Student Responses & \% of Agreement \\
\hline Church Manual & 11 & 91.6 \\
Church Boards & 10 & 83.3 \\
Church Finances & 10 & 83.3 \\
Pastoral Leadership & 11 & 91.6 \\
Involvement in Local Church & 11 & 92.6 \\
Christ's Method of Reaching People & 9 & $75.0 *$ \\
Multi-church Districts & 10 & 83.3 \\
Church Growth & 11 & 91.6 \\
Church Planting & 8 & 66.7 \\
Pastoral Counseling & 11 & 91.6 \\
Membership and Discipline & 11 & 91.6 \\
\hline
\end{tabular}

Note. Total number of seniors responding to the survey were $n=12$.

*Falls below the $80 \%$ cut off. 
Table 2

Table of Specifications_-Evangelistic Preaching and Public Evangelism

\begin{tabular}{lcc}
\hline Topic & \# of Student Responses & \% of Agreement \\
\hline Evangelistic Sermon Preparation & 11 & 91.6 \\
Church Revival Sermon Preparation & 5 & $41.7^{*}$ \\
Using A/V in Evangelism & 10 & 83.3 \\
Preparing for Evangelistic Meetings & 9 & $75.0^{*}$ \\
Visitation & 9 & $75.0^{*}$ \\
Meeting Organization & 4 & $33.3^{*}$ \\
Gaining Decisions & 11 & 91.6 \\
Evangelism Cycle & 10 & 83.3 \\
Preparing People for Baptism & 10 & 83.3 \\
\hline
\end{tabular}

Note. Total number of seniors responding to the survey were $n=12$.

*Falls below the $80 \%$ cut off.

Table 3

Table of Specifications-Interpersonal Ministry

\begin{tabular}{lcc}
\hline Topic & \# of Student Responses & \% of Agreement \\
\hline Listening Skills & 11 & 91.6 \\
Interpersonal Skills & 12 & 100 \\
Communication Skills & 12 & 100 \\
Member Visitation & 7 & $58.3^{*}$ \\
Inactive Visitation & 5 & $42.6^{*}$ \\
Hospital Visitation & 5 & $42.6^{*}$ \\
Conflict Resolution & 10 & 83.3 \\
\hline
\end{tabular}

Note. Total number of seniors responding to the survey were $n=12$.

*Falls below the $80 \%$ cut off. 
Table 4

Table of Specifications-Personal Evangelism

\begin{tabular}{lcc}
\hline Topic & \# of Student Responses & \% of Agreement \\
\hline Give Bible Studies & 12 & 100 \\
Personal Evangelism Skills & 11 & 91.6 \\
Friendship Evangelism & 12 & 100 \\
Personal Testimony & 8 & $66.7^{*}$ \\
Soul-Winning Strategies & 10 & 88.3 \\
Small Group Ministry & 11 & 91.6 \\
Evangelistic Visitation & 10 & 88.3 \\
Gaining Evangelistic Decisions & 11 & 91.6 \\
Evangelistic Appeals for Decisions & 9 & $75.0^{*}$ \\
Evangelistic Cycle & 11 & 91.6 \\
Spiritual Gifts & 6 & $66.7^{*}$ \\
Give Testimony & 10 & 88.3 \\
Gospel Presentation & 12 & 100 \\
Biblical Objections & 11 & 91.6 \\
Appeals for decisions & 11 & 91.6 \\
\hline
\end{tabular}

Note. Total number of seniors responding to the survey were $n=12$.

*Falls below the $80 \%$ cut off.

Graduating seniors were also asked, "What percent do you think these topics are sufficient for this course?" This was based on a scale of $0-100$. Each of the five professional courses were given scores above $85 \%$, with Personal Evangelism scoring the highest at $94.6 \%$ and Evangelistic Preaching and Public Evangelism scoring the lowest at $85.8 \%$ (see Table 5).

Based on the TOS and faculty input, a list of 22 pastoral competences was included in the research survey: Counseling (basic skills), Counseling (advanced skills), Conflict Resolution, Public Evangelism, Personal Evangelism, Leadership Skills, 
Table 5

Table of Specifications-Percent of Topic Sufficiency

\begin{tabular}{lc}
\hline Variable & \% of Agreement \\
\hline Church Ministry & 89.6 \\
Evangelistic Preaching and Public Evangelism & 85.8 \\
Externship Program & 90.0 \\
Interpersonal Ministries & 87.5 \\
Personal Evangelism & 94.6 \\
\hline
\end{tabular}

Note. Total number of seniors responding to the survey were $n=12$.

Interpersonal Communication Skills, Church Management, Vision Casting, Visitation, Church Board, Church Finances, Small Group Ministry, Youth Ministry, Children's Ministry, Church Growth, Discipleship, Personal Spiritual Growth, Empowering Leadership, Worship Services (plan/lead), Special Services (baptisms and funerals), and Volunteer Management/Placement.

\section{Data Preparation and Management}

Survey Monkey ${ }^{\circledR}$ was used to create the survey questionnaire. An email was sent to alumni who fit the criteria for this study: an alumnus of Southern who graduated with a theology degree from the SOR between May 2000 and December of 2014. The email consisted of a letter of introduction from the Dean of the SOR along with an invitation to participate in the study and a Survey Monkey ${ }^{\circledR}$ link that would direct participants to the survey. Two reminders were sent out by email at one-week intervals. The survey was closed at the end of three weeks. The results of the survey were imported into SPSS version 22 . 


\section{Description of Sample}

The Office of Alumni at Southern provided 223 names that fit the criteria of this study. All were alumni who had graduated with a theology degree between May 2000 and December 2014. The survey was open for three weeks. Two email reminders, a week apart, were sent to each of the alumni encouraging participation in this study. There was a total of 76 responses to the survey (a response rate of $34 \%$ ).

Over 90 percent of the respondents were male (90.8\%). Fifty-three percent identified themselves as White, Non-Hispanic, 33\% as Hispanic/Latino, 5\% as African American, 5\% Asian, and 2\% marked "Other." The marital status of the respondents was 75\% married and 25\% single. Those who graduated during 2000-2005 were 32.8\%, during 2006-2010 were 28.6\%, and during 2011-2014 were 38\% (see Table 6).

Participants were asked to indicate their graduation date from Southern. The responses were evenly distributed, with $32.9 \%$ graduating during the years 2000-2005, $29 \%$ during the years 2006-2010, and 38.1\% during the years 2001-2014. There were two questions on seminary attendance. Forty-six percent had not attended seminary, $6 \%$ attended seminary unsponsored (self-paying tuition) and $47 \%$ attended seminary sponsored by an employing conference. As to when participants attended seminary, $25.3 \%$ attended seminary immediately upon graduation while $29.3 \%$ attended seminary after working in a pastoral district (see Table 7).

Conference sponsorship was another question on the survey. The largest group $(53.3 \%)$ was those who received a full-time job offer before graduation. Twenty percent did not receive a job offer for pastoral ministry, $17.3 \%$ received a job offer for pastoral ministry within six months of graduation, and $4 \%$ received a job offer more than 12 months after graduation (see Table 8). 
Table 6

Gender, Ethnicity, and Marital Status

\begin{tabular}{lcc}
\hline Variable & $n$ & $\%$ \\
\hline Gender & 69 & \\
Male & 7 & 90.8 \\
Female & & \\
Ethnicity & 40 & 53.3 \\
White, Non-Hispanic & 25 & 33.3 \\
Hispanic/Latino & 4 & 5.3 \\
African American & 4 & 5.3 \\
Asian & 2 & 2.7 \\
Other & & \\
Marital Status & & 25 \\
Single & 19 & 75 \\
Married & 57 & 0 \\
Separated & 0 & 0 \\
Divorced & 0 & 0 \\
Widowed & 0 & \\
\hline
\end{tabular}

Fifty-one percent of the participants indicated that they had attended an Adventist elementary school and 56\% had attended an Adventist high school (see Table 9). Sixty-three percent are currently pastoring an Adventist church. Eighty-one percent indicated that the undergraduate education they received at Southern equipped them for pastoral ministry. When asked if they would repeat their theological education again at Southern, $80 \%$ indicated that they would (see Table 10).

\section{Rating and Ranking of Professional Courses}

Participants were asked to rate five professional courses (Church Ministry, Evangelistic Preaching and Public Evangelism, Externship Program, Interpersonal 
Table 7

Graduation Year, Seminary Attendance, Time of Seminary Attendance

\begin{tabular}{lcc}
\hline Variable & $n$ & $\%$ \\
\hline Graduation Year & & \\
2000-2005 & 25 & 32.9 \\
$2006-2010$ & 22 & 29.0 \\
$2011-2014$ & 29 & 38.2 \\
Seminary Attendance & & \\
Have not attended seminary & 35 & 46.1 \\
Attended seminary (unsponsored) & 5 & 6.6 \\
Attended seminary (sponsored) & 36 & 47.3 \\
Seminary (Time) & & \\
Have not attended seminary & 34 & 45.3 \\
Attended seminary immediately upon graduation & 19 & 25.3 \\
Attended seminary after working in a pastoral district & 22 & 29.3 \\
\hline
\end{tabular}

Table 8

Conference Sponsorship

\begin{tabular}{lcc}
\hline Variable & $n$ & $\%$ \\
\hline No job offer & 15 & 20.0 \\
Job offer after 12 months & 3 & 4.0 \\
Job offer within 6 months & 13 & 17.3 \\
Job offer before graduation & 40 & 53.3 \\
Other & 4 & 5.3 \\
\hline
\end{tabular}


Table 9

Elementary and High School Education

\begin{tabular}{lll}
\hline Variable & $n$ & $\%$ \\
\hline Grade School Education & & \\
$\quad$ I did not attend Adventist grade school & 37 & 46.7 \\
$\quad$ I attended an Adventist grade school & 39 & 51.3 \\
High School Education & & \\
$\quad$ I did not attend an Adventist high school & 33 & 43.4 \\
I attended an Adventist high school & 43 & 56.6 \\
\hline
\end{tabular}

Table 10

Currently Pastoring, Degree at SAU Again, Perception of SAU Undergraduate Training

\begin{tabular}{lcc}
\hline Variable & $n$ & $\%$ \\
\hline Currently Pastoring an Adventist Church & & \\
$\quad$ No & 28 & 36.8 \\
$\quad$ Yes & 48 & 63.2 \\
Degree at SAU Again & 4 & 5.3 \\
$\quad$ No & 11 & 14.7 \\
Unsure & 60 & 80 \\
$\quad$ Yes & & \\
Perception of SAU Undergraduate Training & 2 & 2.9 \\
$\quad$ Did not help at all & 3 & 4.3 \\
$\quad$ Different training would have been more & & 11.4 \\
helpful & 8 & 52.9 \\
$\quad$ More training would have been helpful & 37 & 28.6 \\
$\quad$ Parts of training were useful and parts were not & 20 & \\
It has been really useful & & \\
\hline
\end{tabular}


Ministry, and Personal Evangelism), indicating how helpful each was in preparation for pastoral ministry (see Table 11). The response options on the four-point Likert scale included not helpful, somewhat helpful, very helpful, and extremely helpful. The highest rated course was Interpersonal Ministry, with $85.7 \%$ indicating the course as very helpful or extremely helpful. Personal Evangelism was the lowest rated course, with over half (56.2\%) indicating not helpful or somewhat helpful.

The same professional courses were also ranked from most to least helpful in preparation for pastoral ministry, with 1 being the highest ranking and 5 the lowest ranking. Thirty-three percent (33.8\%) reported Interpersonal Ministry as the top ranked course. Personal Evangelism was the lowest ranked course (38\%) (see Table 12).

\section{Correlation for Rating of Professional Courses}

A point bi-serial correlation was run on the question about rating the five courses and their perceived effectiveness of pastoral preparation. All of the variables were binary coded ( 1 if male, 0 if other; 1 if Hispanic/Latino, 0 if other; etc.) making the $n$ a total of the respondents. Male alumni scored significantly higher than females when rating Personal Evangelism $(r=.34, p<.05)$. White, Non-Hispanic scored significantly lower $(r=-.25, p<.05)$ than other ethnic groups and Hispanic/Latino alumni scored significantly higher $(r=.29 . p<.05)$ than other ethnic groups when rating Personal Evangelism. There were no other statistical differences between gender, ethnicity, year of graduation, or seminary attendance in the rating of the five professional courses (see Table 13). 
Table 11

Rating of Professional Courses

\begin{tabular}{|c|c|c|}
\hline Variable & $n$ & $\%$ \\
\hline \multicolumn{3}{|l|}{ Church Ministry } \\
\hline Not helpful & 2 & 2.9 \\
\hline Somewhat helpful & 20 & 28.6 \\
\hline Very helpful & 32 & 45.7 \\
\hline Extremely helpful & 16 & 22.9 \\
\hline \multicolumn{3}{|c|}{ Evangelistic Preaching and Public Evangelism } \\
\hline Not helpful & 6 & 8.8 \\
\hline Somewhat helpful & 20 & 29.4 \\
\hline Very helpful & 22 & 32.4 \\
\hline Extremely helpful & 20 & 29.4 \\
\hline \multicolumn{3}{|l|}{ Externship Program } \\
\hline Not helpful & 12 & 8.8 \\
\hline Somewhat helpful & 15 & 29.4 \\
\hline Very helpful & 15 & 32.4 \\
\hline Extremely helpful & 25 & 29.4 \\
\hline \multicolumn{3}{|l|}{ Interpersonal Ministry } \\
\hline Not helpful & 0 & 0 \\
\hline Somewhat helpful & 10 & 14.3 \\
\hline Very helpful & 26 & 37.1 \\
\hline Extremely helpful & 34 & 48.6 \\
\hline \multicolumn{3}{|l|}{ Personal Evangelism } \\
\hline Not helpful & 8 & 11.6 \\
\hline Somewhat helpful & 31 & 44.9 \\
\hline Very helpful & 16 & 23.2 \\
\hline Extremely helpful & 14 & 20.3 \\
\hline
\end{tabular}


Table 12

Ranking of Professional Courses

\begin{tabular}{|c|c|c|}
\hline Variable & $n$ & $\%$ \\
\hline \multicolumn{3}{|c|}{ Church Ministry } \\
\hline Ranked $1^{\text {st }}$ & 15 & 21.1 \\
\hline Ranked $2^{\text {nd }}$ & 19 & 26.8 \\
\hline Ranked $3^{\text {rd }}$ & 21 & 29.6 \\
\hline Ranked $4^{\text {th }}$ & 10 & 14.1 \\
\hline Ranked $5^{\text {th }}$ & 6 & 8.5 \\
\hline \multicolumn{3}{|c|}{ Evangelistic Preaching and Public Evangelism } \\
\hline Ranked $1^{\text {st }}$ & 10 & 14.1 \\
\hline Ranked $2^{\text {nd }}$ & 10 & 14.1 \\
\hline Ranked $3^{\text {rd }}$ & 16 & 22.5 \\
\hline Ranked $4^{\text {th }}$ & 19 & 26.8 \\
\hline Ranked $5^{\text {th }}$ & 16 & 22.5 \\
\hline \multicolumn{3}{|c|}{ Externship Program } \\
\hline Ranked $1^{\text {st }}$ & 19 & 26.8 \\
\hline Ranked $2^{\text {nd }}$ & 16 & 22.5 \\
\hline Ranked $3^{\text {rd }}$ & 9 & 12.7 \\
\hline Ranked $4^{\text {th }}$ & 6 & 8.5 \\
\hline Ranked $5^{\text {th }}$ & 21 & 29.6 \\
\hline \multicolumn{3}{|c|}{ Interpersonal Ministry } \\
\hline Ranked $1^{\text {st }}$ & 24 & 33.8 \\
\hline Ranked $2^{\text {nd }}$ & 21 & 29.6 \\
\hline Ranked $3^{\text {rd }}$ & 13 & 18.3 \\
\hline Ranked $4^{\text {th }}$ & 12 & 16.9 \\
\hline Ranked $5^{\text {th }}$ & 1 & 1.4 \\
\hline \multicolumn{3}{|c|}{ Personal Evangelism } \\
\hline Ranked $1^{\text {st }}$ & 3 & 4.2 \\
\hline Ranked $2^{\text {nd }}$ & 5 & 7.0 \\
\hline Ranked $3^{\text {rd }}$ & 12 & 16.9 \\
\hline Ranked $4^{\text {th }}$ & 24 & 33.8 \\
\hline Ranked $5^{\text {th }}$ & 27 & 38.0 \\
\hline
\end{tabular}


Table 13

Point Bi-Serial Correlation for Rating of Professional Courses

\begin{tabular}{|c|c|c|c|c|c|}
\hline Variable & $\begin{array}{l}\text { Church } \\
\text { Ministry }\end{array}$ & $\begin{array}{c}\text { Evangelistic } \\
\text { Preaching }\end{array}$ & Externship & $\begin{array}{c}\text { Interpersonal } \\
\text { Ministry }\end{array}$ & $\begin{array}{c}\text { Personal } \\
\text { Evangelism }\end{array}$ \\
\hline \multicolumn{6}{|l|}{ Male } \\
\hline$r$ & .15 & .11 & .17 & .00 & $.34 * *$ \\
\hline$n$ & 70 & 68 & 67 & 70 & 69 \\
\hline$p$ & .21 & .39 & .16 & .97 & $.01 * *$ \\
\hline \multicolumn{6}{|c|}{ White, Non-Hispanic } \\
\hline$r$ & -.20 & -.07 & -.14 & -.04 & $-.25^{*}$ \\
\hline$n$ & 69 & 67 & 66 & 69 & 68 \\
\hline$p$ & .11 & .57 & .28 & .77 & $.04 *$ \\
\hline \multicolumn{6}{|c|}{ Hispanic/Latino } \\
\hline$r$ & .21 & -.04 & .18 & .09 & $.29 *$ \\
\hline$n$ & 69 & 67 & 66 & 69 & 68 \\
\hline$p$ & .08 & .75 & .16 & .49 & $.02 *$ \\
\hline \multicolumn{6}{|c|}{ African American } \\
\hline$r$ & .03 & .18 & -.15 & -.12 & -.01 \\
\hline$n$ & 69 & 67 & 66 & 69 & 68 \\
\hline$p$ & .79 & .16 & .23 & .33 & .95 \\
\hline \multicolumn{6}{|l|}{ Asian } \\
\hline$r$ & -.06 & .04 & -.09 & -.10 & -.04 \\
\hline$n$ & 69 & 67 & 66 & 69 & 68 \\
\hline$p$ & .61 & .77 & .50 & .40 & .72 \\
\hline \multicolumn{6}{|c|}{ Other Ethnicity } \\
\hline$r$ & .02 & .03 & .19 & .16 & -.01 \\
\hline$n$ & 69 & 67 & 66 & 69 & 68 \\
\hline$p$ & .86 & .81 & .12 & .20 & .97 \\
\hline \multicolumn{6}{|c|}{ 2000-2005 } \\
\hline$r$ & -.13 & -.03 & -.10 & -.09 & .05 \\
\hline$n$ & 70 & 68 & 67 & 70 & 69 \\
\hline$p$ & .30 & .84 & .41 & .44 & .70 \\
\hline \multicolumn{6}{|c|}{ 2006-2010 } \\
\hline$r$ & -.10 & .06 & .04 & -.14 & -.13 \\
\hline$n$ & 70 & 68 & 67 & 70 & 69 \\
\hline$p$ & .40 & .65 & .75 & .25 & .28 \\
\hline \multicolumn{6}{|c|}{ 2011-2014 } \\
\hline$r$ & .22 & -.03 & .06 & .23 & .08 \\
\hline$n$ & 70 & 68 & 67 & 70 & 69 \\
\hline$p$ & .06 & .80 & .62 & .06 & .51 \\
\hline
\end{tabular}


Table 13-Continued

\begin{tabular}{lccccc}
\hline Variable & $\begin{array}{c}\text { Church } \\
\text { Ministry }\end{array}$ & $\begin{array}{c}\text { Evangelistic } \\
\text { Preaching }\end{array}$ & Externship & $\begin{array}{c}\text { Interpersonal } \\
\text { Ministry }\end{array}$ & $\begin{array}{c}\text { Personal } \\
\text { Evangelism }\end{array}$ \\
\hline $\begin{array}{ccccc}\text { No Seminary } \\
r\end{array}$ & .20 & -.17 & -.00 & .12 & -.11 \\
$n$ & 70 & 68 & 67 & 70 & 69 \\
$p$ & .10 & .18 & .97 & .31 & .36 \\
Seminary Unsponsored & & & & \\
$r$ & -.10 & -.13 & -.12 & -.21 & -.04 \\
$n$ & 70 & 68 & 67 & 70 & 69 \\
$p$ & .41 & .31 & .33 & .08 & .77 \\
Seminary Sponsored & -.14 & .23 & .06 & -.01 & .13 \\
$r$ & 70 & 68 & 67 & 70 & 69 \\
$n$ & .24 & .06 & .62 & .91 & .29 \\
$p$ & & & & & \\
\hline
\end{tabular}

Note. The $p$-value associated with this point bi-serial $\mathrm{r}$ is equal to the $p$-value associated with the $t$-test. See coding in Appendix D. To correct for a Type 1 error rate build up, a Bonferroni procedure was used to keep the alpha level at .05. A pvalue of $\leq .005$ will be used.

* Correlation is significant at the 0.05 level (2-tailed).

** Correlation is significant at the 0.01 level (2-tailed).

\section{Regression Analysis for Rating of Professional Courses}

Alumni were asked to rate the five professional courses on their perception of how those courses prepared them for ministry. A regression analysis was conducted to examine any predictions in any of the ratings of the five professional courses (see Appendix E). Two were found to be statistically significant: Personal Evangelism and Evangelistic Preaching and Public Evangelism.

When the rating of Personal Evangelism was predicted it was found that females $(\beta=-.45, p<.05)$ and those graduating during 2006-2010 $(\beta=-.32, p<.05)$ accounted for a significant amount of unique variance with a $p$ value of $\leq .01$ for females and .03 for 
those graduating during 2006-2010. The overall model fit was $R^{2}=.27\left(F_{(1,8)(9,58)}=2.36\right.$, $p<.05)($ see Table 14).

Table 14

Summary of Linear Regression Analysis for Variables Predicting Rating of Personal Evangelism $(N=67)$

\begin{tabular}{lccccc}
\hline Variable & $B$ & $S E B$ & $\beta$ & $t$ & $p$ \\
\hline Female & -1.50 & .45 & $-.45^{*}$ & -3.33 & $.00^{*}$ \\
Hispanic/Latino & .43 & .24 & .21 & 1.75 & .09 \\
African American & .78 & .50 & .19 & 1.56 & .12 \\
Asian & .34 & .54 & .08 & .64 & .53 \\
Other Ethnicity & -.29 & .66 & -.05 & -.43 & .67 \\
Graduated 2000-2005 & -.36 & .30 & -.18 & -1.21 & .23 \\
Graduated 2006-2010 & -.67 & .30 & $-.32 *$ & -2.25 & $.03 *$ \\
Attended Seminary Unsponsored & .24 & .45 & .07 & .54 & .59 \\
Attended Seminary Sponsored & .40 & .25 & .21 & 1.62 & .11 \\
\hline
\end{tabular}

Note. Male, White, Non-Hispanic, Graduated 2011-2014, No Seminary Attendance excluded. See coding in Appendix D. To correct for a Type 1 error rate build up, a Bonferroni procedure was used to keep the alpha level at .05. A $p$-value of $\leq .005$ will be used.

$F=2.36, R^{2}=.27, p<05$.

When the rating for Evangelistic Preaching and Public Evangelism was predicted, it was found that African Americans $(\beta=.29, p<.05)$ was a significant predictor and accounted for a significant amount of unique variance with a $p$-value of .04 independent 
of the other variables. The overall model fit was $R^{2}=.15\left(F_{(9,57)}=1.15, p>.05\right)($ see Table 15).

Table 15

Summary of Linear Regression Analysis for Variables Predicting Rating of Evangelistic Preaching and Public Evangelism $(N=66)$

\begin{tabular}{lccccc}
\hline Variable & $B$ & $S E B$ & $\beta$ & $t$ & $p$ \\
\hline Female & -.78 & .49 & -.23 & -1.58 & .12 \\
Hispanic/Latino & -.11 & .27 & -.06 & -.43 & .67 \\
African American & 1.17 & .54 & $.29 *$ & 2.15 & $.04 *$ \\
Asian & .30 & .59 & .07 & .51 & .61 \\
Other Ethnicity & -.13 & .72 & -.02 & -.18 & .86 \\
Graduated 2006-2010 & .14 & .30 & .07 & .47 & .64 \\
Graduated 2011-2014 & .27 & .32 & .13 & .82 & .42 \\
Attended Seminary Unsponsored & -.21 & .49 & -.06 & -.44 & .66 \\
Attended Seminary Sponsored & .52 & .27 & .27 & 1.93 & .06 \\
\hline
\end{tabular}

Note. Male, White, Non-Hispanic, Graduated 2000-2005, No Seminary Attendance excluded. See coding in Appendix D. To correct for a Type 1 error rate build up, a Bonferroni procedure was used to keep the alpha level at .05. A $p$-value of $\leq .005$ will be used.

$F=1.15, R^{2}=.15, p<.05^{*}$.

\section{Chi-Square Analysis for Rating of Professional Courses}

Alumni were asked to rate each of the five professional courses for its helpfulness in preparation for ministry on a 1-4 scale (not helpful, somewhat helpful, very helpful, extremely helpful). Chi-Square tests were conducted to determine whether any variables 
(gender, ethnicity, year of graduation, and seminary attendance) occurred with a greater frequency than would be expected by chance (see Appendix E).

Because of the insufficient $n$ for gender (female $=7$ ) and ethnicity (African American $=4$, Asian $=4$, Other $=4$ ), the numbers were too small to run an analysis on those variables. For ethnicity, the analysis was done between the two largest groups, White, Non-Hispanic and Hispanic/Latino. The only significance $(p=.01)$ noted was in the year of graduation and the rating of the Externship Program (see Table 16).

A Chi-Square was run on the three different graduation groups (2000-2005, 2006-2010, and 2011-2014) to control for the year of graduation. There was a significant difference in the ratings of the Externship Program between those who graduated during 2000-2005 and the other two groups $(p=.01)$, and a significant difference between those who graduated during 2011-2014 and the other two groups ( $p$ $=.04)$. According to the data, those who graduated during 2000-2005 rated the Externship Program higher than those who did not graduate during 2000-2005 (see Table 17). In addition, it was found that those who graduated during 2011-2014 rated the Externship Program higher than those did not graduate during 2011-2014 (see Table 18). There was no significant difference noted in the ratings of the Externship Program between those who graduated during 2006-2010 and those who did not graduate during 2006-2010 $(p=.12)$ (see Table 19).

\section{Correlation for Ranking of Professional Courses}

The results of the correlation for the ranking of the five professional courses showed that African-American alumni scored significantly higher $(r=.29, p<.05)$ than other ethnic groups for Personal Evangelism. There were no other statistical differences 
Table 16

Year of Graduation and Rating of Externship Program

\begin{tabular}{lcc}
\hline Variable & $n$ & $\%$ \\
\hline $2000-2005$ & 7 & 33.3 \\
Not helpful & 4 & 19.0 \\
Somewhat helpful & 0 & 0.00 \\
Very helpful & 10 & 47.6 \\
Extremely helpful & & \\
2006-2010 & 4 & 19.0 \\
Not helpful & 2 & 9.5 \\
Somewhat helpful & 8 & 38.1 \\
Very helpful & 7 & 33.3 \\
Extremely helpful & & \\
2011-2014 & 1 & 4.0 \\
Not helpful & 9 & 36.0 \\
Somewhat helpful & 7 & 28.0 \\
Very helpful & 8 & 32.0 \\
Extremely helpful & & \\
\hline Note. See coding in Appendix D. To & \\
\hline
\end{tabular}

Note. See coding in Appendix D. To correct for a Type 1 error rate build up, a Bonferroni procedure was used to keep the alpha level at .05. A $p$-value of $\leq .016$ will be used.

$\chi^{2}=17.47, p=.01$ 
Table 17

Graduating 2000-2005 and Rating of Externship Program

\begin{tabular}{lcc}
\hline Variable & $n$ & $\%$ \\
\hline 2000-2005 & 7 & \\
Not helpful & 4 & 33.3 \\
Somewhat helpful & 0 & 19.0 \\
Very helpful & 10 & .00 \\
Extremely helpful & & 47.6 \\
Not 2000-2005 & 5 & \\
Not helpful & 11 & 10.9 \\
Somewhat helpful & 15 & 23.9 \\
Very helpful & 15 & 32.6 \\
Extremely helpful & & 32.6 \\
\hline
\end{tabular}

Note. See coding in Appendix D.

$\chi^{2}=11.93, p=.01$

between gender, ethnicity, year of graduation, or seminary attendance in the ranking of the five professional courses (see Table 20).

\section{Regression Analysis for Ranking of Professional Courses}

In addition to rating the five professional courses, alumni were asked to rank those same courses on their perception of how those courses prepared them for ministry. A regression analysis was conducted to examine any predictions in any of the rankings of the five professional courses (see Appendix E). When the ranking of Personal Evangelism was predicted, it was found that the African American ethnicity ( $\beta$ $=.33, p<.05$ ) was a significant predictor and accounted for a significant amount of 
Table 18

Graduating 2011-2014 and Rating of Externship Program

\begin{tabular}{lcc}
\hline Variable & $n$ & $\%$ \\
\hline 2011-2014 & 1 & \\
Not helpful & 9 & 4.0 \\
Somewhat helpful & 7 & 36.0 \\
Very Helpful & 8 & 28.0 \\
Extremely helpful & & 32.0 \\
Not 2011-2015 & 11 & \\
Not helpful & 6 & 26.2 \\
Somewhat helpful & 8 & 14.3 \\
Very Helpful & 17 & 19.0 \\
Extremely helpful & & 40.5 \\
\hline
\end{tabular}

Note. See coding in Appendix D.

$\chi^{2}=18.48, p=.04$

unique variance with a $p$-value of .03 independent of the other variables. The overall model fit was $R^{2}=.18\left(F_{(9,48)}=1.16 ; p>.05\right)$ (see Table 21$)$.

Chi-Square Analysis for Ranking of Professional Courses

Alumni were also asked to rank each of the five professional courses for its helpfulness in preparation for ministry from most helpful to least helpful. They were only allowed to choose one course for each of the rankings (Most Helpful, $2^{\text {nd }}$ Most Helpful, $3^{\text {rd }}$ Most Helpful, $4^{\text {th }}$ Most Helpful, $5^{\text {th }}$ Most Helpful). Chi-Square tests were run for each variable (gender, ethnicity, year of graduation, and seminary attendance) to determine if any variable occurred with a greater frequency than one would expect by chance (see 
Table 19

Graduating 2006-2010 and Rating of Externship Program

\begin{tabular}{lcc}
\hline Variable & $n$ & $\%$ \\
\hline 2006-2010 & 4 & \\
Not helpful & 2 & 19.0 \\
Somewhat helpful & 8 & 9.5 \\
Very Helpful & 7 & 38.1 \\
Extremely helpful & & 33.3 \\
Not 2006-2010 & 8 & \\
Not helpful & 13 & 17.4 \\
Somewhat helpful & 7 & 28.3 \\
Very Helpful & 18 & 15.2 \\
Extremely helpful & & 39.1 \\
\hline
\end{tabular}

Note. See coding in Appendix D.

$\chi^{2}=5.78, p=.12$

Appendix E). Because of the insufficient $n$ for gender (female $=7$ ) and ethnicity (African American $=4$, Asian $=4$, Other $=4$ ) the numbers were too small to run an analysis on those variables. For ethnicity, the analysis was done between the two largest groups, White, Non-Hispanic, and Hispanic/Latino. There was no statistical significance noted between any of the variables.

\section{Perception of Preparedness for Pastoral Competencies}

Alumni were asked to indicate how prepared they were for each of the 22 pastoral competencies upon graduating from Southern (see Appendix E). The competences that alumni scored as "Very prepared" or "More than adequately prepared," based on a 
Table 20

Point Bi-Serial Correlation for Ranking of Professional Courses

\begin{tabular}{lccccc}
\hline Variable & $\begin{array}{c}\text { Church } \\
\text { Ministry }\end{array}$ & $\begin{array}{c}\text { Evangelistic } \\
\text { Preaching }\end{array}$ & Externship & $\begin{array}{c}\text { Interpersonal } \\
\text { Ministry }\end{array}$ & $\begin{array}{c}\text { Personal } \\
\text { Evangelism }\end{array}$ \\
\hline Male & & & & & \\
$r$ & -.04 & .02 & .04 & -.02 & -.03 \\
$n$ & 50 & 55 & 62 & 58 & 59 \\
$p$ & .76 & .91 & .74 & .90 & .82
\end{tabular}

White, Non-Hispanic

$\begin{array}{lccccc}r & .04 & .15 & -.19 & .05 & -.01 \\ n & 50 & 54 & 61 & 57 & 58 \\ p & .81 & .27 & .15 & .70 & .92\end{array}$

Hispanic/Latino

$\begin{array}{lccccc}r & .14 & -.19 & .16 & .05 & -.09 \\ n & 50 & 54 & 61 & 57 & 58 \\ p & .32 & .17 & .22 & .72 & .49\end{array}$

African American

$r$
$n$
$p$

$-.21$

$50 \quad 54$

.10

$-.25$

$.29 *$

.15

61

57

58

.59

.43

.07

$.03 *$

Asian

$\begin{array}{lcc}r & -.01 & .05 \\ n & 50 & 54 \\ p & .96 & .71\end{array}$

.05

$-.02$

$-.06$

$-.08$

61

58

.87

57

.57

Other Ethnicity

$\begin{array}{lccccc}r & -.08 & -.11 & -.02 & .10 & -.05 \\ n & 50 & 54 & 61 & 57 & 58 \\ p & .59 & .45 & .87 & .44 & .69 \\ 2000-2005 & & & & & \\ r & .16 & .18 & -.16 & -.13 & -.14 \\ n & 50 & 55 & 62 & 58 & 59 \\ p & .28 & .18 & .22 & .32 & .28 \\ 2006-2010 & & & & & \\ r & .02 & -.12 & .25 & .05 & .07 \\ n & 50 & 55 & 62 & 58 & 59 \\ p & .91 & .37 & .05 & .69 & .58\end{array}$


Table 20-Continued

\begin{tabular}{lccccc}
\hline Variable & $\begin{array}{c}\text { Church } \\
\text { Ministry }\end{array}$ & $\begin{array}{c}\text { Evangelistic } \\
\text { Preaching }\end{array}$ & Externship & $\begin{array}{c}\text { Interpersonal } \\
\text { Ministry }\end{array}$ & $\begin{array}{c}\text { Personal } \\
\text { Evangelism }\end{array}$ \\
\hline $2011-2014$ & & & & & \\
$r$ & -.17 & -.07 & -.07 & .08 & .21 \\
$n$ & 50 & 55 & 62 & 58 & 59 \\
$p$ & .24 & .62 & .57 & .55 & .12 \\
No Seminary & & & & & \\
$r$ & .10 & -.05 & -.15 & .00 & .15 \\
$n$ & 50 & 55 & 62 & 58 & 59 \\
$p$ & .51 & .72 & .25 & .98 & .27 \\
Seminary Unsponsored & & & & \\
$r$ & -.01 & .02 & -.03 & .02 & -.09 \\
$n$ & 50 & 55 & 62 & 58 & 59 \\
$p$ & .96 & .86 & .79 & .90 & .49 \\
Seminary Sponsored & & & & & \\
$r$ & -.09 & .03 & .16 & -.01 & -.11 \\
$n$ & 50 & 55 & 62 & 58 & 59 \\
$p$ & .54 & .80 & .21 & .92 & .43 \\
\hline
\end{tabular}

Note. The $p$-value associated with this point bi-serial $\mathrm{r}$ is equal to the $p$-value associated with the $t$-test. See coding in Appendix D. To correct for a Type 1 error rate build up, a Bonferroni procedure was used to keep the alpha level at .05 . A $p$-value of $\leq .005$ will be used.

* Correlation is significant at the 0.05 level (2-tailed).

weighted average of 3.2-3.7, included: Interpersonal Communication (53.9\%), Public Evangelism (52.5\%), Personal Spiritual Growth (40.7\%), Special Services (40.3\%), and Personal Evangelism (33.9\%). The pastoral competences that alumni felt they were least prepared for, based on a weighted average of 1.5-1.8, included: Counseling (advanced skills) (81.7\%) and Children's Ministry (70.6\%). 
Table 21

Summary of Regression Analysis for Variables Predicting Ranking of Personal Evangelism $(n=57)$

\begin{tabular}{|c|c|c|c|c|c|}
\hline Variable & $B$ & $S E B$ & $\beta$ & $t$ & Sig. $(p)$ \\
\hline Female & -.16 & .18 & .16 & -.98 & .33 \\
\hline Hispanic/Latino & -.08 & 10 & -.11 & -.75 & .46 \\
\hline African American & .45 & .20 & $.33^{*}$ & 2.28 & $.03 *$ \\
\hline Asian & -.12 & .26 & -.06 & -.44 & .66 \\
\hline Other Ethnicity & -.29 & .37 & -.11 & -.79 & .43 \\
\hline Graduate 2000-2005 & -.21 & .13 & -.27 & -1.60 & .12 \\
\hline Graduated 2006-2010 & -.17 & .13 & -.23 & -1.32 & .19 \\
\hline Attended Seminary Unsponsored & -.23 & .22 & -.15 & -1.03 & .31 \\
\hline Attended Seminary Sponsored & .01 & .10 & .01 & .06 & .95 \\
\hline \multicolumn{6}{|c|}{$\begin{array}{l}\text { Note. Male, White, Non-Hispanic, Graduated } 2011-2014 \text {, No Seminary } \\
\text { Attendance excluded. See coding in Appendix D. To correct for a Type } 1 \text { error } \\
\text { rate build up, a Bonferroni procedure was used to keep the alpha level at .05. A } p \text { - } \\
\text { value of } \leq .005 \text { will be used. }\end{array}$} \\
\hline $\begin{array}{l}* p \leq .05 \\
F=1.16_{(9,57)}, R^{2}=.18\end{array}$ & & & & & \\
\hline
\end{tabular}

\section{Qualitative Results}

In addition to the quantitative data, the survey asked several open-ended questions. The answers from the participants make up the qualitative data of this mixed methods study. The researcher and two research assistants reviewed the qualitative data independently to identify key words, phrases, and ideas that emerged from alumni answers to each question. These were then evaluated and organized into the various 
themes. After clarification and discussion, the agreement on the major themes was unanimous. Two types of categorizations need to be explained: "Miscellaneous" and “n/a." Miscellaneous was used for items that were mentioned two or less times, and n/a was used as a theme when the answers were marked n/a, the responses were not clear enough to identify meaning, or the comments were not related to the courses in this study (see the "note" section under each table below). This section of the chapter will describe the themes that emerged from each of the questions and provide a table and summary of the top answers.

\section{Church Ministry}

Participants were asked the following questions about the Church Ministry course: What was most helpful? What was least helpful? and, What suggestions do you have to improve the class?

\section{Most Helpful}

When analysis was conducted on the responses indicating what was most helpful about the course, several themes surfaced (see Table 22). The top theme was Ministerial Skills $(n=26)$. This can be seen by responses such as "It was helpful just to get a concept of how to do the various activities of the church," "practical ministry scenarios," and "helping to know what to expect when I get into a church." Typical responses included words and phrases such as pastoral ministry, church manual, church activities, church related topics, etc.

Another theme that emerged was Special Services $(n=18)$. Respondents specifically mentioned by name the special services of the church that they learned about 
Table 22

Church Ministry: Most Helpful

\begin{tabular}{ll}
\hline Themes & $n$ \\
\hline Ministerial Skills (board meetings, projects) & 26 \\
Special Services (baptism, funerals, weddings) & 18 \\
Course Material (reading, lectures, PowerPoints) & 15 \\
Field Stories Related by Professors in Lecture & 11 \\
Professor (training, character) & 4 \\
Positive Comments (great course, really helpful) & 3 \\
Topics Miscellaneous (leadership) & 3 \\
N/A to the Course & 3 \\
\hline
\end{tabular}

Note. Topics Miscellaneous was used for items with $\leq 2$ responses.

in the Church Ministry course and would include such wording as communion, baptism, funeral, wedding, baby dedication, etc. This can be seen by comments such as "having the funeral visit, baptism practice, and wedding lectures," "the baptismal practice in pool," "communion service," and "trip to a funeral home helped introduce me to some of the most regular activities of a pastor."

The third top theme for what was most helpful in Church Ministries was Course Material. This theme was identified with words about course PowerPoints, required reading, lectures, and assignments. This can be seen in respondent comments such as "PowerPoints were given to us. I have been able to go back to them and refresh my memory," "study of [church] manual," and "The practicality of this class. Most everything that I learned in this class I still use today." 


\section{Least Helpful}

Participants also shared what was least helpful about the Church Ministry course (see Table 23). Most of the responses fell into "n/a" or some category of "Miscellaneous," meaning that there were two or less of the same theme/thought. The top theme for what was least helpful about the course was related to the reading assignments $(n=5)$. This can be seen by comments such as "I recall that some of the course reading was not very helpful in preparing for ministry," "I was uninspired in Church Ministry. It was probably more reading than the lectures that dried me out a little," and "Some of the reading was not applicable." Responses in this theme included specific mention of class reading, reading not applicable, and the mention of a specific book assigned to the students. A few students $(n=5)$ felt that the course was too short and that more time was needed for the material covered by the two semesters of this course. This was identified by such comments as "too much information given in just two classes," and "it was only a two semester class."

\section{Suggestions for Improvement}

When asked to share suggestions for improving the Church Ministry course, many suggestions were given (see Table 24$)$. The top suggestion $(n=7)$ was that the assignments in this course be tied more directly to the Externship Program so that the two courses could be connected to each other and be more practical. The word "externship" was most used to identify this theme. This can be seen by comments such as "work more closely with the extern pastor," "class more closely tied with externship program," and "have it work together with the externship program so people get more practical experience." 
Table 23

Church Ministry: Least Helpful

Themes $n$

N/A to the Course

Course Lectures: Miscellaneous

$\begin{array}{ll}\text { Topics: Miscellaneous } & 10\end{array}$

$\begin{array}{lr}\text { Miscellaneous } & 8\end{array}$

$\begin{array}{lr}\text { Course Assignments: Miscellaneous } & 6\end{array}$

Course Assignments: Reading 5

Suggestion: Additional Semester of Course 5

Topics: Church Board 4

Professor (negative comments) 3

Theory (too much given) 3

Topics: Conflict Resolution 3

Topics: Leadership 3

Note. Miscellaneous was used for items with $\leq 2$ responses. Topics Miscellaneous was used for topic items with $\leq 2$ responses.

Alumni also shared that there could be more in the course on how to run and conduct church board meetings $(n=6)$. The phrase "church board" was what was more often used to identify this theme. This can be seen by comments such as "hands on running a board meeting," "spend ... more time on ... board meetings," and "teach pastors how to run committees." 
Table 24

Church Ministry: Suggestions

\begin{tabular}{ll}
\hline Themes & $n$ \\
\hline Topics Miscellaneous & 17 \\
N/A to the Course & 7 \\
Externship (tie course to church more closely) & 7 \\
Topics to Add: Church Board & 6 \\
Course Material/Assignments & 5 \\
Topics to Add: Leadership & 5 \\
More Semesters (add additional semester) & 4 \\
Topics to Add: Conflict Resolution & 4 \\
Topics to Add: Counseling & 4 \\
Positive Comments about the Course & 3 \\
Professor Negative Comments & 3 \\
Topics to Add: Church Finance & 3 \\
\hline Note. Topics Miscellaneous was used for course topics with $\leq 2$ responses.
\end{tabular}

\section{Evangelistic Preaching and Public Evangelism}

Participants were asked the following questions about the Evangelistic Preaching and Public Evangelism course: What was most helpful? What was least helpful? and, What suggestions do you have to improve the class?

\section{Most Helpful}

When analysis was conducted on the responses indicating what was most helpful about the Evangelistic Preaching and Public Evangelism course, several themes surfaced 
(see Table 25). The theme with the most comments was about actually doing the evangelistic preaching $(n=23)$. This can be seen by comments such as "preaching so many times was very, very helpful, and had been useful in my ministry since," "opportunities to actually preach," "how to preach evangelistically."

Table 25

Evangelistic Preaching and Public Evangelism: Most Helpful

\begin{tabular}{ll}
\hline Themes & $n$ \\
\hline Preaching (the presenting experience itself) & 23 \\
Hands-On Experience (interaction with churches) & 21 \\
Evangelistic Preaching Course (cycle of evangelism, answers) & 19 \\
Series (how to conduct) & 15 \\
N/A to Course & 4 \\
Mentors (professor feedback) & 3 \\
Positive Comment & 1 \\
\hline
\end{tabular}

A second theme with high response rate was the hands-on or practical nature of the course $(n=21)$. While similar to the theme of evangelistic preaching above, the hands-on theme denotes the practicality of the experience. This can be seen by comments such as "hands on experience preaching a full length public evangelism series," "nothing equals "just do it," and "the actually church work of evangelism."

A third theme indicated in the responses was about the Evangelistic Preaching course, or the classroom side (as opposed to the hands-on field work) of the course. Nineteen answers shared how this was helpful with comments such as "class time where we'd get to ask questions on how to deal with the things we were dealing with during the 
nights," "pushing and getting honest feedback from church members and teachers," and "learning the philosophy of evangelism."

\section{Least Helpful}

The survey answers showed that there were areas of the Evangelistic Preaching and Public Evangelism course that were least helpful (see Table 26). The top three themes, each with five responses, were Sermon Material, Sermon Personalized, and Site Coordinator/Pastor. Alumni felt that the preaching material they were asked to follow was not relevant to today's audiences. This can be seen with comments such as “old outdated methods," "it's outdated," and "evangelistic resources were limited in scope."

Respondents also shared a desire to have been able to personalize or write more of their own sermons rather than just modify the contents of the sermons they were given. This can be seen by comments such as "I wish I had been allowed to write my own sermons," "no time spent on personalizing the presentations," and "we didn't write our own sermons."

There was also dissatisfaction with the site coordinator and/or the local pastor that the students worked with. This can be seen by comments such as "we had an unsupportive local church pastor," "given a church with absentee pastor. No ground work had been done," and "most of class materials from [site coordinator] was outdated and pretty much useless." 
Table 26

Evangelistic Preaching and Public Evangelism: Least Helpful

\begin{tabular}{lc}
\hline Themes & $n$ \\
\hline Course Miscellaneous & 10 \\
N/A to Course & 10 \\
Sermon Material (outdated and not relevant) & 5 \\
Sermon Personalized (not allowed) & 5 \\
Site Coordinator/Pastor (unsupportive or not relevant) & 5 \\
Series Pre and Post Preparation (church no groundwork) & 4 \\
Course Lectures (by presenter not helpful) & 3 \\
Course Unhelpful (outdated sermons) & 3 \\
Positive Comment & 3 \\
Series Location (distance to church, stateside vs. overseas) & 3 \\
\hline
\end{tabular}

Note. Course Miscellaneous used for items with $\leq 2$ responses.

\section{Suggestions for Improvement}

Finally, students were asked to give suggestions for how the Evangelistic Preaching and Public Evangelism component of their education could be made more useful. Several themes arose from the answers given by alumni (see Table 27).

The responses were varied and scattered over a wide range of areas, many with only three or four suggestions that barely made the cut of $>2$ responses. The one suggestion indicated most by the participants $(n=7)$ was the desire for more involvement in both the pre- and post-work for the evangelistic series. The students wished that they could have participated more in helping to prepare the local church for the meetings they preached at, as well as helped with the follow-up work after the meetings ended. This 
Table 27

Evangelistic Preaching and Public Evangelism: Suggestions

\begin{tabular}{ll}
\hline Themes & $n$ \\
\hline N/A to Course & 9 \\
Miscellaneous & 8 \\
Series Pre- and Post-work Needed by Churches/Students & 7 \\
Course Materials (change methodology and reading) & 4 \\
Course More Units/Time added to this Course & 4 \\
Series Location (stateside vs. international) & 4 \\
Series Methods (need more effective/updated methods) & 4 \\
Series More Units/Time added to this Course & 4 \\
Course Materials - Appeals (more training) & 3 \\
Series Should be Tied to Externship & 3 \\
Sermon Material Outdated and Not Relevant Today & 3 \\
Sermon Personalized (should be allowed) & 3
\end{tabular}

Note. Miscellaneous used for items with $\leq 2$ responses.

can be seen by comments such as "spend more time in learning the preparation of the field," "tie it in with the externship program," and "the clerical side of follow up."

\section{The Ministerial Externship Program}

Participants were asked the following questions about the Ministerial Externship

Program: What was most helpful? What was least helpful? and, What suggestions do you have to improve the class? 


\section{Most Helpful}

When analysis was conducted on the responses indicating what was most helpful about the course, several themes surfaced (see Table 28).

Two themes clearly emerged for what alumni thought was the most helpful in the Ministerial Externship Program: experience in real church life $(n=35)$ and the

Table 28

Ministerial Externship Program: Most Helpful

\begin{tabular}{lc}
\hline Themes & $n$ \\
\hline Church Life (participate in local church) & 35 \\
Pastor/Mentor (learning from experienced pastor) & 25 \\
Miscellaneous & 4 \\
N/A to this Course & 3 \\
\hline
\end{tabular}

Note. Miscellaneous used for items with $\leq 2$ responses.

Pastor/Mentor part of the program $(n=25)$. Church life comments included such words and phrases as church life, specific mention of church-related responsibilities and services, and experience. This can be seen by comments such as "working in an actual church environment," "seeing the theoretical become a reality," and "participating in the different activities/ministries of my externship church."

Comments related to their supervision pastor as a mentor, their weekly meetings, and learning from an experienced pastor were indicator words for the positive scores on pastor/mentor. This can be seen by comments such as "one on one mentor-ship with a 
pastor in the field," "I continually recall and put into practice things [the pastor] taught me," and "weekly meetings with your mentor."

\section{Least Helpful}

While the pastor/mentor relationship scored high in what was most helpful about the Ministerial Externship Program, it also received the most comments $(n=15)$ when participants were asked what was least helpful about the program (see Table 29). It seems from the responses that the alumni's feelings about the Externship Program was

Table 29

Ministerial Externship Program: Least Helpful

\begin{tabular}{lc}
\hline Themes & $n$ \\
\hline Pastor/Mentor (ineffective mentoring) & 15 \\
N/A to Course & 9 \\
Positive Comments About the Course & 7 \\
Miscellaneous & 7 \\
Church Readiness (unprepared for externs) & 5 \\
Church Miscellaneous Comments & 4 \\
Course Report/Assignments (need flexibility and relevancy) & 4 \\
Preaching (few opportunities for externs) & 4
\end{tabular}

Note. Church Miscellaneous used for items with $\leq 2$ responses. Miscellaneous used for items with $\leq 2$ responses.

heavily tied to the relationship they had with their supervising pastor. This can be seen by comments such as "[pastor] struggled to find ways to involve me," "I had a weak 
mentorship in one setting," and "my pastor was not a mentor therefore I didn't benefit from him."

Despite being asked what was least helpful, the second highest response $(n=7)$ was in the form of positive comments about the program. This can be seen by comments such as "I loved my church," "everything was helpful," and "this was the single most important part of the program practical for me."

A third theme dealt with the lack of church readiness in the Externship Program. This can be seen by comments such as "the church was not really set up to have a mentee," "the church itself not really giving a variety of opportunities in which to experience ministry," and, because of course requirements to meet, they "did not fit all people or all churches."

\section{Suggestions for Improvements}

In response to being asked for suggestions to improve the program (see Table 30), the pastor/mentor theme again received the most responses $(n=14)$. Student responses to this theme included ideas like pairing up the student with the right pastor/mentor, better communication with the extern pastor, and a need for a high degree of commitment by the mentoring pastor to be involved in the program. This can be seen by comments such as "ask pastor if they truly want to mentor the student," "pair up mentors and externs based on personality and leadership styles," and "more care should be taken in the selection of church and pastors allowed to participate in this program."

Another theme suggested to improve the Externship Program dealt with student participation $(n=6)$. This can be seen by comments such as "allow the extern's [sic] to be part of the preaching rotation," "students should be allowed to participate in ALL 
Table 30

Ministerial Externship Program: Suggestions

\begin{tabular}{ll}
\hline Themes & $n$ \\
\hline Mentoring Experience Needs Improvement & 14 \\
Miscellaneous & 14 \\
N/A to Course & 10 \\
Student Participation in Church Should Increase & 6 \\
Church Pairing Should be More Intentional & 5 \\
Assignment Flexibility Needed for Students & 4 \\
Positive Comments & 3 \\
\hline
\end{tabular}

Note. Miscellaneous used for items with $\leq 2$ responses.

aspects of church function," and "participate in the planning session of different ministries within the church."

\section{Interpersonal Ministry}

Participants were asked the following questions about the Interpersonal Ministry course: What was most helpful? What was least helpful? and, What suggestions do you have to improve the class?

\section{Most Helpful}

When analysis was conducted on the responses indicating what was most helpful about the Interpersonal Ministry course, several themes surfaced (see Table 31). Twentyseven students indicated the communication skills learned during the semester, by comments such as "how to communicate and reach people," "how to listen," and "teach me the fundamentals of communication and basic listening skills." 
Table 31

Interpersonal Ministry: Most Helpful

\begin{tabular}{ll}
\hline Themes & $n$ \\
\hline Communication Skills Learned in Course & 27 \\
Listening Lab (practical application of skills) & 15 \\
Positive Comments about the Course & 13 \\
Professor Effective in Teaching Skills & 8 \\
N/A to Course & 8 \\
Course Content - Miscellaneous & 7 \\
Course Content - Visitation Skills Learned & 3 \\
\hline
\end{tabular}

Note. Course Content - Miscellaneous was used for items with $\leq 2$ responses.

A second major theme was the listening lab during the last half of the semester. Students responded $(n=15)$ very positive to the practical application of what they had learned. Key thoughts for this theme were class visit, lab session, and student interviews. This can be seen by comments such as "active listening session," "role play," and "listening labs were hands down one of the most helpful things I learned in my entire time at Southern."

Positive comments also garnered several responses $(n=13)$. This can be seen by comments such as "one of the top three skills I learned at Southern," "one of the best classes I took at Southern," and "Everything! I loved it all."

\section{Least Helpful}

When asking for responses about what was least helpful about the Interpersonal Ministry course, the survey did not yield many specific items (see Table 32). The most 
Table 32

Interpersonal Ministry: Least Helpful

\begin{tabular}{lc}
\hline Themes & $n$ \\
\hline Positive Comments about the Course & 22 \\
N/A to Course & 9 \\
Course Content - Miscellaneous & 7 \\
Course Content - Assignments Should be Reduced & 3 \\
\hline
\end{tabular}

Note. Course Content - Miscellaneous was used for items with $\leq 2$ responses.

responses to this question were positive comments about the course $(n=22)$. This can be seen by comments such as "most of it was extremely helpful," "the class was so great!" and "one of the most important classes to my ministry."

Another theme for what was least helpful about the Interpersonal Ministry course was the course assignments. This can be seen by comments such as "there are a lot of group projects," "the homework projects," and "book reports and papers."

\section{Suggestions for Improvement}

Suggestions given by respondents to make the Interpersonal Ministry course better were also limited in scope (see Table 33). The largest response to the question was more positive remarks $(n=25)$. This can be seen by comments such as “it's a great class that does everything it needs to do," "by far one of my favorite classes in undergrad," and "I like the practical structure of the class."

At the top of the list of suggestions for improvement the course was a request for more of the class $(n=5)$. This can be seen by comments such as "just more classes like 
Table 33

Interpersonal Ministry: Suggestions

\begin{tabular}{lc}
\hline Themes & $n$ \\
\hline Positive Statements about the Course & 25 \\
Topics to be added - Miscellaneous & 7 \\
More Course Unit/Time Should be Added & 5 \\
N/A to the Course & 5 \\
Topics to be added - Counseling & 4 \\
Topics to be added - Conflict Resolution & 4 \\
Course - Miscellaneous & 3 \\
\hline
\end{tabular}

Note. Course Miscellaneous used for items with $\leq 2$ responses. Topics

Miscellaneous used for items with $\leq 2$ responses.

it," "more! This was the most needed aspect of ministry," and "this class should have two semesters."

\section{Personal Evangelism}

Participants were asked the following questions about the Personal Evangelism course: What was most helpful? What was least helpful? and, What suggestions do you have to improve the class?

\section{Most Helpful}

When analysis was conducted on the responses indicating what was most helpful about the Personal Evangelism course, several themes surfaced (see Table 34). The theme with the most comments was on Bible study skills $(n=31)$. Key indicators for this theme included phrases such as: learned how to give Bible studies, basics for Bible studies, etc. 
Table 34

Personal Evangelism: Most Helpful

\begin{tabular}{lc}
\hline Themes & $n$ \\
\hline Bible Studies (prepared to give) & 31 \\
Course Content Trains to do Personal Evangelism & 16 \\
N/A to this Course & 9 \\
Professor Professional Experience Helpful & 6 \\
Miscellaneous - Professor Negative Comment & 1 \\
\hline
\end{tabular}

Note. Miscellaneous used for items with $\leq 2$ responses.

Alumni indicated that the course had taught them the skill necessary to give personal Bible studies. This can be seen by comments such as "a great introduction to Bible studies," "the required Bible studies got me out into the community," and "taught me how to begin and maintain a Bible study."

The second most mentioned them was course content $(n=16)$. Examples of this theme included good course, techniques to reach people, written material, theory, etc. This can be seen by comments such as "the printed notes in this class were VERY good-a resource I can still use," "techniques to reaching people," and "relating to people on a personal level.”

\section{Least Helpful}

The survey answers revealed several things that alumni thought were least helpful about the Personal Evangelism course (see Table 35). The most comments were related to a theme on course content $(n=27)$. Answers seemed to indicate that alumni felt that the course was not practical enough, material was not current with the times, and did not 
Table 35

Personal Evangelism: Least Helpful

\begin{tabular}{lc}
\hline Themes & $n$ \\
\hline Course Content Redundant and Not Practical & 27 \\
N/A to this Course & 15 \\
Miscellaneous & 6 \\
Course Assignments were Busywork & 3 \\
\hline
\end{tabular}

Note. Church Miscellaneous used for items with $\leq 2$ responses.

look at other forms of evangelism besides Bible studies. This can be seen by responses such as "outdated statistics," "most of the assignments were akin to business," and "redundant."

Another theme dealt with course assignments $(n=3)$. This can be seen by comments such as "the theoretical ideas and busy work," "atypical amount of filler material," and "frequent reading reports."

\section{Suggestions for Improvement}

Finally, students were asked to share suggestions for improving the Personal Evangelism course (see Table 36). There were many varying ideas, but the survey indicated that more hands-on activities in the course would be helpful $(n=7)$. This can be seen by comments such as "more hands on experience," "less lecture and more opportunities to actually give Bible studies," "having role playing sessions," and "how to find Bible study contacts." 
Table 36

Personal Evangelism: Suggestions

\begin{tabular}{lc}
\hline Themes & $n$ \\
\hline Miscellaneous & 12 \\
N/A to Course & 9 \\
More Hands-on Experience & 7 \\
More Mentoring Needed & 5 \\
More New Methods Needed & 5 \\
Eliminate Course Completely & 4 \\
1 semester Only Instead of 2 Semesters & 3 \\
Professor Negative Comments & 3 \\
\hline Note. Miscellaneous used for items with $\leq 2$ responses. &
\end{tabular}

\section{Reasons for Rating the Professional Courses}

Alumni were asked to provide the reasons for their rating of the five professional courses. Because of the open-ended nature of the question, the answers varied greatly. When analysis was conducted on the responses, several themes surfaced (see Table 37). The most frequent responses came under the theme of positive comments made about the professional courses $(n=12)$. This can be seen by comments such as "this practical part was most useful," "in each of these classes/practices I was introduced to a lot of the basics of ministry and learned some of the skills that I use in ministry," "they are the most practical classes that exist in the program."

\section{Externship Program}

Another area that received many comments was that the Externship Program was unsatisfactory to the alumni $(n=10)$. This can be seen by comments such as "my 
Table 37

Reasons for Rating the Professional Courses

Themes n n

General Positive Comments about the Professional Courses 12

$\begin{array}{ll}\text { General Negative Comments about the Professional Courses } & 7\end{array}$

$\begin{array}{lr}\text { Church Ministry Satisfactory (practical course) } & 2\end{array}$

Church Ministry Unsatisfactory (some topics not covered) 6

Evangelistic Preaching and Public Evangelism Satisfactory (practical) 8

Evangelistic Preaching and Public Evangelism Unsatisfactory 7 (methods/materials outdated, training lacking)

$\begin{array}{ll}\text { Externship Program Satisfactory (practical hands on learning) } & 6\end{array}$

$\begin{array}{ll}\text { Externship Program Unsatisfactory } & 10\end{array}$

(poor mentoring, not real church experience)

$\begin{array}{ll}\text { Interpersonal Ministry Satisfactory (useful, practical) } & 7\end{array}$

$\begin{array}{ll}\text { Interpersonal Ministry Unsatisfactory (out of touch) } & 1\end{array}$

$\begin{array}{lr}\text { Personal Evangelism Satisfactory (practical) } & 6\end{array}$

Personal Evangelism Unsatisfactory (redundant, professor, content) 8

N/A to the Professional Courses 12 
externship was not helpful. The pastor was busy," "The externship program was just getting started and worked poorly for me. My coordinating pastor didn't understand the requirements of the program and was often unavailable," and, "My externship wasn't particularly engaging."

\section{Personal Evangelism}

The Personal Evangelism course also received comments indicating some unsatisfactory feelings about this course $(n=8)$. This can be seen by comments such as "Personal Evangelism I was a great class! Personal Evangelism II was a repeat of I and not that good," "Personal Evangelism was rated low because it focused to narrowly on personal Bible Studies," and "Personal Evangelism uses an outdated curriculum, which I did not use in my pastorate."

\section{Evangelistic Preaching and Public Evangelism}

Finally, the Evangelistic Preaching and Public Evangelism course received several satisfactory comments $(n=8)$. This can be seen by comments such as "Field school is intensely practical. It is one of my happiest experiences in my training," "Field school was helpful in learning how to preach evangelistic series," and "the Field School was most helpful because it deepened the friendships of those we were in the program with.”

\section{Senior Exit Interviews}

Each semester graduating theology seniors are invited to complete a survey for the Dean of the SOR regarding the theology program at Southern. Students are asked 
two questions: What was most helpful about your theological training? and, What suggestions would you give to improve the program? Answers that were related to other parts of the program were eliminated from the responses studied.

\section{Most Helpful}

When analysis was conducted on the responses indicating what was most helpful about the total theology program, several themes surfaced (see Table 38). Excellent curriculum was cited as the top theme for what was best about the SOR program $(n=32)$. Words and phrases such as "classes were helpful," "practical," "top-notch," and "good balance between academic and practical" helped to identify this theme. This can be seen by comments such as "applied theology classes - the practical classes that prepare you for what you will actually be doing," “excellent program overall," and "well-rounded program."

Another theme that emerged was the relationship with the professors $(n=30)$. This theme was identified with phrases like "caring professors," "faculty interaction," "friendship with faculty," and "the family aspect of the department." This can be seen in comments such as "teachers interested in answering questions," "professors try to build relationships with students," and, "noticed a desire by teachers to reach out to students." The Interpersonal Ministry course $(n=24)$ was also mentioned in the answer to what was best about theological training at Southern. This theme was identified by the specific mention of the course and the positive comments associated with the course, such as “practical classes: Interpersonal Ministry," "Interpersonal Ministry was a good experience," and "Interpersonal Ministry has been especially good." 
Table 38

Senior Exit Interviews: Most Helpful

\begin{tabular}{|c|c|}
\hline Themes & $n$ \\
\hline Curriculum Excellent & 32 \\
\hline Professor Relationship & 30 \\
\hline Interpersonal Ministry Course & 24 \\
\hline Church Ministry Course & 13 \\
\hline Professors (names) & 12 \\
\hline Professor Quality & 11 \\
\hline Curriculum Practical & 10 \\
\hline Evangelistic Preaching and Public Evangelism Course & 10 \\
\hline Student Fellowship & 10 \\
\hline Externship Church & 8 \\
\hline Classes Spiritual & 7 \\
\hline Faculty Quality and Relationships (Staff) & 7 \\
\hline Ministerial Externship Program & 6 \\
\hline Externship Pastor/Mentor & 6 \\
\hline Student Maturation & 6 \\
\hline Miscellaneous Comments & 6 \\
\hline Curriculum Balanced & 4 \\
\hline Personal Evangelism Course & 4 \\
\hline Positive Experience & 4 \\
\hline Professor Miscellaneous & 4 \\
\hline Job Networking & 3 \\
\hline N/A to Question & 2 \\
\hline
\end{tabular}

Note. Miscellaneous used for items with $\leq 2$ responses. 


\section{Suggestions for Improvement}

When analysis was conducted on the responses indicating what suggestions seniors would give to improve the theology program, several themes surfaced (see Table 39). The theme with the most responses to this open-ended question was to add counseling $(n=26)$ as a course or topic. Alumni felt that this was a deficient part of the program and mentioned this topic specifically. This can be seen by comments such as "expand time to deal with pastoral counseling issues," "offering as electives practical skills in ... pastoral counseling," and "more exposure to counseling."

Suggestions about the Ministerial Externship Program $(n=12)$ were given on what could be improved. Thoughts included for this theme were items like less requirements, more student involvement in local church program, and better involvement by the local pastor. This can be seen by comments such as "extern program can be overwhelming at times in terms of course requirements," "need more clearly defined roles for the student pastors in their extern churches," and "externship could have been enhanced by having a more involved senior pastor."

There were several suggestions $(n=8)$ from alumni that the second semester of Personal Evangelism be dropped. As noted in previous survey comments, students felt that the material covered in the first semester was repeated in the second semester. This can be seen in comments such as "Personal Evangelism could be reduced to one semester," "a lot of duplication between Personal Evangelism I and II," and "second semester of Personal Evangelism was redundant and could be done in the first semester."

Responses also indicated the need for some material on conflict resolution $(n=7)$. This can be seen by comments such as "need more exposure to conflict management," 
Table 39

Senior Exit Interviews: Suggestions to Improve Program

\begin{tabular}{ll}
\hline Themes & $n$ \\
\hline Miscellaneous Comments & 27 \\
Topics to Add - Counseling & 26 \\
Topics to Add - Miscellaneous & 22 \\
N/A to Program & 14 \\
Ministerial Externship Program Miscellaneous & 12 \\
Personal Ministries II Dropped & 8 \\
Topics to Add - Conflict Resolution & 7 \\
Church Ministry Miscellaneous & 7 \\
Topics to Add - Finance & 4 \\
SOR Diversity/Gender & 4 \\
Faculty Student Relationships & 4 \\
Topics to Add - Ethics & 4 \\
Student Mentors & 3 \\
Student Relationships & 3 \\
\hline Note. Miscellaneous used for items with & 7 \\
\hline
\end{tabular}

Note. Miscellaneous used for items with $\leq 2$ responses.

"would be good to have some classes on conflict resolution," and "need more classes on ...conflict resolution.”

\section{Summary}

This mixed methods study examined the perceived effectiveness of the undergraduate theological education for pastoral ministry received at the SOR at Southern. Five professional courses were evaluated in the study: Church Ministry I/II, Externship Program, Evangelistic Preaching and Public Evangelism, Interpersonal 
Ministry, and Personal Evangelism I/II. Correlation for the rating and ranking of the professional courses, linear regression analysis, and Chi-square tests were used to examine the relationship among the variables.

A survey was emailed to 223 alumni who met the inclusion criteria of graduating with a theology degree between May 2000 and December 2014. Seventy-six respondents completed the survey, resulting in a response rate of $34 \%$. Ninety percent of the respondents were male. The ethnic makeup of the sample was 53\% White, NonHispanic, 33\% Hispanic/Latino, 5\% African American, and 2\% other ethnicities. Respondents were evenly spread over the period examined with $32 \%$ graduating during 2000-2005, 28\% during 2006-2010, and 38\% during 2011-2014.

\section{Quantitative Findings}

One of the major findings of this study is the overall level of satisfaction with the theology education received at Southern. Eighty-three percent of the respondents indicated that if they had to do their theology degree over again, they would do it at Southern. Over $80 \%$ felt that their education was "useful" or "really helpful" in preparing them for pastoral ministry.

The study also revealed how alumni rated and ranked the five professional courses. The highest rated course was Interpersonal Ministry with $85 \%$ indicating it was "Very Helpful" or Extremely Helpful." Personal Evangelism was rated the lowest with over half $(62 \%)$ of the respondents indicating that it was either "Not Helpful" or "Somewhat Helpful." The professional courses were also ranked by the alumni from most to least helpful in preparing the graduate for pastoral ministry. The top ranked 
course was Interpersonal Ministry with $33 \%$ of the respondents ranking it highest, and the lowest ranked course was Personal Evangelism (38\%).

One significant finding was the difference in how various ethnic groups rated the Personal Evangelism course. White, Non-Hispanic alumni rated the course significantly lower $(r=-.25, p<.05)$ than other ethnic groups, while Hispanic/Latino rated the course significantly higher $(r=.29, p<.05)$.

\section{Qualitative Findings}

In addition to the quantitative portion of the research, alumni were asked to indicate for each of the five professional courses what was "Most Helpful," "Least Helpful," and "Suggestions for Improvement." The analysis of this data revealed additional insights. Alumni responses indicated that the practical, hands-on nature of the courses was most helpful in their theological education. This was true of the responses for all five of the professional courses.

When asked what was "Least Helpful," alumni responses indicated that the course lectures in the Evangelistic Preaching and Public Evangelism course were perceived to be outdated. They also felt that there was too much redundancy in the second semester of Personal Evangelism that had already been adequately covered in the first semester of the course.

Alumni were asked to share suggestions for how they thought the program could be improved for future students. The answers varied widely. However, two suggestions stood out in their responses. First, alumni felt that it would be helpful to add additional lectures on the topics of basic counseling and conflict resolution. There was also a desire 
to see better mentoring by local pastors and matching of students to churches in the Ministerial Externship Program experience.

Both the qualitative and quantitative questions provided helpful information about the perceived effectiveness of the theological education received by the SOR graduates in preparation for pastoral ministry. This will be discussed in further detail in Chapter 5. 


\section{CHAPTER 5}

\section{CONCLUSIONS, DISCUSSION, AND RECOMMENDATIONS}

If the goal of theological education is to produce effective ministers, how well is Southern meeting this objective? Around the year 2000, several changes were implemented in the theology education program at Southern to provide a greater emphasis on practical experiences such as preaching, giving Bible studies, holding evangelistic meetings, and working in local churches. Since that time, nearly 230 students have graduated from the program. Informal conversations with these alumni about their educational experience has been positive. However, no formal evaluation was conducted to assess the effectiveness of the curricular changes for preparing students for pastoral ministry.

For this reason, an evaluative study was necessary to determine how alumni theology majors who graduated from Southern between the years of 2000 and 2014 felt about their theological education and their perception of how well they were prepared for pastoral ministry. Specifically, the study evaluated the perceived effectiveness of five professional courses (Church Ministry, Evangelistic Preaching and Public Evangelism, the Ministerial Externship Program, Interpersonal Ministry, and Personal Evangelism). 


\section{Methodology}

The research design used for this study was a parallel mixed methods design, same sample (Tashakkori \& Newman, 2010). This design involved collecting a multiplequestion survey with both Likert-style and open-ended questions from the same sample of alumni. In addition, the mixed methods design allowed a comparison of the senior exit interviews to establish whether they are predictors of perceived effectiveness for ministerial job preparedness. The CDC's "Framework for Program Evaluation" was utilized as a guiding framework for the study (CDC, 1999).

The Office of Alumni at Southern provided 223 names that fit the inclusion criteria of graduating from Southern with a Bachelor of Arts in Theology between May 2000 and December 2014. Three emails, a week apart, were sent to each of the alumni encouraging participation in this study. Seventy-six alumni completed the survey (a response rate of $34 \%)$.

\section{Characteristics of Sample}

The participants of the study were made up of 69 males (91\%) and 7 females (9\%). Fifty-three percent identified themselves as White, Non-Hispanic, 33\% Hispanic/Latino, 5\% African American, 5\% Asian, and 2\% marked "Other." The marital status of the respondents was $75 \%$ married and $25 \%$ single.

The responses for date of graduation from Southern were evenly distributed:

$32.9 \%$ during the years $2000-2005 ; 29 \%$ during the years $2006-2010$; and $38.1 \%$ during the years 2011-2014. Forty-six percent had not attended seminary, 6\% attended seminary unsponsored (paid his/her own tuition), and 47\% attended seminary sponsored by an employing conference. One-quarter $(25.3 \%)$ of those who attended seminary did 
so immediately upon graduation from Southern, while $29.3 \%$ of those who attended worked in a pastoral district first.

In response to the question on ministerial employment, the largest group (53.3\%) was those who received a full-time job offer before graduation. Twenty percent did not receive a job offer for pastoral ministry, $17.3 \%$ received a job offer for pastoral ministry within six months of graduation, and $4 \%$ received an offer more than 12 months after graduation. Sixty-three percent are currently pastoring an Adventist church.

\section{Discussion of Findings}

The study findings offer an insight into the perceptions of Southern alumni theology majors graduating between the years of 2000 and 2014 about their theological education and how well they were prepared for pastoral ministry. Overall, $81 \%$ of alumni surveyed indicated that the education they received at Southern equipped them for ministry. When asked if they would repeat their theological education at Southern, $80 \%$ indicated they would do so.

The study also revealed alumni perceptions of the effectiveness of the five professional courses taught in the undergraduate theological program at Southern. Over $60 \%$ of alumni rated four of the professional courses as helpful in preparing them for pastoral ministry. Interpersonal Ministry was rated the highest, with nearly $86 \%$ of alumni labeling it as "Very Helpful" or "Extremely Helpful." Only $43 \%$ of alumni rated Personal Evangelism I \& II as "Very Helpful” or "Extremely Helpful.” Alumni rankings of the professional courses forced respondents to choose which course was the most helpful in preparing them for pastoral ministry. From highest to lowest ranking, the alumni ordered the courses as follows: 


\section{Interpersonal Ministry}

2. Ministerial Externship Program

3. Church Ministry I \& II

4. Evangelistic Preaching and Public Evangelism

5. Personal Evangelism I \& II.

Interestingly, the highest and lowest rated courses corresponded to the highest and lowest ranked courses. Alumni responses to open-ended questions indicated that the reason for higher rating and ranking of Interpersonal Ministry was related to the practical content and the opportunity for students to practice communication skills in a lab setting. The lower rating and ranking of Personal Evangelism I \& II may be explained by qualitative data which revealed that alumni viewed the material in this course as outdated, redundant, and better taught over one semester instead of two.

Alumni survey responses provided rich data for answering the research questions addressed by this study. Following is a discussion of the findings and possible explanations.

1a. Do gender, ethnicity, year of graduation, and seminary attendance individually predict how well each of the five selected courses are rated?

The research indicated that males scored significantly higher when rating Personal Evangelism. The qualitative responses of the female alumni may indicate some of the reasons for their lower scores, such as professor teaching style and feeling that the course should be condensed to one semester. It is important to note when looking at gender, however, that the sample size of females in the study was small $(n=7)$. This is likely a result of historically low enrollment of female students in the theology program at 
Southern. The study findings, therefore, could be deemed inconclusive. This area needs further research.

Additionally, White, Non-Hispanic alumni scored significantly lower than other ethnic groups and Hispanic/Latino alumni scored significantly higher than other ethnic groups when rating Personal Evangelism. One could conjecture that the ethnic variance is related to the Hispanic professor who taught the course, however the qualitative responses do not back that up. Both White, Non-Hispanic and Hispanic/Latino alumni commented that they appreciated the professor's passion for evangelism and felt that the course prepared them to give Bible studies. Both ethnic groups also expressed similar comments for what they found least helpful (redundancy, professor teaching style) and suggestions for change (dated content, condense course to one semester).

There were no other statistical differences noted in the rating of the five professional courses.

1b. Do gender, ethnicity, year of graduation, and seminary attendance individually predict how well each of the five selected courses are ranked?

The results of the correlation for the ranking of the five professional courses showed that African-American alumni scored significantly higher than other ethnic groups for Personal Evangelism. Qualitative responses lend no additional insights into this finding. It is important to note, however, that Southern has historically had low numbers of African American students enrolled in the theology program. Since the sample size of African American alumni in this study $(n=4)$ was too small to generalize, further research is needed in this area. 
There were no other statistical differences noted in the ranking of the five professional courses.

2a. Does gender account for unique variance rating when controlled for ethnicity, year of graduation, and seminary attendance?

The research data reveal that females accounted for a significant amount of unique variance in the rating of Personal Evangelism, rating it lower than males. As noted in question 1a, however, the small sample size of female alumni in this study challenges the generalizability of these findings.

2b. Does ethnicity account for unique variance rating when controlled for gender, year of graduation, and seminary attendance?

The findings indicated that African Americans accounted for a significant amount of unique variance in the rating of Evangelistic Preaching and Public Evangelism, rating it more negatively compared to other ethnicities. An interview with one of the current professors at Southern (personal communication, May 6, 2016) suggests a possible explanation. The professor, who teaches the Evangelistic Preaching and Public Evangelism course, believes that one reason for the lower rating by African-American alumni is that the African-American preaching style is different from the traditional Anglo preaching style. The method of evangelistic preaching taught in the Evangelistic Preaching and Public Evangelism course may not be one that African-American students are familiar or comfortable with, and therefore may not be as useful to them as pastors in the field. 
There were no other statistically significant findings noted in the unique variance rating of courses by other ethnic groups when controlled for gender, year of graduation, and seminary attendance.

2c. Does year of graduation account for unique variance rating when controlled for gender, ethnicity, and seminary attendance?

Those who graduated during 2006-2010 accounted for a significant amount of unique variance in the rating of the Ministerial Externship Program. The students who graduated during 2000-2005 and during 2011-2014 rated the course more positively than those who graduated during 2006-2010. A review of the history of this Externship Program by two current SOR professors (personal communication, December 12, 2016) offers a possible explanation for this variance. The newness of the program may have contributed to the higher ratings by those who graduated during 2000-2005. In addition, around 2010 four new pastors moved into the area, and attracted many theology students who chose to work in their churches as externs. Furthermore, the qualitative responses of students who graduated during 2006-2010 included several negative comments about the pastors they worked with, such as "ask if the pastor truly wants to mentor," "more committed pastors," "better communication between pastor and extern." Further study needs to happen in this area.

2d. Does seminary attendance account for unique variance rating when controlled for gender, ethnicity, and year of graduation?

There were no statistically significant findings noted in the unique variance rating of courses by alumni who did or did not attend seminary, when controlled for gender, ethnicity, and year of graduation. 
3a. Does gender account for unique variance ranking when controlled for ethnicity, year of graduation, and seminary attendance?

There were no statistically significant findings noted in the unique variance ranking of courses by males and females, when controlled for ethnicity, year of graduation, and seminary attendance.

3b. Does ethnicity account for unique variance ranking when controlled for gender, year of graduation, and seminary attendance?

African Americans accounted for a significant amount of unique variance in the ranking of Personal Evangelism, ranking it higher than did other ethnic groups. One should be careful of any generalization, however, because the $n$ was so small. This area needs to be studied further.

There were no statistically significant findings noted in the unique variance ranking of courses by other ethnic groups, when controlled for gender, year of graduation, and seminary attendance.

3c. Does year of graduation account for unique variance ranking when controlled for gender, ethnicity, and seminary attendance?

There were no statistically significant findings noted in the unique variance ranking of courses by alumni based on year of graduation, when controlled for gender, ethnicity, and seminary attendance.

3d. Does seminary attendance account for unique variance ranking when controlled for gender, ethnicity, and year of graduation? 
There were no statistically significant findings noted in the unique variance ranking of courses by alumni who did or did not attend seminary, when controlled for gender, ethnicity, and year of graduation.

4. For each of the five professional ministerial courses studied, which concepts will be most/least helpful for ministerial job preparedness?

The alumni responses to what were least and most helpful in ministerial job preparedness focused on two major areas: (a) course content, and (b) the practical, or hands-on nature, of the courses. This was true in each of the five professional courses for what was most helpful. Responses such as ministerial skills (Church Ministries), preaching the evangelistic meetings (Evangelistic Preaching and Public Evangelism), working with an actual church and pastor (Externship Program), communication skills learned (Interpersonal Ministry), and knowing how to give Bible studies (Personal Evangelism) show this predominant perception of the theological education given at Southern.

Alumni also shared a few items that were not as helpful in their ministerial education. Most had to do with course content and material (Church Ministries and Evangelistic Preaching and Public Evangelism) and with the poor relationship some had with their Externship pastors.

5. For each of the five professional ministerial courses studied, which topics will graduates suggest adding/eliminating, and why?

While most of comments on the theological education received at Southern was positive, alumni did have some suggestions for the education of future theology majors. There was a consensus that students should be taught basic biblical counseling skills and 
some conflict resolution tools for their work in the local churches. They also felt that while Personal Evangelism effectively trained them to give Bible studies, the second semester of the course seemed redundant and should be eliminated.

\section{Does the senior exit interview predict future perceived effectiveness of} professional ministerial courses for ministerial job preparedness?

Senior exit interviews do give some predictive insight into the effectiveness of the theological education at Southern, even though students have yet to fully apply what they have learned in a local church. For example, graduating students often cited the redundancy of the second semester of Personal Evangelism and the need for basic biblical counseling and conflict resolution skills in their education. This echoes some comments made by alumni in the research survey.

\section{Limitations}

One of the first limitations of this study was the use of a convenience sampling method. The alumni who chose to participate may not be representative of the population. It should also be noted that some of the respondents graduating in recent years may still be attending seminary and have not yet had the opportunity to fully apply their theological education to pastoral ministry.

A second limitation of this study concerns the use of an untested survey instrument developed specifically for this study. While this initial survey did help to collect important information, further testing would improve the usability, reliability, and validity of the tool.

A final limitation is the survey response rate. Even though a $34 \%$ response rate is good for alumni participation in a survey, it does not approach the higher response rate 
needed for ideal research. Therefore, conclusions made from the study findings should be corroborated by additional research.

\section{Conclusions}

Consistency in the study data, both quantitative and qualitative, leads to the conclusion that this initial study is good and can provide value for educators of theology students and for the body of literature on theological education. In view of the findings discussed, several additional conclusions can be made.

1. The most important outcome of this research is the data itself. For the first time, Southern has collected quantitative and qualitative data that can be used to drive discussions on the development and evaluation of curricula for theology majors at Southern. Future discussions can be based upon empirical data rather than anecdotal evidence.

2. The SOR at Southern is effectively preparing its theology majors for pastoral ministry through the five professional courses studied in this research. This is validated by the finding that $80 \%$ of the alumni theology majors surveyed indicating that they would repeat their training at Southern.

3. The alumni responses suggested several positive aspects of the current theological educational program, including hands-on, practical components, and courses taught by professors experienced in pastoral ministry. The Interpersonal Ministry practice lab, Evangelistic Preaching experience, and work in the local church through the Ministerial Externship Program are given high marks for effectively preparing students for pastoral ministry. 
4. The research also indicates areas that can be improved to make the theological education at Southern even more effective in preparing students for pastoral ministry. These include condensing Personal Evangelism to one semester, and the addition of lectures or courses on conflict resolution and basic counseling skills.

5. The senior exit interview is an important tool for evaluating graduating students' perspectives about the theological education program and may give some predictive insight into the effectiveness of the theological education at Southern to prepare students for pastoral ministry.

\section{Recommendations}

The findings of this study have implications for the SOR at Southern, curricula developers, and conference administration. In addition, a couple of areas have been identified that could be addressed in further research.

\section{Recommendations for the School of Religion Faculty}

While several recommendations are offered for improving the teaching of the professional courses in the SOR at Southern, it is first important to acknowledge the support of the faculty in the evaluation of the theology education program at Southern. The feedback and recommendations are objective and constructive, with no intention to personally attack any specific professor.

1. The first recommendation is that the SOR consider the best ways to incorporate education on counseling, conflict resolution, and the pastoral role in church boards and committees. One of the clearest findings of this study was the repeated suggestion by alumni to include basic counseling and conflict resolution skills in the curricula for pastoral education. Other feedback given by alumni who participated in the 
study was the need for the Church Ministry courses to include more on boards and committees. Alumni felt that this would help better prepare them for the administrative responsibilities of pastoral ministry.

2. Another recommendation for future discussions on the theological education at Southern is the need to consider the future of the second semester of the Personal Evangelism course. Both alumni and senior exit interviews indicated that, though students were well trained to give Bible studies, the second semester of the course was redundant. This course needs to be modified or consolidated to one semester. This would free up additional credit hours for addressing the topics suggested above.

3. Alumni also indicated that there be an intentional effort on the part of the professors to keep course content relevant and up-to-date with current trends and practices. This was especially true for the Evangelistic Preaching and Public Evangelism course. Professors should regularly evaluate the lecture material and required reading used in the professional courses and align with current best practices.

4. The research indicated that alumni appreciated the balance in their educational program between the professional courses and academic courses, such as biblical languages and Old and New Testament theology. As faculty considers future changes to curricula, it is recommended that they maintain that balance. For example, if the second semester of Personal Evangelism is dropped from the curricula, they might consider replacing it with another practical course, such as biblical counseling, conflict resolution, or health ministry.

5. The findings in this study highlighted the importance of positive studentteacher relationships in the education of theology students. Interaction with students both 
in and out of the classroom enrich the lives and the education of those who are training to be pastors. It is recommended that SOR professors continue to be intentional to develop these relationships with their students.

6. Another recommendation for the SOR is to consider the changing demographics of theology majors at Southern and plan both curricula and future staffing needs based on these demographics. One-third of the alumni respondents identified as Hispanic/Latino. One SOR professor observed in his current classes that the percentage is much higher (personal communication, November 2, 2016). Although not statistically significant, the African American alumni rated the Evangelistic Preaching and Public Evangelism course more negatively than did other ethnicities, and ranked the Personal Evangelism course higher than the other professional courses. In addition, there were survey comments about the need for female faculty. An intentional sensitivity to gender and ethnic makeup of the student body will enable the program to meet both the needs of the students and future employers.

7. Staffing issues for the Ministerial Externship Program and the Evangelist Preaching and Public Evangelism need to be evaluated. A significant number of alumni responses indicated a less than ideal learning experience. This was mostly attributed to pastors not buying into the educational process and/or churches that didn't seem to know what to do with the student pastors. Though students currently self-select their Externship church, there may need to be a screening, training, and evaluation process to determine which pastors and churches will best contribute to the learning process.

8. It is also recommended that each professor use a TOS annually to confirm that content described in course syllabi is adequately covered. This educational evaluation 
tool may help professors see how effectively or clearly material is being presented to, and understood by, current students. This real-time evaluation can help keep content up-todate and determine if certain themes/topics are even necessary in the course.

9. A final recommendation is to make better use of the senior exit interviews. Currently, exit interviews are voluntary, making the sample size for each semester's graduates small. One suggestion is to tie the exit interviews to the second semester of the Church Ministry course and require students to participate as a part of their grade. This incentive would increase participation and provide valuable feedback for ongoing program evaluation and revision. It may also be helpful to enlist the assistance of the research staff at Southern to develop a sound and statistically strong instrument for these exit interviews.

\section{Recommendations for Curriculum Development}

Implications from this study may also be of importance to those who develop curricula for theology students at institutions of higher education.

1. The first recommendation is for hands-on learning experiences. Some of the highest number of remarks on all five of the courses studied pointed to the practical activities that taught skills used by pastors in church ministry settings. Curricula developers should integrate Kolb's Experiential Learning Theory, which is based on a four-stage learning cycle: (1) Concrete Experience, (2) Reflective Observation, (3) Abstract Conceptualization, and (4) Active Experimentation (Kolb, 1984). This could be accomplished by including a variety of hands-on learning experiences, such as roleplaying, field trips, and assignments in local churches. 
2. Another useful aspect identified by alumni was the sharing of pastoral experiences by their professors. A second recommendation for curricula developers is to include personal stories and ministry case studies. The stories and personal illustrations related about the professors' past ministerial experience or the experience of others in ministry are vital to helping students understand that the theory taught in the classroom is applicable to practice in the field.

3. Third, undergraduate programs must be more than seminary preparation programs. Nearly half of the alumni in this study did not go to the seminary immediately upon graduation to pursue a Master of Divinity. Many graduates are placed in local church assignments within a few weeks after college graduation, often with no senior pastor or intentional conference mentorship program to help them transition to their role as pastor. It is imperative that their needs are considered as curricula are developed. While undergraduate theology education programs cannot train future pastors for everything they will face in ministry, there is a need to expose them to a wide variety of pastoral experiences and skills to better prepare those who will delay or never attend seminary.

4. Fourth, to let the NAD Board of Ministerial and Theological Education manage conversations between the various schools of religion and Andrews Theological Seminary to coordinate curriculum, reduce competition and systemize pastoral education in the NAD.

5. Finally, it is recommended to conduct an alumni survey similar to the one used in this research study every three years. Student and alumni feedback are invaluable for curricula development and evaluation. This ongoing research would provide a larger 
database to give stronger statistical evidence to what is working and what could be improved in theology education programs. As mentioned in the recommendations for the SOR faculty, a regular review of course content could help provide additional insight for curricula development. The results of an annual TOS could provide information for course tune ups between alumni surveys to see if what is being published in the course catalog is representative of what is taught by professors or clearly understood by the students.

\section{Recommendations for Adventist Conferences and Unions}

The findings in this research also suggest recommendations that may be helpful to conference administrators who are charged with the hiring and continuing education of pastors.

1. The first recommendation is to review and follow the current NAD policy on ministerial training (NAD, 2015-2016). The guidelines laid out in the working policy indicates a multiple-step educational process that begins with undergraduate education, followed by obtaining a Master of Divinity at the Andrews University Theological Seminary, an internship program in the local conference, and ongoing continuing education. When conferences do not send their pastors to the seminary, it puts an additional strain on the educational programs taught on the undergraduate level to effectively prepare students for pastoral ministry.

2. The second recommendation is to utilize regular ministerial meetings for professional reflection and continuing education. Rather than merely being times for departmental or program promotion, conference administrators may find their regular pastor meetings to be an opportune time to provide education that will benefit the pastors 
in their church districts. Possible topics could include basic counseling workshops and conflict resolution skills.

3. A third recommendation is to evaluate the impact of a growing number of lay pastoral leaders in the churches who have had little or no theological training and cannot take advantage of the union-sponsored Master of Pastoral Ministry program. Their lack of pastoral and theological training may pose personal and theological challenges to effective leadership.

\section{Recommendations for Further Research}

This research study provides an initial data bank of information from alumni about the theological education they received at Southern. It also contributes to the literature on effectiveness of undergraduate theological education. However, it is important to build on this research.

1. The first recommendation for further research is to repeat this study regularly to solicit responses from new alumni and grow the database of responses. This would be beneficial for a more powerful analysis of the data and clarification of findings.

2. Another area for future research may be to interview local conference administrators (presidents and ministerial directors) on their expectations of pastoral readiness. This group is a significant stakeholder in the outcome of theological education because they are the ones who hire pastors and place them in churches within their territory. It may be of interest to see how the administrator's expectations compare with those of alumni who graduated from Southern's SOR.

3. A third area for further research should focus not just on what is being taught in undergraduate theological education, but what should be taught. A relevant question 
to ask is, Does the current education prepare pastors to minister effectively in the NAD in today's changing culture?

4. Finally, it may be helpful to conduct a similar study on the effectiveness of the professional courses in the Pastoral Care program for preparing graduates for their role as chaplains. Though the enrollment rates in this program are small, alumni feedback could help curricula developers better plan and evaluate the courses taught.

\section{Final Thoughts}

It is the mission of the SOR at Southern to "provide professional training that prepares graduates to serve the Seventh-day Adventist Church effectively in ministry; provide an adequate pre-Seminary training in biblical backgrounds, languages, history, theology, and church ministries to meet entrance requirements to the Master of Divinity program offered by Andrews University; and provide instruction and practical experience in church ministries and public evangelism as outlined in the requirements of the Certification for Ministry" (Southern, 2015). Southern's program for preparing student for ministry has been successful. However, to continue this trend, information is needed to meet the ongoing challenge of providing relevant training in a rapidly changing world.

The study has made an important contribution to the effectiveness of the education given to theology majors at Southern. Yet it has only begun to scratch the surface on the topic of effective undergraduate theological education in preparing students for pastoral ministry. As an initial study, this work presents some exciting insights about alumni perceptions of their education. Insights that hopefully will motivate further inquiry. 
APPENDIX A

IRB APPROVALS AND LETTERS 


\section{Andrews University}

April 21, 2015

Barry Tryon

Tel: 610-914-2059

Email: bjtryon@gmail.com

RE: APPLICATION FOR APPROVAL OF RESEARCH INVOLVING HUMAN SUBJECTS IRB Protocol \#:15-083 Application Type: Original Dept.: Leadership

Review Category: Exempt Action Taken: Approved Advisor: Erich Baumgartner Title: Evaluating the perceived effectiveness of five selected professional courses taken by alumni theology majors and how they are related to selective demographics: A mixed method study.

Your IRB application for approval of research involving human subjects entitled: "Evaluating the perceived effectiveness of five selected professional courses taken by alumni theology majors and how they are related to selective demographics: A mixed method study" IRB protocol \# 15-083 has been evaluated and determined Exempt from IRB review. You may now proceed with your research.

Please note that any future changes (see IRB Handbook pages 10-11) made to the study design and/or informed consent form require prior approval from the IRB before such changes can be implemented. Incase you need to make changes please use the attached report form.

While there appears to be no more than minimum risks with your study, should an incidence occur that results in a research-related adverse reaction and/or physical injury, (see IRB Handbook pages 11) this must be reported immediately in writing to the IRB. Any research-related physical injury must also be reported immediately to the University Physician, Dr. Reichert, by calling (269) 473-2222.

We ask that you reference the protocol number in any future correspondence regarding this study for easy retrieval of information.

Best wishes in your research.

Sincerely,

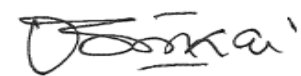

Mordekai Ongo

Research Integrity \& Compliance Officer

Institutional Review Board - 4150 Administration Dr Room 322 - Berrien Springs, MI 49104-0355 Tel: (269) 471-6361 Fax: (269) 471-6543 E-mail: $\underline{\text { irb@andrews.edu }}$ 


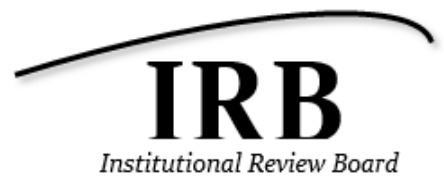

April 16, 2015

Principal Investigator: Barry Tryon

Research Project: Evaluating the perceived effectiveness of five selected professional courses taken by alumni theology majors and how they are related to selective demographics: a mixed method study.

IRB Tracking Number: 2014-2015-092

Dear Barry,

It is a delight to inform you that the Institutional Review Board examined your research study proposal and supporting documents at the IRB committee and has approved your research request as Expedited. We wish you the very best as you move forward with this study and look forward with this study and look forward to reading your findings when they are ready.

If there are minor changes to this research, before making those changes please notify us by completing and submitting FORM B (Certification of Modification, Annual Review, Research Termination, or Research Completion). Please submit applications to irb@southern.edu. If substantial changes are planned you, as the principal investigator, should submit a new IRB FORM A application.

Many blessing to you as you move forward. Please let us know if there is anything else we can do to assist you with this research study.

Always in His service,

\section{Cynthia}

Cynthia Gettys, Ph.D.

IRB Chair

Southern Adventist University

423-236-2285

cgettys@southern.edu

"I applied my mind to study and to explore by wisdom all that is done under the heavens..." - Ecclesiastes 2:13

"Research is to see what everyone else has seen and to think what nobody else has through." - Albert Szent-Gyorgyi 


\section{APPENDIX B}

CONSENT FORM AND SURVEY INSTRUMENT 


\section{CONSENT FORM FOR ONLINE SURVEY}

You are invited to participate in a web-based online survey to evaluate the effectiveness of five professional ministerial courses taken by theology majors at Southern Adventist University for ministerial job preparedness. This is a research project being conducted by Barry Tryon, a PhD student at Andrews University in Berrien Springs, MI. It should take approximately 45 minutes to complete.

PARTICIPATION: Your participation in this survey is voluntary. You may refuse to take part in the research or exit the survey at any time without penalty. You are free to decline to answer any particular question you do not wish to answer for any reason.

BENEFITS: You will receive no direct benefits from participating in this research study. However, your responses may help provide the faculty of the School of Religion at Southern Adventist University with vital information in the evaluation of the practical classes taught to theology majors.

RISKS: There are no foreseeable risks involved in participating in this study other than those encountered in day-to-day life.

CONFIDENTIALITY: Your survey answers will be sent to a link at SurveyMonkey.com where data will be stored in a password protected electronic format. Survey Monkey ${ }^{\circledR}$ does not collect identifying information such as your name, email address, or IP address. Therefore, your responses will remain anonymous. No one will be able to identify you or your answers, and no one will know whether or not you participated in the study.

CONTACT: If you have questions at any time about the study or the procedures, you may contact my research supervisor, Dr. Erich Baumgartner, via phone at 269-471-2523 or via email at baumgart@andrews.edu. Or you may contact Dr. Greg King, Dean of the School of Religion at Southern Adventist University, via phone at 423-236-2976 or via email at gking@ southern.edu. If you feel you have not been treated according to the descriptions in this form, or that your rights as a participant in research have not been honored during the course of this project, or you have any questions, concerns, or complaints that you wish to address to someone other than the investigator, you may contact the Andrews University Institutional Review Board at 269) 471-6361 Fax: (269) 471-6246, or email at irb@andrews.edu.

Thank you for your consideration in being involved in this important research. 
ELECTRONIC CONSENT: Please select your choice below. You may print a copy of this consent form for your records. Clicking on the "Agree" button indicates that:

- You have read the above information

- You voluntarily agree to participate

- You are 18 years of age or older

$\square$ Agree $\quad \square$ Disagree (Participant must answer to access the survey) 


\section{Research Questionnaire}

\section{DEMOGRAPHIC INFORMATION}

1. Gender:

Male

Female

2. Ethnicity

White, Non-Hispanic

Hispanic/Latino

African American

Asian

Other

3. Marital Status

Single

Married

Separated

Divorced

Widowed

4. When did you graduate from Southern with your theology degree?

$2000-2005$

$2006-2010$

$2011-2014$

5. Seminary (Attendance)

Have not attended seminary

Attended seminary (unsponsored)

Attended seminar (sponsored by a conference)

6. Seminary (Time)

Have not attended seminary

Attended Seminary immediately upon graduation

Attended seminary after working in a pastoral district 
7. Sponsorship by a Conference

I did not receive a job offer for pastoral ministry

I received a full time job offer more than 12 months after graduation

I received a full time job offer shortly after graduation (within 6 months)

I received a full time job offer before graduation

Other

8. Grade School Education

I did not attend Adventist elementary school

I attended Adventist elementary school

9. High School Education

I did not attend an Adventist high school

I attended Adventist high school

10. Where was your first conference of hire?

Southern Union

Outside of Southern Union

Please name the conference that first hired you.

11. Are you currently pastoring an Adventist Church?

No

Yes

12. If you had to do it over again, would you still attend Southern Adventist University's School of Religion for your theology degree?

No

Unsure

Yes 


\section{PROFESSIONAL CURRICULUM INFORMATION}

NOTE: This survey is examining the Professional (practices) classes required of theology majors at Southern. In answering these questions please keep in mind that you are not being asked about theological classes, preaching classes, language classes, or general education classes.

13. What is your perception of how your undergraduate training equipped you for your present work as a pastor?

$1=$ The training did not help me at all

$2=\mathrm{A}$ different training would have been more helpful

$3=$ More training would have been helpful

$4=$ Parts of the training were useful and parts were not

$5=$ It has been really useful

Rate the following classes as to how helpful they were in preparing you for pastoral ministry. NOTE: You may use the same number as many times as you would like.

Scale:

$$
\begin{aligned}
& \text { 1=not helpful } \\
& \text { 2=somewhat helpful } \\
& \text { 3=very helpful } \\
& \text { 4=extremely helpful }
\end{aligned}
$$

14. Church Ministry

15. Evangelistic Preaching/Field School

16. Externship Program in local church

17. Interpersonal Ministry

18. Personal Evangelism

$\begin{array}{llll}1 & 2 & 3 & 4 \\ 1 & 2 & 3 & 4 \\ 1 & 2 & 3 & 4 \\ 1 & 2 & 3 & 4 \\ 1 & 2 & 3 & 4\end{array}$

19. Please explain the reasoning for your rating? 
Rank the following classes as to which were the most helpful in preparing you for pastoral ministry. Though all may have been helpful, please rank them in order from most helpful to the least helpful. NOTE: Numbers 1,2,3,4 \& 5 will only be used ONE time for this question.

Scale:

$$
\begin{aligned}
& 1=5^{\text {th }} \text { most helpful } \\
& 2=4^{\text {th }} \text { most helpful } \\
& 3=3^{\text {rd }} \text { most helpful } \\
& 4=2^{\text {nd }} \text { most helpful } \\
& 5=\text { Most helpful }
\end{aligned}
$$

20. Church Ministry

21. Evangelistic Preaching/Field School

22. Externship Program in local church

23. Interpersonal Ministry

24. Personal Evangelism

$\begin{array}{lllll}1 & 2 & 3 & 4 & 5 \\ 1 & 2 & 3 & 4 & 5 \\ 1 & 2 & 3 & 4 & 5 \\ 1 & 2 & 3 & 4 & 5 \\ 1 & 2 & 3 & 4 & 5\end{array}$

25. Please explain the reasoning for your ranking?

\section{PROFESSIONAL/PRACTICAL CLASSES}

The five professional classes being studied in this research are: Church Ministries (1\&2), Personal Evangelism (1\&2), Interpersonal Ministry, Evangelistic Preaching/Field School, and the Externship Program. Please limit your responses to these classes only. Your written responses are important to this survey.

\section{Personal Evangelism}

26. What was most helpful about this class? (written response)

27. What was least helpful about this class (written response)

28. What suggestions do you have concerning this class? (written response)

\section{Church Ministry}

29. What was least helpful about this class (written response)

30. What was most helpful about this class? (written response)

31. What suggestions do you have concerning this class? (written response) 


\section{Interpersonal Ministry}

32. What was least helpful about this class (written response)

33. What was most helpful about this class? (written response)

34. What suggestions do you have concerning this class? (written response)

\section{Evangelistic Preaching/Field School}

35. What was least helpful about this class (written response)

36. What was most helpful about this class? (written response)

37. What suggestions do you have concerning this class? (written response)

\section{Externship Program in a local church}

38. What was least helpful about this class (written response)

39. What was most helpful about this class? (written response)

40. What suggestions do you have concerning this class? (written response)

\section{PASTORAL COMPETENCIES}

How well do you believe the training at Southern equipped you for the following pastoral competencies:

\section{Scale:}

$1=$ Not prepared at all

$2=\mathrm{A}$ little preparation

$3=$ Adequately prepared

$4=$ More than adequately prepared

$5=$ Very prepared

41. Counseling (basic skills)

42. Counseling (advanced skills)

43. Conflict Resolution

44. Public Evangelism

45. Personal Evangelism

46. Leadership Skills

47. Interpersonal Communication Skills

48. Church Management

49. Vision Casting

49. Visitation

$\begin{array}{lllll}1 & 2 & 3 & 4 & 5 \\ 1 & 2 & 3 & 4 & 5 \\ 1 & 2 & 3 & 4 & 5 \\ 1 & 2 & 3 & 4 & 5 \\ 1 & 2 & 3 & 4 & 5 \\ 1 & 2 & 3 & 4 & 5 \\ 1 & 2 & 3 & 4 & 5 \\ 1 & 2 & 3 & 4 & 5 \\ 1 & 2 & 3 & 4 & 5 \\ 1 & 2 & 3 & 4 & 5\end{array}$


50. Church Board

51. Church Finances

52. Small Group Ministry

53. Youth Ministry

54. Children's Ministry

48. Church Growth

49. Discipleship

49. Personal Spiritual Growth

50. Empowering Leadership

51. Worship Services (plan, lead)

45. Special Services (baptism, funeral, etc.)

46. Volunteer Management and Placement

$\begin{array}{lllll}1 & 2 & 3 & 4 & 5 \\ 1 & 2 & 3 & 4 & 5 \\ 1 & 2 & 3 & 4 & 5 \\ 1 & 2 & 3 & 4 & 5 \\ 1 & 2 & 3 & 4 & 5 \\ 1 & 2 & 3 & 4 & 5 \\ 1 & 2 & 3 & 4 & 5 \\ 1 & 2 & 3 & 4 & 5 \\ 1 & 2 & 3 & 4 & 5 \\ 1 & 2 & 3 & 4 & 5 \\ 1 & 2 & 3 & 4 & 5 \\ 1 & 2 & 3 & 4 & 5\end{array}$

Thank you for your time in this important study on pastoral training. 


\section{APPENDIX C}

TABLE OF SPECIFICATIONS 


\section{Table of Specifications}

Respondent (circle one): Professor OR Student

Directions: For each topic, please check ALL the course(s) that you feel cover the topic.

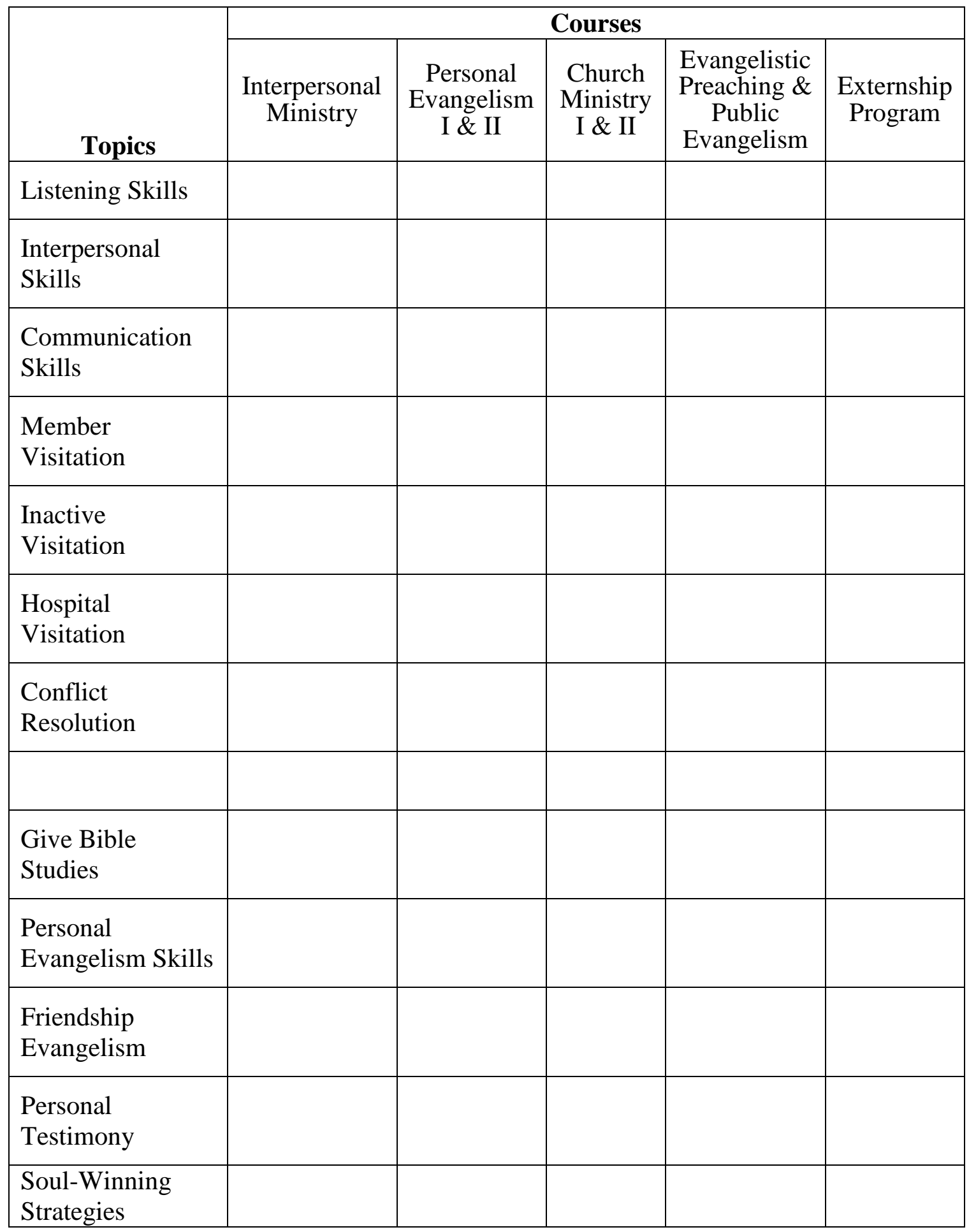




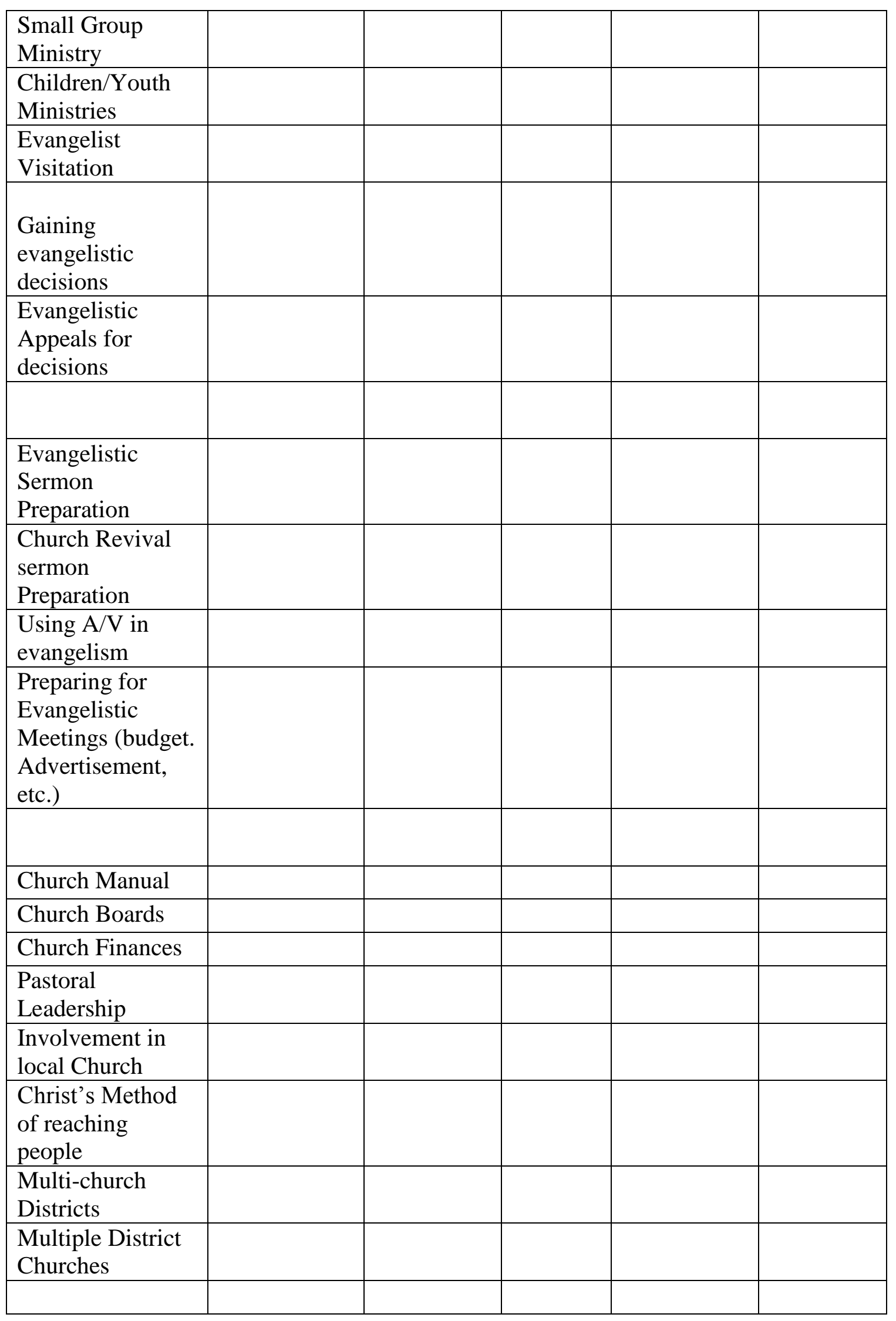




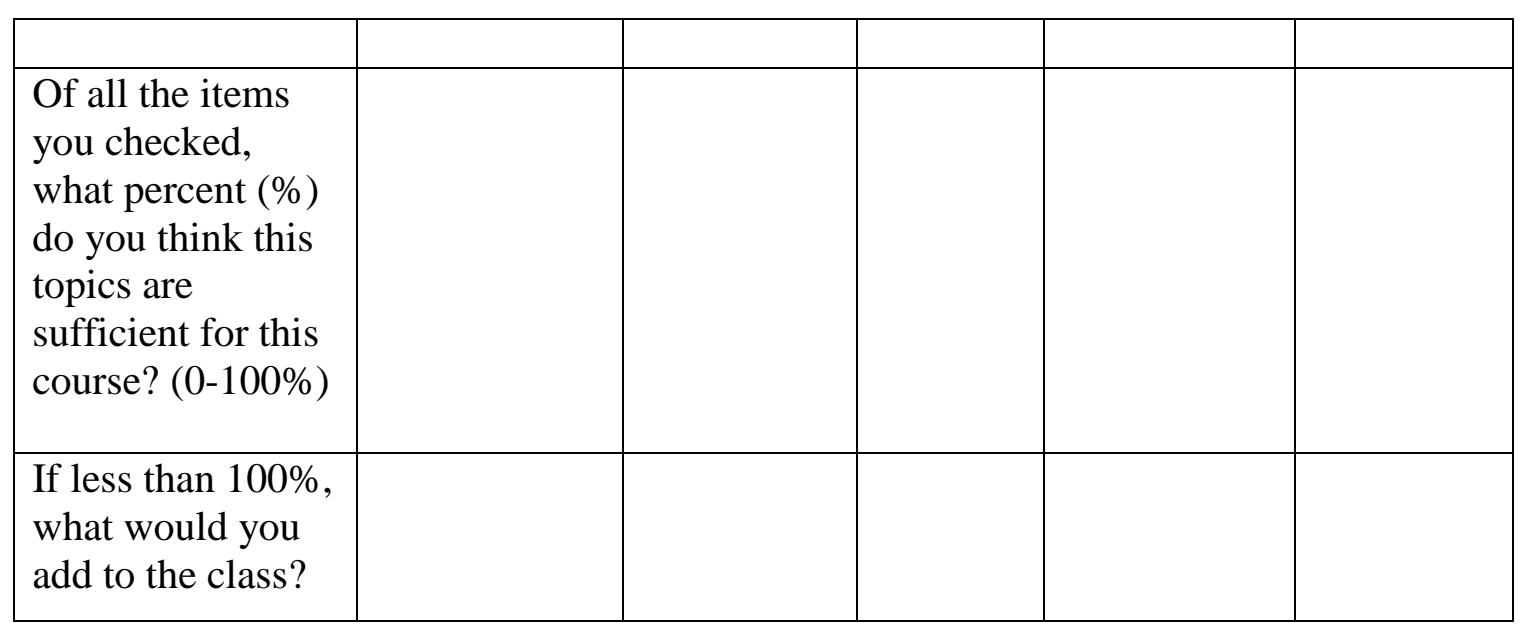

Student Responses for Table of Specifications

\begin{tabular}{|c|c|c|}
\hline Topic & $\begin{array}{c}\text { \# of Student } \\
\text { Responses }\end{array}$ & $\%$ of Agreement \\
\hline \multicolumn{3}{|l|}{ Interpersonal Ministry } \\
\hline Listening Skills & 7 & 58.3 \\
\hline Interpersonal Skills & 6 & 60 \\
\hline Communication Skills & 9 & 75 \\
\hline Member Visitation & 7 & 58.3 \\
\hline Inactive Visitation & 4 & 33.3 \\
\hline Hospital Visitation & 5 & 42.6 \\
\hline Conflict Resolution & 5 & 42.6 \\
\hline \multicolumn{3}{|l|}{ Personal Evangelism } \\
\hline Give Bible Studies & 7 & $58.3 \%$ \\
\hline Personal Evangelism Skills & 8 & $66.7 \%$ \\
\hline Friendship Evangelism & 6 & $50 \%$ \\
\hline Personal Testimony & 5 & $41.7 \%$ \\
\hline Soul-Winning Strategies & 6 & $50 \%$ \\
\hline Small Group Ministry & 6 & $50 \%$ \\
\hline Children/Youth Ministries & 7 & $58.3 \%$ \\
\hline Evangelist Visitation & 5 & $41.7 \%$ \\
\hline Gaining Evangelistic Decisions & 4 & $33.3 \%$ \\
\hline
\end{tabular}




\begin{tabular}{lcc}
\hline Topic & $\begin{array}{c}\text { \# of Student } \\
\text { Responses }\end{array}$ & \% of Agreement \\
\hline Evangelistic Appeals for Decisions & 5 & $41.7 \%$ \\
Evangelistic Cycle & 4 & $33.3 \%$ \\
Spiritual Gifts & 5 & $41.7 \%$ \\
Give Testimony & 6 & $50 \%$ \\
Gospel Presentation & 7 & $58.3 \%$ \\
Biblical Objections & 5 & $41.7 \%$ \\
Appeals for Decisions & 6 & $50 \%$
\end{tabular}

Evangelistic Preaching

Evangelistic Sermon Preparation 4

$33.3 \%$

Church Revival Sermon 3

$33.3 \%$

Preparation

Using $\mathrm{A} / \mathrm{V}$ in Evangelism

3

$33.3 \%$

Preparing for Evangelistic Meetings

4

$33.3 \%$

(Budget. Advertisement, etc.)

Visitation

9

$75 \%$

Meeting Organization

5

$41.7 \%$

Gaining Decisions

3

$33.3 \%$

Evangelism Cycle

5

$41.7 \%$

(Pre-work \& Follow-up)

Preparing People for Baptism

$58.3 \%$

Church Ministry I \& II

Church Manual

6

$50 \%$

Church Boards

8

$66.7 \%$

Church Finances

8

$66.7 \%$

Pastoral Leadership

6

$50 \%$

Involvement in Local Church

9

$75 \%$

Christ's Method of Reaching

$58.3 \%$ 


\begin{tabular}{lcc}
\hline Topic & $\begin{array}{c}\text { \# of Student } \\
\text { Responses }\end{array}$ & \% of Agreement \\
\hline Multi-church Districts & 3 & $25 \%$ \\
Multiple District Churches & 3 & $25 \%$ \\
Church Growth & 6 & $50 \%$ \\
Church Planting & 6 & $50 \%$ \\
Pastoral Counseling & 7 & $58.3 \%$ \\
Membership and Discipline & 6 & $50 \%$ \\
\hline
\end{tabular}

Note: Total number of seniors responding to the survey were $n=12$

$*=$ Falls below the $80 \%$ cut off 


\section{APPENDIX D}

CODED SURVEY INSTRUMENT 


\section{Research Questionnaire}

\section{DEMOGRAPHIC INFORMATION}

1. Gender:

Male

Female

2. Ethnicity

White, Non-Hispanic

Hispanic/Latino

African American

Asian

Other

3. Marital Status

Single

Married

Separated

Divorced

Widowed

4. When did you graduate from Southern with your theology degree?

2000 - 2005

$2006-2010$

$2011-2014$

5. Seminary (Attendance)

Have not attended seminary

Attended seminary (unsponsored)

Attended seminar (sponsored by a conference)

6. Seminary (Time)

Have not attended seminary

Attended Seminary immediately upon graduation

Attended seminary after working in a pastoral district 
7. Sponsorship by a Conference

I did not receive a job offer for pastoral ministry

I received a full time job offer more than 12 months after graduation

I received a full time job offer shortly after graduation (within 6 months)

I received a full time job offer before graduation

Other

8. Grade School Education

I did not attend Adventist elementary school

I attended Adventist elementary school

9. High School Education

I did not attend an Adventist high school

I attended Adventist high school

10. Where was your first conference of hire?

Southern Union

Outside of Southern Union

Please name the conference that first hired you.

11. Are you currently pastoring an Adventist Church?

No

Yes

12. If you had to do it over again, would you still attend Southern Adventist University's School of Religion for your theology degree?

No

Unsure

Yes 


\section{PROFESSIONAL CURRICULUM INFORMATION}

NOTE: This survey is examining the Professional (practices) classes required of theology majors at Southern. In answering these questions please keep in mind that you are not being asked about theological classes, preaching classes, language classes, or general education classes.

13. What is your perception of how your undergraduate training equipped you for your present work as a pastor? -

$1=$ The training did not help me at all

$2=\mathrm{A}$ different training would have been more helpful

$3=$ More training would have been helpful

$4=$ Parts of the training were useful and parts were not

$5=$ It has been really useful

Rate the following classes as to how helpful they were in preparing you for pastoral ministry. NOTE: You may use the same number as many times as you would like.

Scale:

$$
\begin{aligned}
& \text { 1=not helpful } \\
& \text { 2=somewhat helpful } \\
& \text { 3=very helpful } \\
& \text { 4=extremely helpful }
\end{aligned}
$$

14. Church Ministry

15. Evangelistic Preaching/Field School

16. Externship Program in local church

17. Interpersonal Ministry

18. Personal Evangelism

$\begin{array}{llll}1 & 2 & 3 & 4 \\ 1 & 2 & 3 & 4 \\ 1 & 2 & 3 & 4 \\ 1 & 2 & 3 & 4 \\ 1 & 2 & 3 & 4\end{array}$

19. Please explain the reasoning for your rating? 
Rank the following classes as to which were the most helpful in preparing you for pastoral ministry. Though all may have been helpful, please rank them in order from most helpful to the least helpful. NOTE: Numbers 1,2,3,4 \& 5 will only be used ONE time for this question.

Scale:

$$
\begin{aligned}
& 1=5^{\text {th }} \text { most helpful } \\
& 2=4^{\text {th }} \text { most helpful } \\
& 3=3^{\text {rd }} \text { most helpful } \\
& 4=2^{\text {nd }} \text { most helpful } \\
& 5=\text { Most helpful }
\end{aligned}
$$

20. Church Ministry

21. Evangelistic Preaching/Field School

22. Externship Program in local church

23. Interpersonal Ministry

24. Personal Evangelism

$\begin{array}{lllll}1 & 2 & 3 & 4 & 5 \\ 1 & 2 & 3 & 4 & 5 \\ 1 & 2 & 3 & 4 & 5 \\ 1 & 2 & 3 & 4 & 5 \\ 1 & 2 & 3 & 4 & 5\end{array}$

25. Please explain the reasoning for your ranking?

\section{PROFESSIONAL/PRACTICAL CLASSES}

The five professional classes being studied in this research are: Church Ministries (1\&2), Personal Evangelism (1\&2), Interpersonal Ministry, Evangelistic Preaching/Field School, and the Externship Program. Please limit your responses to these classes only. Your written responses are important to this survey.

\section{Personal Evangelism}

26. What was most helpful about this class? (written response)

27. What was least helpful about this class (written response)

28. What suggestions do you have concerning this class? (written response)

\section{Church Ministry}

29. What was least helpful about this class (written response)

30. What was most helpful about this class? (written response)

31. What suggestions do you have concerning this class? (written response) 


\section{Interpersonal Ministry}

32. What was least helpful about this class (written response)

33. What was most helpful about this class? (written response)

34. What suggestions do you have concerning this class? (written response)

\section{Evangelistic Preaching/Field School}

35. What was least helpful about this class (written response)

36. What was most helpful about this class? (written response)

37. What suggestions do you have concerning this class? (written response)

\section{Externship Program in a local church}

38. What was least helpful about this class (written response)

39. What was most helpful about this class? (written response)

40. What suggestions do you have concerning this class? (written response)

\section{PASTORAL COMPETENCIES}

How well do you believe the training at Southern equipped you for the following pastoral competencies:

\section{Scale:}

$1=$ Not prepared at all

$2=\mathrm{A}$ little preparation

$3=$ Adequately prepared

$4=$ More than adequately prepared

$5=$ Very prepared

41. Counseling (basic skills)

42. Counseling (advanced skills)

43. Conflict Resolution

44. Public Evangelism

45. Personal Evangelism

46. Leadership Skills

47. Interpersonal Communication Skills

48. Church Management

49. Vision Casting

49. Visitation

$\begin{array}{lllll}1 & 2 & 3 & 4 & 5 \\ 1 & 2 & 3 & 4 & 5 \\ 1 & 2 & 3 & 4 & 5 \\ 1 & 2 & 3 & 4 & 5 \\ 1 & 2 & 3 & 4 & 5 \\ 1 & 2 & 3 & 4 & 5 \\ 1 & 2 & 3 & 4 & 5 \\ 1 & 2 & 3 & 4 & 5 \\ 1 & 2 & 3 & 4 & 5 \\ 1 & 2 & 3 & 4 & 5\end{array}$


50. Church Board

51. Church Finances

52. Small Group Ministry

53. Youth Ministry

54. Children's Ministry

48. Church Growth

49. Discipleship

49. Personal Spiritual Growth

50. Empowering Leadership

51. Worship Services (plan, lead)

45. Special Services (baptism, funeral, etc.)

46. Volunteer Management and Placement

$\begin{array}{lllll}1 & 2 & 3 & 4 & 5 \\ 1 & 2 & 3 & 4 & 5 \\ 1 & 2 & 3 & 4 & 5 \\ 1 & 2 & 3 & 4 & 5 \\ 1 & 2 & 3 & 4 & 5 \\ 1 & 2 & 3 & 4 & 5 \\ 1 & 2 & 3 & 4 & 5 \\ 1 & 2 & 3 & 4 & 5 \\ 1 & 2 & 3 & 4 & 5 \\ 1 & 2 & 3 & 4 & 5 \\ 1 & 2 & 3 & 4 & 5 \\ 1 & 2 & 3 & 4 & 5\end{array}$

Thank you for your time in this important study on pastoral training. 


\section{APPENDIX E}

ADDITIONAL TABLES NOT PLACED IN PAPER 
Summary of Regression Analysis for Variables Predicting Rating of Church Ministry $(n=68)$

\begin{tabular}{lccccc}
\hline Variable & $B$ & $S E B$ & $\beta$ & $t$ & Sig. $(p)$ \\
\hline Male & .66 & .40 & .24 & 1.66 & .10 \\
Hispanic/Latino & .27 & .22 & .16 & 1.25 & .22 \\
African American & .47 & .45 & .14 & 1.04 & .30 \\
Asian & .07 & .48 & .02 & .15 & .88 \\
Other Ethnicity & .17 & .59 & .04 & .29 & .77 \\
Graduate 2000-2005 & -.33 & .26 & -.20 & -1.27 & .21 \\
Graduated 2006-2010 & -.37 & .26 & -.21 & -1.38 & .17 \\
Attended Seminary Unsponsored & -.30 & .40 & -.10 & -.75 & .46 \\
Attended Seminary Sponsored & -.16 & .22 & -.10 & -.73 & .47 \\
\hline
\end{tabular}

Note. Female, White, Non-Hispanic, Graduated 2011-2014, No Seminary Attendance excluded.

$F=1.10, R^{2}=.14$. 
Summary of Regression Analysis for Variables Predicting Rating of Externship $(n=65)$

\begin{tabular}{lccccc}
\hline Variable & $B$ & $S E B$ & $\beta$ & $t$ & Sig. $(p)$ \\
\hline Female & -.37 & .60 & .09 & -.61 & .54 \\
Hispanic/Latino & .34 & .32 & .14 & 1.07 & .29 \\
African American & -.46 & .79 & -.09 & -.58 & .56 \\
Asian & -.24 & .71 & -.04 & -.34 & .74 \\
Other Ethnicity & 1.30 & .86 & .20 & 1.51 & .14 \\
Graduate 2000-2005 & -.34 & .40 & -.14 & -.85 & .40 \\
Graduated 2006-2010 & -.11 & .39 & -.05 & -.29 & .77 \\
Attended Seminary Unsponsored & -.24 & .66 & -.05 & -.36 & .72 \\
Attended Seminary Sponsored & .06 & .33 & .03 & .18 & .86 \\
\hline
\end{tabular}

Note. Male, White, Non-Hispanic, Graduated 2011-2014, No Seminary Attendance excluded.

$F=.81, R^{2}=.12$. 
Summary of Regression Analysis for Variables Predicting Rating of Interpersonal Ministry $(n=68)$

\begin{tabular}{lccccc}
\hline Variable & $B$ & $S E B$ & $\beta$ & $t$ & Sig. $(p)$ \\
\hline Male & -.08 & .37 & -.03 & -.22 & .83 \\
Hispanic/Latino & .07 & .20 & .04 & .33 & .74 \\
African American & -.33 & .41 & -.11 & -.80 & .43 \\
Asian & -.39 & .45 & -.11 & -.87 & .39 \\
Other Ethnicity & .59 & .54 & .14 & 1.09 & .28 \\
Graduate 2000-2005 & -.24 & .24 & -.16 & -1.00 & .28 \\
Graduated 2006-2010 & -.30 & .24 & -.19 & -1.25 & .22 \\
Attended Seminary Unsponsored & -.53 & .37 & -.19 & -1.42 & .16 \\
Attended Seminary Sponsored & -.04 & .20 & -.03 & -.20 & .84 \\
\hline $\begin{array}{l}\text { Note. Female, White, Non-Hispanic, Graduated 2011-2014, No Seminary Attendance } \\
\text { excluded. } \\
F=.99, R^{2}=13 .\end{array}$
\end{tabular}


Gender and Rating of Church Ministry

\begin{tabular}{lcc}
\hline Variable & $n$ & $\%$ \\
\hline Male & 2 & 3.1 \\
Not helpful & 16 & 25.0 \\
Somewhat helpful & 31 & 48.4 \\
Very helpful & 15 & 23.4 \\
Extremely helpful & & \\
Female & 0 & 0.00 \\
Not helpful & 4 & 66.7 \\
Somewhat helpful & 1 & 16.7 \\
Very helpful & 1 & 16.7 \\
Extremely helpful & & \\
\hline
\end{tabular}

$$
\chi^{2}=4.84, p=.18
$$


Gender and Rating of Evangelistic Preaching and Public Evangelism

\begin{tabular}{lcc}
\hline Variable & $n$ & $\%$ \\
\hline Male & 5 & 8.1 \\
Not helpful & 18 & 29.0 \\
Somewhat helpful & 20 & 32.3 \\
Very helpful & 19 & 30.6 \\
Extremely helpful & & \\
Female & 1 & 16.7 \\
Not helpful & 2 & 33.3 \\
Somewhat helpful & 2 & 33.3 \\
Very helpful & 1 & 16.7 \\
Extremely helpful & & \\
\hline
\end{tabular}

Note. $\chi^{2}=.86, p=.84$ 
Gender and Rating of Ministerial Externship Program

\begin{tabular}{lll}
\hline Variable & $n$ & $\%$ \\
\hline Male & 10 & \\
$\quad$ Not helpful & 13 & 16.4 \\
Somewhat helpful & 14 & 21.3 \\
Very helpful & 24 & 23.0 \\
Extremely helpful & & 39.3 \\
Female & 2 & \\
Not helpful & 2 & 33.3 \\
Somewhat helpful & 1 & 33.3 \\
Very helpful & 1 & 16.7 \\
Extremely helpful & & 16.7 \\
\hline
\end{tabular}

Note. $\chi^{2}=2.08, p=.56$. 
Gender and Rating of Interpersonal Ministry

\begin{tabular}{lcc}
\hline Variable & $n$ & $\%$ \\
\hline Male & 0 & \\
Not helpful & 9 & 0.0 \\
Somewhat helpful & 24 & 14.1 \\
Very helpful & 31 & 37.5 \\
Extremely helpful & & 48.4 \\
Female & 0 & \\
Not helpful & 1 & 0.0 \\
Somewhat helpful & 2 & 16.7 \\
Very helpful & 3 & 33.3 \\
Extremely helpful & & 50.0 \\
\hline
\end{tabular}

Note. $\chi^{2}=.05, p=.97$. 
Gender and Rating of Personal Evangelism

\begin{tabular}{lcc}
\hline Variable & $n$ & $\%$ \\
\hline Male & 5 & 7.9 \\
Not helpful & 28 & 44.4 \\
Somewhat helpful & 16 & 25.4 \\
Very helpful & 14 & 22.2 \\
Extremely helpful & & \\
Female & 3 & 50.0 \\
Not helpful & 3 & 50.0 \\
Somewhat helpful & 0 & 0.0 \\
Very helpful & 0 & 0.0 \\
Extremely helpful & & \\
\hline
\end{tabular}

Note. $\chi^{2}=11.26, p=.01$. 
Ethnicity and Rating of Church Ministry

\begin{tabular}{|c|c|c|}
\hline Variable & $n$ & $\%$ \\
\hline \multicolumn{3}{|l|}{ White } \\
\hline Not helpful & 2 & 5.4 \\
\hline Somewhat helpful & 12 & 32.4 \\
\hline Very Helpful & 16 & 43.2 \\
\hline Extremely helpful & 7 & 18.9 \\
\hline \multicolumn{3}{|l|}{ Hispanic/Latino } \\
\hline Not helpful & 0 & 0.0 \\
\hline Somewhat helpful & 3 & 13.0 \\
\hline Very Helpful & 14 & 60.9 \\
\hline Extremely helpful & 6 & 26.1 \\
\hline \multicolumn{3}{|l|}{ African American } \\
\hline Not helpful & 0 & 0.0 \\
\hline Somewhat helpful & 2 & 50.0 \\
\hline Very Helpful & 0 & 0.0 \\
\hline Extremely helpful & 2 & 50.0 \\
\hline \multicolumn{3}{|l|}{ Asian } \\
\hline Not helpful & 0 & 0.0 \\
\hline Somewhat helpful & 1 & 33.3 \\
\hline Very Helpful & 2 & 67.7 \\
\hline Extremely helpful & 0 & 0.0 \\
\hline \multicolumn{3}{|l|}{ Other } \\
\hline Not helpful & 0 & 0.0 \\
\hline Somewhat helpful & 1 & 33.3 \\
\hline Very Helpful & 2 & 67.7 \\
\hline Extremely helpful & 0 & 0.0 \\
\hline
\end{tabular}

Note. $\chi^{2}=12.04, p=.44$. 
Ethnicity and Rating of Evangelistic Preaching

\begin{tabular}{|c|c|c|}
\hline Variable & $n$ & $\%$ \\
\hline \multicolumn{3}{|l|}{ White } \\
\hline Not helpful & 4 & 11.4 \\
\hline Somewhat helpful & 11 & 31.4 \\
\hline Very Helpful & 9 & 25.7 \\
\hline Extremely helpful & 11 & 31.4 \\
\hline \multicolumn{3}{|l|}{ Hispanic/Latino } \\
\hline Not helpful & 2 & 8.7 \\
\hline Somewhat helpful & 7 & 30.4 \\
\hline Very Helpful & 8 & 34.8 \\
\hline Extremely helpful & 6 & 26.1 \\
\hline \multicolumn{3}{|l|}{ African American } \\
\hline Not helpful & 0 & 0.0 \\
\hline Somewhat helpful & 0 & 33.3 \\
\hline Very Helpful & 2 & 33.3 \\
\hline Extremely helpful & 2 & 33.3 \\
\hline \multicolumn{3}{|l|}{ Asian } \\
\hline Not helpful & 0 & 0.0 \\
\hline Somewhat helpful & 1 & 0.0 \\
\hline Very Helpful & 1 & 100 \\
\hline Extremely helpful & 1 & 0.0 \\
\hline \multicolumn{3}{|l|}{ Other } \\
\hline Not helpful & 0 & 0.0 \\
\hline Somewhat helpful & 0 & 0.0 \\
\hline Very Helpful & 2 & 0.0 \\
\hline Extremely helpful & 0 & 100 \\
\hline
\end{tabular}

Note. $\chi^{2}=7.90, p=.79$. 
Ethnicity and Rating of Ministerial Externship Program

\begin{tabular}{|c|c|c|}
\hline Variable & $n$ & $\%$ \\
\hline \multicolumn{3}{|l|}{ White } \\
\hline Not helpful & 8 & 22.9 \\
\hline Somewhat helpful & 8 & 22.9 \\
\hline Very Helpful & 8 & 22.9 \\
\hline Extremely helpful & 11 & 31.4 \\
\hline \multicolumn{3}{|l|}{ Hispanic/Latino } \\
\hline Not helpful & 2 & 8.7 \\
\hline Somewhat helpful & 5 & 21.7 \\
\hline Very Helpful & 6 & 26.1 \\
\hline Extremely helpful & 10 & 43.5 \\
\hline \multicolumn{3}{|l|}{ African American } \\
\hline Not helpful & 2 & 66.7 \\
\hline Somewhat helpful & 0 & 0.0 \\
\hline Very Helpful & 0 & 0.0 \\
\hline Extremely helpful & 1 & 33.3 \\
\hline \multicolumn{3}{|l|}{ Asian } \\
\hline Not helpful & 0 & 0.0 \\
\hline Somewhat helpful & 2 & 66.7 \\
\hline Very Helpful & 1 & 33.3 \\
\hline Extremely helpful & 0 & 0.0 \\
\hline \multicolumn{3}{|l|}{ Other } \\
\hline Not helpful & 0 & 0.0 \\
\hline Somewhat helpful & 0 & 0.0 \\
\hline Very Helpful & 0 & 0.0 \\
\hline Extremely helpful & 2 & 100.00 \\
\hline
\end{tabular}

Note. $\chi^{2}=15.32, p=.22$. 
Ethnicity and Rating of Interpersonal Ministry

\begin{tabular}{|c|c|c|}
\hline Variable & $n$ & $\%$ \\
\hline \multicolumn{3}{|l|}{ White } \\
\hline Not helpful & 0 & 0.0 \\
\hline Somewhat helpful & 6 & 16.2 \\
\hline Very Helpful & 13 & 35.1 \\
\hline Extremely helpful & 18 & 48.6 \\
\hline \multicolumn{3}{|l|}{ Hispanic/Latino } \\
\hline Not helpful & 0 & 0.0 \\
\hline Somewhat helpful & 3 & 13.0 \\
\hline Very Helpful & 7 & 30.4 \\
\hline Extremely helpful & 13 & 56.5 \\
\hline \multicolumn{3}{|l|}{ African American } \\
\hline Not helpful & 0 & 0.0 \\
\hline Somewhat helpful & 1 & 25.0 \\
\hline Very Helpful & 2 & 50.0 \\
\hline Extremely helpful & 1 & 25.0 \\
\hline \multicolumn{3}{|l|}{ Asian } \\
\hline Not helpful & 0 & 0.0 \\
\hline Somewhat helpful & 0 & 0.0 \\
\hline Very Helpful & 3 & 100.0 \\
\hline Extremely helpful & 0 & 0.0 \\
\hline \multicolumn{3}{|l|}{ Other } \\
\hline Not helpful & 0 & 0.0 \\
\hline Somewhat helpful & 0 & 0.0 \\
\hline Very Helpful & 0 & 0.0 \\
\hline Extremely helpful & 2 & 100.00 \\
\hline
\end{tabular}

Note. $\chi^{2}=8.91, p=.35$ 
Ethnicity and Rating of Personal Evangelism

\begin{tabular}{|c|c|c|}
\hline Variable & $n$ & $\%$ \\
\hline \multicolumn{3}{|l|}{ White } \\
\hline Not helpful & 7 & 19.4 \\
\hline Somewhat helpful & 16 & 44.4 \\
\hline Very Helpful & 8 & 22.2 \\
\hline Extremely helpful & 5 & 13.9 \\
\hline \multicolumn{3}{|l|}{ Hispanic/Latino } \\
\hline Not helpful & 0 & 0.0 \\
\hline Somewhat helpful & 10 & 43.5 \\
\hline Very Helpful & 5 & 21.7 \\
\hline Extremely helpful & 8 & 34.8 \\
\hline \multicolumn{3}{|l|}{ African American } \\
\hline Not helpful & 1 & 25.0 \\
\hline Somewhat helpful & 1 & 25.0 \\
\hline Very Helpful & 1 & 25.0 \\
\hline Extremely helpful & 1 & 25.0 \\
\hline \multicolumn{3}{|l|}{ Asian } \\
\hline Not helpful & 0 & 0.0 \\
\hline Somewhat helpful & 2 & 50.0 \\
\hline Very Helpful & 1 & 50.0 \\
\hline Extremely helpful & 0 & 0.0 \\
\hline \multicolumn{3}{|l|}{ Other } \\
\hline Not helpful & 0 & 0.0 \\
\hline Somewhat helpful & 1 & 50.0 \\
\hline Very Helpful & 1 & 50.0 \\
\hline Extremely helpful & 0 & 0.0 \\
\hline
\end{tabular}

Note. $\chi^{2}=11.27, p=.51$. 
Year of Graduation and Rating of Church Ministries

\begin{tabular}{lcc}
\hline Variable & $n$ & $\%$ \\
\hline $2000-2005$ & 1 & \\
Not helpful & 8 & 3.2 \\
Somewhat helpful & 11 & 33.3 \\
Very helpful & 4 & 45.8 \\
Extremely helpful & & 16.7 \\
$2006-2010$ & 1 & 1.8 \\
Not helpful & 7 & 33.3 \\
Somewhat helpful & 9 & 42.9 \\
Very helpful & 4 & 19.0 \\
Extremely helpful & & \\
$2011-2014$ & & 0.0 \\
Not helpful & 0 & 20.0 \\
Somewhat helpful & 5 & 48.0 \\
Very helpful & 12 & 32.0 \\
Extremely helpful & 8 & \\
\hline
\end{tabular}

Note. $\chi^{2}=3.64, p=.73$ 
Year of Graduation and Rating of Evangelistic Preaching and Public Evangelism

\begin{tabular}{lll}
\hline Variable & $n$ & $\%$ \\
\hline $2000-2005$ & 3 & 12.5 \\
Not helpful & 6 & 25.0 \\
Somewhat helpful & 8 & 33.3 \\
Very helpful & 7 & 29.2 \\
Extremely helpful & & \\
$2006-2010$ & 1 & 4.8 \\
Not helpful & 7 & 33.3 \\
Somewhat helpful & 6 & 28.6 \\
Very helpful & 7 & 33.3 \\
Extremely helpful & & \\
$2011-2014$ & 2 & 3.7 \\
Not helpful & 7 & 34.8 \\
Somewhat helpful & 8 & 26.1 \\
Very helpful & 6 & \\
Extremely helpful & & \\
\hline
\end{tabular}

Note. $\chi^{2}=1.38, p=.97$. 
Year of Graduation and Rating of Interpersonal Ministry

\begin{tabular}{lcc}
\hline Variable & $n$ & $\%$ \\
\hline $2000-2005$ & 0 & 0.0 \\
Not helpful & 4 & 16.7 \\
Somewhat helpful & 10 & 41.7 \\
Very helpful & 10 & 41.7 \\
Extremely helpful & & \\
$2006-2010$ & 0 & 0.0 \\
Not helpful & 5 & 23.8 \\
Somewhat helpful & 7 & 33.3 \\
Very helpful & 9 & 42.9 \\
Extremely helpful & & \\
$2011-2014$ & 15 & 0.0 \\
Not helpful & 0 & 4.0 \\
Somewhat helpful & 1 & 36.0 \\
Very helpful & 9 & 60.0 \\
Extremely helpful & & \\
\hline
\end{tabular}

Note. $\chi^{2}=4.55, p=.34$. 
Year of Graduation and Rating of Personal Evangelism

\begin{tabular}{lcc}
\hline Variable & $n$ & $\%$ \\
\hline $2000-2005$ & 2 & \\
Not helpful & 11 & 4.3 \\
Somewhat helpful & 6 & 45.8 \\
Very helpful & 5 & 25.0 \\
Extremely helpful & & 20.8 \\
$2006-2010$ & 2 & \\
Not helpful & 13 & 9.5 \\
Somewhat helpful & 3 & 61.9 \\
Very helpful & 3 & 14.3 \\
Extremely helpful & & 14.3 \\
$2011-2014$ & 7 & 29.2 \\
Not helpful & 4 & 29.2 \\
Somewhat helpful & 7 & 25.0 \\
Very helpful & 7 & \\
Extremely helpful & 6 & \\
\hline
\end{tabular}

Note. $\chi^{2}=5.27, p=.51$. 
Seminary Attendance and Rating of Church Ministry

\begin{tabular}{lcc}
\hline Variable & $n$ & $\%$ \\
\hline Did not attend & 1 & 3.4 \\
Not helpful & 5 & 17.2 \\
Somewhat helpful & 14 & 48.3 \\
Very helpful & 9 & 31.0 \\
Extremely helpful & & \\
Attended Unsponsored & 0 & 0.0 \\
Not helpful & 3 & 60.0 \\
Somewhat helpful & 1 & 20.0 \\
Very helpful & 1 & 20.0 \\
Extremely helpful & & \\
Attended Sponsored & 17 & 7.8 \\
Not helpful & 12 & 33.3 \\
Somewhat helpful & 17 & 47.2 \\
Very helpful & & 16.7 \\
Extremely helpful & 6 & \\
\hline
\end{tabular}

Note. $\chi^{2}=5.75, p=.45$. 
Seminary Attendance and Rating of Evangelistic Preaching and Public Evangelism

\begin{tabular}{lcc}
\hline Variable & $n$ & $\%$ \\
\hline Did not attend & 2 & 7.4 \\
Not helpful & 10 & 37.0 \\
Somewhat helpful & 11 & 40.7 \\
Very helpful & 4 & 14.8 \\
Extremely helpful & & \\
Attended Unsponsored & 1 & 20.0 \\
Not helpful & 2 & 40.0 \\
Somewhat helpful & 1 & 20.0 \\
Very helpful & 1 & 20.0 \\
Extremely helpful & & \\
Attended Sponsored & 3 & 8.3 \\
Not helpful & 8 & 22.2 \\
Somewhat helpful & 10 & 27.8 \\
Very helpful & 15 & 41.7 \\
Extremely helpful & & \\
\hline
\end{tabular}

Note. $\chi^{2}=7.14, p=.31$. 
Seminary Attendance and Rating of Ministerial Externship Program

\begin{tabular}{lcc}
\hline Variable & $n$ & $\%$ \\
\hline Did not attend & 3 & 10.7 \\
Not helpful & 9 & 32.1 \\
Somewhat helpful & 7 & 25.0 \\
Very helpful & 9 & 32.1 \\
Extremely helpful & & \\
Attended Unsponsored & 2 & 50.0 \\
Not helpful & 0 & 0.0 \\
Somewhat helpful & 1 & 50.0 \\
Very helpful & 1 & 0.0 \\
Extremely helpful & & \\
Attended Sponsored & 7 & 20.0 \\
Not helpful & 7 & 17.1 \\
Somewhat helpful & 6 & 20.0 \\
Very helpful & 7 & 42.9 \\
Extremely helpful & & \\
\hline
\end{tabular}

Note. $\chi^{2}=6.55, p=.37$ 
Seminary Attendance and Rating of Interpersonal Ministry

\begin{tabular}{lcc}
\hline Variable & $n$ & $\%$ \\
\hline Did not attend & 0 & 0.0 \\
Not helpful & 1 & 3.4 \\
Somewhat helpful & 14 & 48.3 \\
Very helpful & 14 & 48.3 \\
Extremely helpful & & \\
Attended Unsponsored & 0 & 0.0 \\
Not helpful & 2 & 40.0 \\
Somewhat helpful & 2 & 40.0 \\
Very helpful & 1 & 20.0 \\
Extremely helpful & & \\
Attended Sponsored & 19 & 0.0 \\
Not helpful & 0 & 19.4 \\
Somewhat helpful & 7 & 27.8 \\
Very helpful & 10 & 52.8 \\
Extremely helpful & 19 & \\
\hline
\end{tabular}

Note. $\chi^{2}=8.17, p=.09$. 
Seminary Attendance and Rating of Personal Evangelism

\begin{tabular}{lcc}
\hline Variable & $n$ & $\%$ \\
\hline Did not attend & 4 & \\
Not helpful & 13 & 14.3 \\
Somewhat helpful & 7 & 46.4 \\
Very helpful & 4 & 25.0 \\
Extremely helpful & & 14.5 \\
Attended Unsponsored & 1 & \\
Not helpful & 2 & 20.0 \\
Somewhat helpful & 1 & 40.0 \\
Very helpful & 1 & 20.0 \\
Extremely helpful & & 20.0 \\
Attended Sponsored & 3 & \\
Not helpful & 16 & 23.2 \\
Somewhat helpful & 8 & 20.3 \\
Very helpful & 9 & \\
Extremely helpful & 3.9 \\
\hline
\end{tabular}

Note. $\chi^{2}=1.82, p=.94$. 
Summary of Regression Analysis for Variables Predicting Ranking of Church Ministry $(n=49)$

\begin{tabular}{lccccc}
\hline Variable & $B$ & $S E B$ & $\beta$ & $t$ & Sig. $(p)$ \\
\hline Female & .42 & .31 & .25 & 1.36 & .18 \\
Hispanic/Latino & .19 & .16 & .18 & 1.15 & .26 \\
African American & -.83 & .58 & -.25 & -1.42 & .16 \\
Asian & -.09 & .30 & -.05 & -.31 & .76 \\
Other Ethnicity & -.05 & .37 & -.02 & -.15 & .88 \\
Graduate 2000-2005 & .29 & .19 & .30 & 1.60 & .12 \\
Graduated 2006-2010 & .19 & .19 & .18 & .99 & .33 \\
Attended Seminary Unsponsored & -.19 & .33 & -.10 & -.57 & .57 \\
Attended Seminary Sponsored & -.17 & .16 & -.17 & -.95 & .35 \\
\hline
\end{tabular}

Note. Male, White, Non-Hispanic, Graduated 2011-2014, No Seminary Attendance excluded.

$F=.82_{(9,49)}, R^{2}=.16$. 
Summary of Regression Analysis for Variables Predicting Ranking of Evangelistic Preaching and Public Evangelism $(n=53)$

\begin{tabular}{lccccc}
\hline Variable & $B$ & $S E B$ & $\beta$ & $t$ & Sig. $(p)$ \\
\hline Female & -.24 & .42 & -.11 & -.56 & .58 \\
White, Non-Hispanic & .19 & .16 & .19 & 1.15 & .26 \\
African American & .37 & .35 & .20 & 1.07 & .29 \\
Asian & .23 & .39 & .09 & .58 & .57 \\
Other Ethnicity & -.37 & .54 & -.10 & -.68 & .50 \\
Graduate 2006-2010 & -.19 & .17 & -.18 & -1.10 & .28 \\
Graduated 2011-2014 & -.07 & .23 & -.07 & -.33 & .75 \\
Attended Seminary Unsponsored & -.00 & .28 & -.00 & -.01 & .99 \\
Attended Seminary Sponsored & .05 & .18 & .05 & .29 & .78 \\
\hline
\end{tabular}

Note. Male, Hispanic/Latino, Graduated 2000-2005, No Seminary Attendance excluded.

$F=.48_{(9,53)}, R^{2}=.09$. 
Summary of Regression Analysis for Variables Predicting Ranking of Ministerial Externship Program $(n=60)$

\begin{tabular}{lccccc}
\hline Variable & $B$ & $S E B$ & $\beta$ & $t$ & Sig. $(p)$ \\
\hline Female & -.05 & .26 & -.03 & -.19 & .85 \\
Hispanic/Latino & .18 & .15 & .18 & 1.24 & .22 \\
African American & .33 & .29 & .17 & 1.14 & .26 \\
Asian & .12 & .39 & .04 & .30 & .77 \\
Other Ethnicity & .01 & .38 & .00 & .01 & .99 \\
Graduate 2000-2005 & -.11 & .17 & -.10 & -.60 & .55 \\
Graduated 2006-2010 & .18 & .18 & .16 & .96 & .34 \\
Attended Seminary Unsponsored & .02 & .29 & .01 & .05 & .96 \\
Attended Seminary Sponsored & .17 & .15 & .17 & 1.13 & .27 \\
\hline
\end{tabular}

Note. Male, White, Non-Hispanic, Graduated 2011-2014, No Seminary Attendance excluded.

$F=.48_{(9,60)}, R^{2}=.12$. 
Summary of Regression Analysis for Variables Predicting Ranking of Interpersonal Ministry $(n=56)$

\begin{tabular}{lccccc}
\hline Variable & $B$ & $S E B$ & $\beta$ & $t$ & Sig. $(p)$ \\
\hline Female & .12 & .23 & $.08^{*}$ & .53 & .00 \\
Hispanic/Latino & 3.66 & .14 & .00 & .00 & 1.00 \\
African American & -.54 & .28 & -.29 & -1.96 & .06 \\
Asian & -.15 & .27 & -.08 & -.55 & .59 \\
Other Ethnicity & .27 & .33 & .12 & .78 & .44 \\
Graduate 2000-2005 & -.10 & .16 & -.12 & -.62 & .54 \\
Graduated 2006-2010 & .04 & .16 & .04 & .22 & .83 \\
Attended Seminary Unsponsored & .12 & .23 & .08 & .54 & .59 \\
Attended Seminary Sponsored & -.03 & .14 & -.03 & -.19 & .85 \\
\hline
\end{tabular}

Note. Male, White, Non-Hispanic, Graduated 2011-2014, No Seminary Attendance excluded.

$F=.63_{(9,56)}, R^{2}=.11, * p \leq .05$. 
Ethnicity and Ranking of Church Ministry

\begin{tabular}{lcc}
\hline Variable & $n$ & $\%$ \\
\hline White, Non-Hispanic & 8 & 21.6 \\
Ranked 1 & 12 & 32.4 \\
Ranked 2 & 7 & 18.9 \\
Ranked 3 & 7 & 18.9 \\
Ranked 4 & 3 & 8.1 \\
Ranked 5 & & \\
Hispanic/Latino & & \\
Ranked 1 & 5 & 20.8 \\
Ranked 2 & 6 & 25.0 \\
Ranked 3 & 10 & 41.7 \\
Ranked 4 & 1 & 4.2 \\
Ranked 5 & 3 & 8.3 \\
\hline$\chi^{2}=.5 .40, p=.25$ & &
\end{tabular}


Ethnicity and Ranking of Evangelistic Preaching and Public Evangelism

\begin{tabular}{lcc}
\hline Variable & $n$ & $\%$ \\
\hline White, Non-Hispanic & 8 & 21.6 \\
Ranked 1 & 4 & 10.8 \\
Ranked 2 & 10 & 27.0 \\
Ranked 3 & 8 & 21.6 \\
Ranked 4 & 7 & 18.9 \\
Ranked 5 & & \\
Hispanic/Latino & & \\
Ranked 1 & 1 & 4.2 \\
Ranked 2 & 4 & 16.7 \\
Ranked 3 & 4 & 16.7 \\
Ranked 4 & 7 & 29.2 \\
Ranked 5 & 8 & 33.3 \\
\hline$\chi^{2}=$ 5.64, $p=.23$ & &
\end{tabular}


Ethnicity and Ranking of Ministerial Externship Program

\begin{tabular}{lcc}
\hline Variable & $n$ & $\%$ \\
\hline White, Non-Hispanic & 7 & 18.9 \\
Ranked 1 & 8 & 21.6 \\
Ranked 2 & 5 & 13.5 \\
Ranked 3 & 3 & 8.1 \\
Ranked 4 & 14 & 37.8 \\
Ranked 5 & & \\
Hispanic/Latino & 7 & 29.2 \\
Ranked 1 & 7 & 29.2 \\
Ranked 2 & 3 & 12.5 \\
Ranked 3 & 2 & 8.3 \\
Ranked 4 & 5 & 20.8 \\
Ranked 5 & & \\
\hline$\chi^{2}=2.37, p=.67$ & &
\end{tabular}


Ethnicity and Ranking of Interpersonal Ministry

\begin{tabular}{lcc}
\hline Variable & $n$ & $\%$ \\
\hline White, Non-Hispanic & 12 & 32.4 \\
Ranked 1 & 11 & 29.7 \\
Ranked 2 & 8 & 21.6 \\
Ranked 3 & 5 & 13.5 \\
Ranked 4 & 1 & 2.7 \\
Ranked 5 & & \\
& & \\
Hispanic/Latino & 11 & 45.8 \\
Ranked 1 & 5 & 20.8 \\
Ranked 2 & 4 & 16.7 \\
Ranked 3 & 4 & 16.7 \\
Ranked 4 & 0 & 0.0 \\
Ranked 5 & & \\
\hline$\chi^{2}=$ 2.06, $p=.72$ & & \\
\hline
\end{tabular}


Ethnicity and Ranking of Personal Evangelism

\begin{tabular}{lcc}
\hline Variable & $n$ & $\%$ \\
\hline White, Non-Hispanic & 2 & 5.4 \\
Ranked 1 & 2 & 5.4 \\
Ranked 2 & 7 & 18.9 \\
Ranked 3 & 14 & 37.8 \\
Ranked 4 & 12 & 32.4 \\
Ranked 5 & & \\
Hispanic/Latino & & \\
Ranked 1 & 0 & 0.0 \\
Ranked 2 & 2 & 8.3 \\
Ranked 3 & 3 & 12.5 \\
Ranked 4 & 10 & 41.7 \\
Ranked 5 & 9 & 37.5 \\
\hline$\chi^{2}=$ 2.02, $p=.73$ & &
\end{tabular}


Year of Graduation and Ranking of Church Ministry

\begin{tabular}{lcc}
\hline Variable & $n$ & $\%$ \\
\hline $2000-2005$ & 3 & 18.8 \\
Ranked Least Helpful & 13 & 81.3 \\
Ranked Most Helpful & & \\
$2006-2010$ & 4 & 33.3 \\
Ranked Least Helpful & 8 & 66.7 \\
Ranked Most Helpful & & \\
2011-2014 & 6 & 37.5 \\
Ranked Least Helpful & 10 & 62.5 \\
Ranked Most Helpful & & \\
\hline
\end{tabular}

$\chi^{2}=1.47, p=.48$ 
Year of Graduation and Ranking of Evangelistic Preaching and Public Evangelism

\begin{tabular}{lcc}
\hline Variable & $n$ & $\%$ \\
\hline $2000-2005$ & 9 & 50.0 \\
Ranked Least Helpful & 9 & 50.0 \\
Ranked Most Helpful & & \\
2006-2010 & 11 & \\
Ranked Least Helpful & 4 & 26.3 \\
Ranked Most Helpful & & \\
2011-2014 & 10 & \\
Ranked Least Helpful & 4 & 71.4 \\
Ranked Most Helpful & & 28.6 \\
\hline
\end{tabular}

$\chi^{2}=2.43, p=.30$ 
Year of Graduation and Ranking of Ministerial Externship Program

\begin{tabular}{lcc}
\hline Variable & $n$ & $\%$ \\
\hline $2000-2005$ & 10 & 58.8 \\
Ranked Least Helpful & 7 & 41.2 \\
Ranked Most Helpful & & \\
$2006-2010$ & 4 & 23.5 \\
Ranked Least Helpful & 13 & 76.5 \\
Ranked Most Helpful & & \\
& & \\
$2011-2014$ & 27 & 48.0 \\
Ranked Least Helpful & 35 & 52.0 \\
Ranked Most Helpful & &
\end{tabular}


Year of Graduation and Ranking of Interpersonal Ministry

\begin{tabular}{lcc}
\hline Variable & $n$ & $\%$ \\
\hline $2000-2005$ & 5 & 29.4 \\
Ranked Least Helpful & 12 & 70.6 \\
Ranked Most Helpful & & \\
$2006-2010$ & 2 & 15.4 \\
Ranked Least Helpful & 11 & 84.6 \\
Ranked Most Helpful & & \\
2011-2014 & 3 & 15.8 \\
Ranked Least Helpful & 16 & 84.2 \\
Ranked Most Helpful & & \\
\hline
\end{tabular}

$\chi^{2}=1.3, p=.52$ 
Year of Graduation and Ranking of Personal Evangelism

\begin{tabular}{lcc}
\hline Variable & $n$ & $\%$ \\
\hline $2000-2005$ & 15 & 93.8 \\
Ranked Least Helpful & 1 & 6.3 \\
Ranked Most Helpful & & \\
2006-2010 & 16 & \\
Ranked Least Helpful & 1 & 54.1 \\
Ranked Most Helpful & & \\
2011-2014 & 14 & \\
Ranked Least Helpful & 4 & 22.2 \\
Ranked Most Helpful & & \\
\hline
\end{tabular}

$\chi^{2}=2.93, p=.23$ 
Seminary Attendance and Ranking of Church Ministry

\begin{tabular}{lcc}
\hline Variable & $n$ & $\%$ \\
\hline Did not attend & 5 & 27.8 \\
Ranked Least Helpful & 13 & 72.2 \\
Ranked Most Helpful & & \\
Attended Unsponsored & 1 & 33.3 \\
Ranked Least Helpful & 2 & 66.7 \\
Ranked Most Helpful & & \\
Attended Sponsored & 7 & 30.4 \\
Ranked Least Helpful & 16 & 69.6 \\
Ranked Most Helpful & & \\
\hline
\end{tabular}

$\chi^{2}=.06, p=.97$ 
Seminary Attendance and Ranking of Evangelistic Preaching and Public Evangelism

\begin{tabular}{lcc}
\hline Variable & $n$ & $\%$ \\
\hline Did not attend & 13 & 68.4 \\
Ranked Least Helpful & 6 & 31.6 \\
Ranked Most Helpful & & \\
Attended Unsponsored & 3 & 75.0 \\
Ranked Least Helpful & 1 & 25.0 \\
Ranked Most Helpful & & \\
Attended Sponsored & 14 & \\
Ranked Least Helpful & 10 & 58.3 \\
Ranked Most Helpful & & 41.7 \\
\hline
\end{tabular}

$$
\chi^{2}=.70, p=.70
$$


Seminary Attendance and Ranking of Ministerial Externship Program

\begin{tabular}{lcc}
\hline Variable & $n$ & $\%$ \\
\hline Did not attend & 12 & 50.0 \\
Ranked Least Helpful & 12 & 50.0 \\
Ranked Most Helpful & & \\
Attended Unsponsored & 2 & 66.7 \\
Ranked Least Helpful & 1 & 33.3 \\
Ranked Most Helpful & & \\
& & \\
Attended Sponsored & 10 & 38.5 \\
Ranked Least Helpful & 16 & 61.5 \\
Ranked Most Helpful & & \\
\hline
\end{tabular}

$\chi^{2}=1.26, p=.53$ 
Seminary Attendance and Ranking of Interpersonal Ministry

\begin{tabular}{lcc}
\hline Variable & $n$ & $\%$ \\
\hline Did not attend & 5 & 22.2 \\
Ranked Least Helpful & 19 & 77.8 \\
Ranked Most Helpful & & \\
Attended Unsponsored & 0 & 0.0 \\
Ranked Least Helpful & 4 & 100.0 \\
Ranked Most Helpful & & \\
Attended Sponsored & 5 & 23.8 \\
Ranked Least Helpful & 16 & 76.2 \\
Ranked Most Helpful & 5 & \\
\hline
\end{tabular}

$\chi^{2}=1.18, p=.56$ 
Seminary Attendance and Ranking of Personal Evangelism

\begin{tabular}{lcc}
\hline Variable & $n$ & $\%$ \\
\hline Did not attend & 19 & 82.6 \\
Ranked Least Helpful & 4 & 17.4 \\
Ranked Most Helpful & & \\
Attended Unsponsored & 2 & 100 \\
Ranked Least Helpful & 0 & 0.0 \\
Ranked Most Helpful & & \\
Attended Sponsored & 24 & \\
Ranked Least Helpful & 2 & 7.7 \\
Ranked Most Helpful & & \\
\hline
\end{tabular}

$$
\chi^{2}=.1 .38, p=.50
$$




\begin{tabular}{|c|c|c|}
\hline Variable & $n$ & $\%$ \\
\hline \multicolumn{3}{|l|}{ Counseling (basic skills) } \\
\hline Not prepared at all & 11 & 18.3 \\
\hline A little preparation & 26 & 43.3 \\
\hline Adequately prepared & 11 & 18.3 \\
\hline More than adequately prepared & 5 & 8.3 \\
\hline Very prepared & 7 & 11.67 \\
\hline \multicolumn{3}{|l|}{ Counseling (advanced skills) } \\
\hline Not prepared at all & 34 & 56.7 \\
\hline A little preparation & 15 & 25.0 \\
\hline Adequately prepared & 5 & 8.3 \\
\hline More than adequately prepared & 3 & 5.0 \\
\hline Very prepared & 3 & 5.0 \\
\hline \multicolumn{3}{|l|}{ Conflict Resolution } \\
\hline Not prepared at all & 12 & 20.3 \\
\hline A little preparation & 23 & 39.0 \\
\hline Adequately prepared & 14 & 23.7 \\
\hline More than adequately prepared & 6 & 10.2 \\
\hline Very prepared & 4 & 6.8 \\
\hline \multicolumn{3}{|l|}{ Public Evangelism } \\
\hline Not prepared at all & 0 & 0 \\
\hline A little preparation & 11 & 18.6 \\
\hline Adequately prepared & 17 & 28.8 \\
\hline More than adequately prepared & 17 & 28.8 \\
\hline Very prepared & 14 & 23.7 \\
\hline \multicolumn{3}{|l|}{ Personal Evangelism } \\
\hline Not prepared at all & 1 & 1.7 \\
\hline A little preparation & 14 & 23.7 \\
\hline Adequately prepared & 24 & 40.7 \\
\hline More than adequately prepared & 11 & 18.6 \\
\hline Very prepared & 9 & 15.3 \\
\hline \multicolumn{3}{|l|}{ Leadership Skills } \\
\hline Not prepared at all & 5 & 8.5 \\
\hline A little preparation & 16 & 27.1 \\
\hline Adequately prepared & 21 & 35.6 \\
\hline More than adequately prepared & 12 & 20.3 \\
\hline Very prepared & 5 & 8.5 \\
\hline \multicolumn{3}{|l|}{ Interpersonal Communication Skills } \\
\hline Not prepared at all & 1 & 1.7 \\
\hline A little preparation & 3 & 5.1 \\
\hline
\end{tabular}




\begin{tabular}{|c|c|c|}
\hline Variable & $n$ & $\%$ \\
\hline Adequately prepared & 22 & 37.3 \\
\hline More than adequately prepared & 20 & 33.9 \\
\hline Very prepared & 13 & 20.0 \\
\hline \multicolumn{3}{|l|}{ Church Management } \\
\hline Not prepared at all & 6 & 10.2 \\
\hline A little preparation & 20 & 33.9 \\
\hline Adequately prepared & 14 & 23.7 \\
\hline More than adequately prepared & 14 & 23.7 \\
\hline Very prepared & 5 & 8.5 \\
\hline \multicolumn{3}{|l|}{ Vision Casting } \\
\hline Not prepared at all & & \\
\hline A little preparation & 13 & 21.7 \\
\hline Adequately prepared & 26 & 43.3 \\
\hline More than adequately prepared & 13 & 21.7 \\
\hline Very prepared & 5 & 8.3 \\
\hline \multicolumn{3}{|l|}{ Visitation } \\
\hline Not prepared at all & 1 & 1.7 \\
\hline A little preparation & 17 & 28.3 \\
\hline Adequately prepared & 25 & 41.7 \\
\hline More than adequately prepared & 11 & 18.3 \\
\hline Very prepared & 6 & 10.0 \\
\hline \multicolumn{3}{|l|}{ Church Board } \\
\hline Not prepared at all & 8 & 13.6 \\
\hline A little preparation & 18 & 30.5 \\
\hline Adequately prepared & 19 & 32.2 \\
\hline More than adequately prepared & 11 & 18.6 \\
\hline Very prepared & 3 & 5.1 \\
\hline \multicolumn{3}{|l|}{ Church Finances } \\
\hline Not prepared at all & 15 & 25.4 \\
\hline A little preparation & 26 & 44.1 \\
\hline Adequately prepared & 10 & 17.0 \\
\hline More than adequately prepared & 8 & 13.6 \\
\hline Very prepared & 0 & 0.0 \\
\hline \multicolumn{3}{|l|}{ Small Group Ministry } \\
\hline Not prepared at all & 8 & 13.3 \\
\hline A little preparation & 21 & 35.0 \\
\hline Adequately prepared & 17 & 28.3 \\
\hline More than adequately prepared & 11 & 18.3 \\
\hline Very prepared & 3 & 5.0 \\
\hline \multicolumn{3}{|l|}{ Youth Ministry } \\
\hline Not prepared at all & 18 & 30.5 \\
\hline
\end{tabular}




\begin{tabular}{|c|c|c|}
\hline Variable & $n$ & $\%$ \\
\hline A little preparation & 22 & 37.3 \\
\hline Adequately prepared & 12 & 20.3 \\
\hline More than adequately prepared & 5 & 8.5 \\
\hline Very prepared & 2 & 3.4 \\
\hline \multicolumn{3}{|l|}{ Children's Ministry } \\
\hline Not prepared at all & 24 & 40.7 \\
\hline A little preparation & 20 & 34.0 \\
\hline Adequately prepared & 10 & 17.0 \\
\hline More than adequately prepared & 4 & 6.8 \\
\hline Very prepared & 1 & 1.7 \\
\hline \multicolumn{3}{|l|}{ Church Growth } \\
\hline Not prepared at all & 7 & 12.1 \\
\hline A little preparation & 19 & 32.8 \\
\hline Adequately prepared & 21 & 35.2 \\
\hline More than adequately prepared & 11 & 19.0 \\
\hline Very prepared & 0 & 0 \\
\hline \multicolumn{3}{|l|}{ Discipleship } \\
\hline Not prepared at all & 10 & 17.0 \\
\hline A little preparation & 20 & 33.9 \\
\hline Adequately prepared & 18 & 30.5 \\
\hline More than adequately prepared & 9 & 15.3 \\
\hline Very prepared & 2 & 3.4 \\
\hline \multicolumn{3}{|l|}{ Personal Spiritual Growth } \\
\hline Not prepared at all & 3 & 5.1 \\
\hline A little preparation & 10 & 17.0 \\
\hline Adequately prepared & 22 & 37.3 \\
\hline More than adequately prepared & 13 & 22.0 \\
\hline Very prepared & 11 & 18.6 \\
\hline \multicolumn{3}{|l|}{ Empowering Leadership } \\
\hline Not prepared at all & 8 & 13.6 \\
\hline A little preparation & 16 & 27.1 \\
\hline Adequately prepared & 23 & 39.0 \\
\hline More than adequately prepared & 7 & 11.9 \\
\hline Very prepared & 5 & 8.5 \\
\hline \multicolumn{3}{|l|}{ Worship Services (plan/lead) } \\
\hline Not prepared at all & 6 & 10.0 \\
\hline A little preparation & 13 & 21.7 \\
\hline Adequately prepared & 20 & 33.3 \\
\hline More than adequately prepared & 15 & 25.0 \\
\hline Very prepared & 6 & 10.0 \\
\hline
\end{tabular}




\begin{tabular}{lcc}
\hline Variable & $n$ & $\%$ \\
\hline Not prepared at all & 2 & 3.5 \\
A little preparation & 10 & 17.5 \\
Adequately prepared & 22 & 38.6 \\
More than adequately prepared & 15 & 26.3 \\
Very prepared & 8 & 14.0 \\
Volunteer Management/Placement & & \\
Not prepared at all & 16 & 27.1 \\
A little preparation & 25 & 42.4 \\
Adequately prepared & 9 & 15.3 \\
More than adequately prepared & 7 & 11.9 \\
Very prepared & 2 & 3.4 \\
\hline
\end{tabular}




\section{REFERENCE LIST}

Abel, J. R., \& Deitz, R. (2014). Do the benefits of college still outweigh the costs? Current Issues in Economics and Finance, 20(3), 1-11. Retrieved from www.newyorkfed.org

Agar, F. A. (1926). The local church: It's present and future. New York, NY: Fleming H. Revell.

Atrostic, B. K., Bates, N., Burt, G., \& Silberstein, A. (2001). Nonresponse in U.S. government household surveys: Consistent measure, recent trends, and new insights. Journal of Official Statistics, 17(2), 209-226.

Barna, G. (1993). Today's pastor: A revealing look about what pastors are saying about themselves, their peers and the pressures they face. Ventura, CA: Regal Books.

Bentley University. (January 29, 2014). The Prepared U Project: An in-depth look at millennial preparedness for today's workforce [White paper]. Retrieved from www.bentley.edu/preparedu

Burnsed, B. (November 2, 2010). Online universities: Government cracks down on forprofit schools. US News and World Report. Retrieved from www.usnews.com.

Cannell, L. (2006). Theological education matters: Leadership education for the church. Newbergh, IN: Edcot Press.

Centers for Disease Control and Prevention (CDC). (1999). Framework for program evaluation in public health (RR-11). Retrieved from http://bit.ly/1dcNUOv

Childs, S. L. (2011). A mixed method evaluation of the first fifteen years of the master of divinity with international church planting degree at Southeastern Baptist Theological Seminary (Doctoral dissertation). Available from ProQuest Dissertations \& Theses. (UMI No. 3497128).

Christine, D. W. (2010). Baptist pastoral leadership: An analysis for curriculum development (Doctoral dissertation). Available from ProQuest Dissertations \& Theses. (UMI No. 3436519).

Chronicle of Higher Education and American Public Media's Marketplace [Chronicle]. (2012). The Role of Higher Education in Career Development: Employer Perceptions (White paper). Retrieved from http://bit.ly/1m3YDgj 
Cohen, J., \& Cohen, J. (2003). Applied multiple regression/correlation analysis for the behavioral sciences. Mahwah, NJ: L. Erlbaum Associates.

Corrigan, M. (2011). Ask the alumni: The results of a national alumni survey. American Council on Education, Winter 2011. Retrieved from www.acenet.edu.

Creswell, J. W. (2012). Educational research: Planning, conducting, and evaluating quantitative and qualitative research $\left(4^{\text {th }} \mathrm{ed}\right.$.). Boston, MA: Pearson.

Curran, D., Xu, X., Dewald, S., Johnson, T. R. B., \& Reynolds, R. K. (2012). An alumni survey as a needs assessment for curriculum improvement in obstetrics and gynecology. Journal of Graduate Medical Education, 4(3), 317-321. doi:10.4300/JGME-D-11-00122.1

Doherty, M. (1994). Probability versus non-probability sampling in sample surveys. The New Zealand Statistics Review, March Issue, 21-28. Retrieved from http://www.nss.gov.au

Donaldson, S. I., \& Lipsey, M. W. (2006). Roles for theory in contemporary evaluation practice. In I. Shaw, J. Greene, \& M. Mark (Eds.), The SAGE handbook of evaluation. London, England: SAGE.

Ellington, K. T. (2004). Strategic church/seminary partnerships: An emerging paradigm of contextually-based theological education (Doctoral dissertation). Available from ProQuest Dissertations \& Theses. (UMI No. 3138652).

Escobar, M. (2008). Gauging alumni perceptions of the effectiveness of the masters of public administration (MPA) program at Texas State University-San Marcos in meeting its mission: A follow-up study (Doctoral dissertation). Available from Texas State University.

Fisher, B. G. (2010). The contribution of the college ministry internship program at Grace Bible Church in College Station, Texas to the former interns' discernment and development of ministerial calling (Doctoral dissertation). Available from Dallas Theological Seminary.

Fives, H., \& DiDonato-Barnes, N. (2013). Classroom test construction: The power of a table of specifications. Practical Assessment, Research \& Evaluation, 18(3). Retrieved from http://pareonline.net

Foster, C. R., Dahill, L. E., Golemon, L. A., \& Tolentino, B. W. (2006). Educating clergy: Teaching practices and pastoral imagination. San Francisco, CA: JosseyBass 
Gallup. (2014, February 25). What America needs to know about higher education redesign: The 2013 Lumina study of the American public's opinion on higher education and U.S. business leaders poll on higher education. No increase in proportion of first-time voters [Graphs]. Retrieved from http://bit.ly/1c5c6RM

Glatthorn, A. A., Boschee, F., Whitehead, B. M., \& Boschee, B. F. (2012). Curriculum leadership: Strategies for development and implementation $\left(3^{\text {rd }}\right.$ ed.). Thousand Oaks, CA: Sage Publishing.

Gubrium, J. F., \& Holstein, J. A. (2001). Handbook of interview research: Context and method. Thousand Oaks, CA: Sage.

Gyuroka, T. (2016). What do pastors in German-speaking Europe perceive as important leadership competencies in order to be effective pastoral leaders? (Doctoral dissertation). Available from Andrews University.

Hebert, T. L. (2010). Assessing readiness for ministry of graduating students at Dallas Theological Seminary from selected profiles of ministry personal characteristics criteria (Doctoral dissertation). Available from Dallas Theological Seminary.

Henscheid, J. M. (2008). Preparing seniors for life after college. About Campus, November/December, 20-25. http://dx.doi.org/10.1002/abc.267

Hess, L. M. (2008). Formation in the worlds of theological education: Moving from "what" to "how." Teaching Theology and Religion, 11(1), 14-23. http://dx.doi.org/10.1111/j.1467-9647.2007.00392.x

Higgins, B. (2008). Program evaluation: Utilizing graduate and employer perception data in determining graduates' job preparedness levels. Journal of Industrial Technology, 24(3). Retrieved from www.nait.org.

Hollingsworth, Jr., J. N. (2008). Christian leadership coaching: Implications of postgraduate pastoral residencies for the mentoring curriculum at the McAfee School of Theology (Doctoral dissertation). Available from ProQuest Dissertations \& Theses. (UMI No. 3304643).

Holsti, O. R. (1969). Content analysis for the social sciences and humanities. Reading, MA: Addison-Wesley.

Howell, D. C. (2010). Statistical methods for psychology ( $7^{\text {th }}$ ed.). Belmont, CA: Cengage Wadsworth.

IBM Knowledge Center. (2011). Estimation methods for replacing missing values. Retrieved from https://ibm.co/2AI6s6D 
Kelsey, D. H. (1993). Between Athens and Berlin: The theological education debate. Grand Rapids, MI: Eerdmans Publishing

Kemp, S. (2010). Situated learning: Optimizing experiential learning through God-given learning community. Christian Education Journal, 7(1), 118-143. Retrieved from http://journals.biola.edu/cej

Kerlinger, F. N., \& Lee, H. B. (1999). Foundations of behavioral research $\left(4^{\text {th }}\right.$ ed.). Belmont, CA: Wadsworth Publishing

Kirkpatrick, D. L., \& Kirkpatrick, J. D. (2006). Evaluating training programs: The four levels ( ${ }^{\text {rd }}$ ed.). San Francisco, CA: Berrett-Koehler Publishers, Inc.

Koepke, D. (2011). Looking backward: Demonstrated clergy training needs. Journal of Religion, Spirituality \& Aging, 23, 18-32. http://dx.doi.org/ $10.1080 / 15528030.2011 .533360$

Kohl, M. W. (2006). Radical transformation in preparation for ministry. International Congregational Journal, 6(1), 39-51.

Kolb, D. (1984). Experiential learning: Experience as the source of learning and development. Englewood Cliffs, NJ: Prentice-Hall.

Landrum, R. E., Hettich, P. I., \& Wilner, A. (2010). Alumni perception of workforce readiness. Teaching of Psychology, 37(2), 97-106. http://dx.doi.org/10.1080/00986281003626912

LaRue, Jr., J. C. (1995). Profile of today's pastor: Ministry preparation. Your Church, 41(2), 56.

Lewis, J. G. (2000). The involvement and impact of the local church in the professional socialization of pastors (Doctoral dissertation). Available from Bell \& Howell Information and Learning Company. (UMI No. 9978101).

Lifeway Research. (March 22, 2010). Pastors still value, use seminary education. The Christian Post, Church \& Ministry. Retrieved from http://bit.ly/2B6Maqg

Lotz, D. W. (1977). Preparation for proclamation: Reflections on undergraduate theological education for ministry. Currents in Theology and Mission, 4(2), 7686. Retrieved from currentsjournal.org

Marsh, H. W. (1987). Student's evaluations of university teaching: Research findings, methodological issues, and directions for future research. International Journal of Educational Research, 11, 255-288. 
Martin, A. J., Milne-Home, J., Barrett, J., Spalding, E., \& Jones, G. (2000). Graduate satisfaction with university and perceived employment preparation. Journal of Education and Work, 13(2), 199-213. http://dx.doi.org/10.1080/713676986

McDowell, C. (1977). Relevant training: No longer in Kansas. Focal Point, 17(1), 5.

McKinney, L. J. (August, 2003). Evangelical theological education: Implementing our own agenda. Paper presented at the ICETE International Consultation for Theological Educators, High Wycombe, UK. Retrieved from http://bit.ly/2jgh4FF

McKinsey \& Company. (2013). Voice of the Graduate [White paper]. Retrieved from http://mckinseyonsociety.com/voice-of-the-graduate/

McMillan, J. H., \& Schumacher, S. (2010). Research in education: Evidence-based inquiry (7th ed.). Boston, MA: Pearson.

McNeil, K., Newman, I., \& Kelly, F. (1996). Testing research hypotheses with the general linear model. Carbondale, IL: Southern Illinois University Press.

Mead, L. B. (2005). The historic change in continuing education of church professionals. The Clergy Journal, 82(1), 3-5.

Meadville Lombard Theological School [Meadville]. (2011). Teaching Pastor Handbook, October 2011 revision. Retrieved from http://bit.ly/2iL7Mxm

Morgan, G. A. \& Shim, S. (1990). University student satisfaction: Implications for department planning. Home Economics Research Journal, 19(1), 47-66. http://dx.doi.org/10.1177/1077727X9001900106

Neuendorf, K. A. (2002). The content analysis guidebook. Thousand Oaks, CA: Sage.

Newman, I., Benz, C., Weis, D., \& McNeil, K. (1997). Theses and dissertations: A guide to writing in the social and physical sciences. New York, NY: University Press of America.

Newman, I., Lim, J., \& Pineda, F. (2013). Content validity using a mixed methods approach: Its application and development through the use of a table of specifications methodology. Journal of Mixed Methods Research, 7(3), 243-260. http://dx.doi.org/10.1177/1558689813476922

Newman, I., \& McNeil, K. A. (1998). Conducting survey research in the social sciences. Lanham, MD: University Press of America.

Newman, I., Newman, C., Brown, R., \& McNeeley, S. (2006). Conceptual statistics for beginners ( $3^{\text {rd }}$ ed.). Lanham, MD: University Press of America, Inc. 
Niebuhr, R. N., Williams, D. D., \& Gustafson, J, M. (1957). The advancement of theological education. New York, NY: Harper.

North American Division of the General Conference of Seventh-day Adventists. (20152016). Working Policy. Section L: The ministry and ministerial training. Nampa, ID: Pacific Press Publishing Association.

North American Division Ministerial Department. (2014, September). Pathways to effective pastoral ministry: A proposal for a fully integrated growth \& development journey from call to culmination. Presentation at a Strategic Summit, Berrien Springs, MI.

Osborne, J. W., \& Overbay, A. (2004). The power of outliers (and why researchers should always check for them). Practical Assessment, Research \& Evaluation, 9(6). Retrieved from http://PAREonline.net

Patterson, W. M. (1980). Changing preparation for changing ministry. Baptist History and Heritage, 15(1), 14-22, 59.

Rogers, K. H. (1956). Preparation for an effective pastoral ministry. Journal of Pastoral Care, 10(3), 161-169. Retrieved from http://www.jpcp.org/j_past_theol.htm

Rowdon, H. H. (1971). Theological education in historical perspective. Vox Evangelica, 7, 75-87.

Saperstein, M. (2006). Preparing rabbis for the future. European Judaism, 39(2), 146151. http://dx.doi.org/10.3167/001430006780586453

Shell, P. (1984). A study of selected variables dealing with continuing education interests of Seventh-day Adventist pastors and judicatory in the North American division (Unpublished doctoral thesis). Andrews University. Dissertation Abstracts DAI-A 45/06, 1706, Dec 1984.

Soper, D. (n.d.). Free A-priori sample size calculator for multiple regression. Retrieved from http://www.danielsoper.com/statcalc3/calc.aspx?id=1

Southern Adventist University. (2013). Undergraduate Catalog: 2013-2014. Retrieved from http://catalog.e.southern.edu/index.php?catoid=7

Southern Adventist University. (2015). Undergraduate Catalog: 2015-2016. Retrieved from http://catalog.e.southern.edu/index.php?catoid=11

Stone, C., Van Horn, C., \& Zukin, C. (2012). Chasing the American dream: Recent college graduates and the Great Recession [White paper]. John J. Heldrich Center for Workforce Development, Rutgers University. Retrieved from http://www.heldrich.rutgers.edu 
Tashakkori, A., \& Newman, I. (2010). Mixed methods. In B. McGraw, E. Baker, \& P. Peterson (Eds), International encyclopedia of education, ( $3^{\text {rd }} \mathrm{ed}$.). Oxford, England: Elsevier, Ltd.

Tashakkori, A., \& Teddlie, C. (2008). Foundations of mixed methods research: Integrating quantitative and qualitative techniques in the social and behavioral sciences. London, England: SAGE.

Trinkleim, D. H., \& Wells, J. A. (1989). Use of alumni survey in curriculum development. NACTA Journal, June Issue, 21-25. Retrieved from http://www.nactateachers.org/journal.html

Tryon, B. (2001). The implementation and evaluation of a leadership mentoring program in the Hampden Heights Seventh-day Adventist church (Doctoral Dissertation). Available from Andrews University. (UMI Number: 3096503).

U.S. Department of Education. (2006). A test of leadership: Charting the future of U.S. higher education. Retrieved from www.ed.gov

Vail, M. W. (2008). The challenge of evaluating clergy education in the context of the church of the Nazarene. Retrieved from http://www.didache.nazarene.org.

Weeks, L. B. (n.d.). Traditions and transformation: The educating clergy study and outcomes for theological education. Resources for American Christianity. Retrieved from http://www.resourcingchristianty.org

Wong, A. (2009). How do pastors connect their academic learning with their pastoral practice? Negotiating the tension between theory and practice. Practical Theology 2(2), 241-252. http://dx.doi.org/10.1558/prth.v2i2.241 
VITA

\section{Barry J. Tryon}

bjtryon@gmail.com

\section{Education}

2018

Doctorate of Philosophy

Leadership

Andrews University, Berrien Springs, MI

Dissertation Title: Measuring the perceived effectiveness of five selected professional courses taken by alumni theology majors and how they are related to selective demographics: A mixed methods study

$2000 \quad$ Doctorate of Ministry Andrews University, Berrien Springs, MI

Dissertation Title: The implementation and evaluation of a leadership mentoring program in the Hampden Heights Seventh-day Adventist church

1985 Master of Divinity Andrews University, Berrien Springs, MI

$1982 \quad$ B.A. Theology

Southern Adventist University, Collegedale, TN

\section{Professional}

2013-Present

$2011-2013$

2003-2010

1989-2003

$1985-1988$
Professor

Southern Adventist University, Collegedale, TN

Associate Professor

Southern Adventist University, Collegedale, TN

Conference Secretary/Ministerial Director

Pennsylvania Conference of Seventh-day Adventist

Reading, PA

Pastor

Pennsylvania Conference of Seventh-day Adventist

Pastor

Florida Conference of Seventh-day Adventist 